\title{
مدينة الرباط
}

"دراست تحليليت لبعض خصائص التركيب العمرانى والسكانى"

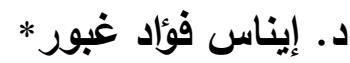

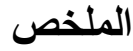

تسعى دراسة الحيز الحضرى وتحليل مكوناته إلى فهم ورصد إمكانية التخطيط لتحقيق تجانس

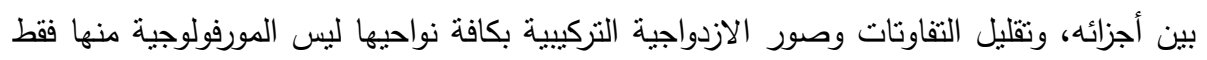

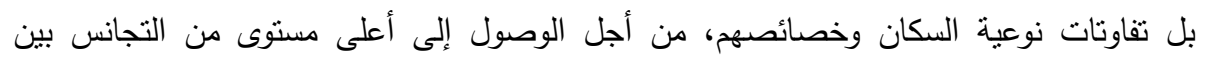
مختلف قطاعات المدينة وإيجاد بيئة حضرية مستدامة. وتهدف الدراسة إلى رصد مدى التثابه والاختلاف بين الأفسام الإدارية الكبرى لمدينة الرباط طبقاً

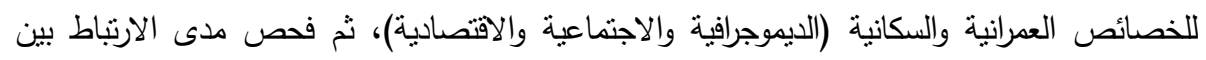
مجموعة الخصائص السكانية وانعكاساتها على البيئة الحضرية من خلا فحص الخصائه الخصائص العمرانية،

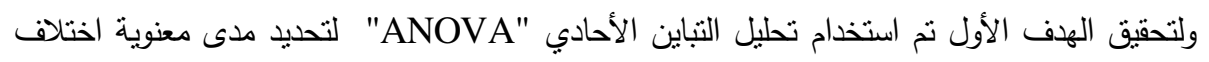

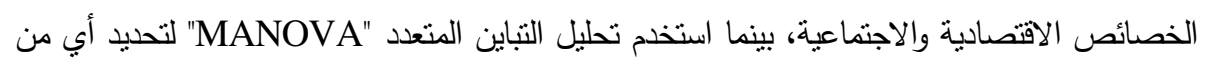
الخصائص الاقتصادية والاجتماعية تربطها علاقة مع واحد أو أكثر من الخصائص الإينم العمرانية.

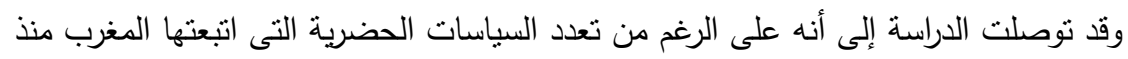

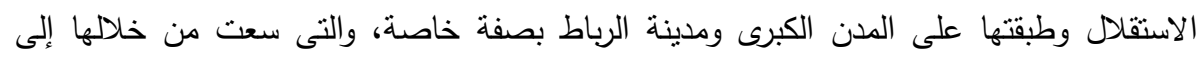

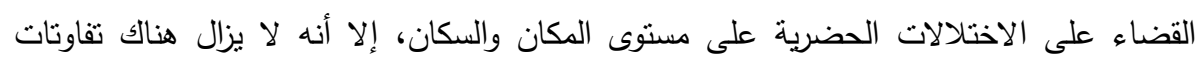

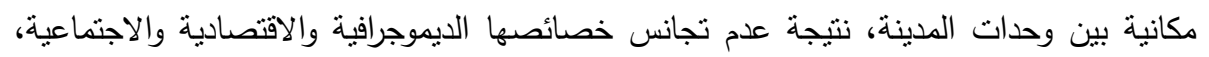

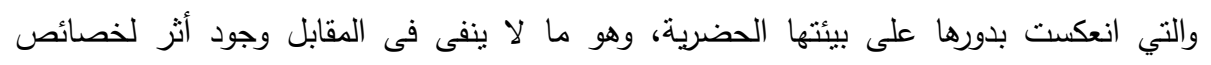

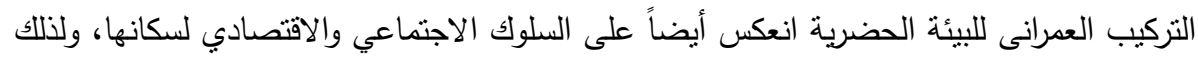

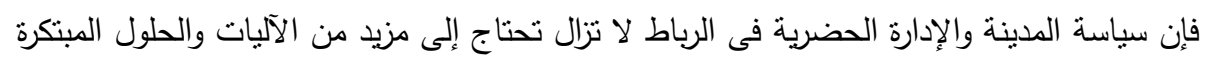

$$
\text { التى تركز على الجوانب والقضايا الاجتماعية. }
$$

الكلمات الاالة: الخصائص العمرانية الاجتماعية والاقتصادية، تحليل التباين الأحادى، التباين

$$
\text { المتعدد، التجزئة الحضرية. }
$$

$$
\text { * مدرس الجغرافيا البشرية (عمران حضرى)، معهد البحوث والدراسات الافريقية - جامعة القاهرة. }
$$


يمكن النظر إلى تركيب المدينة الداخلى من زاويتين الأولى مادية تنصل بمورفولوجية المدينة وأبعادها المختلفة، والأخرى زاوية اجتماعية حضارية تتصل بالسكان ومؤشراتهم الاقتصادية والاجتماعية

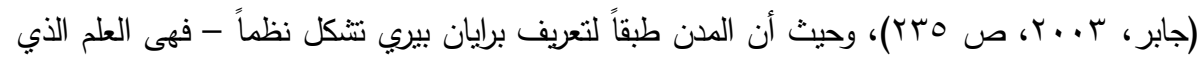

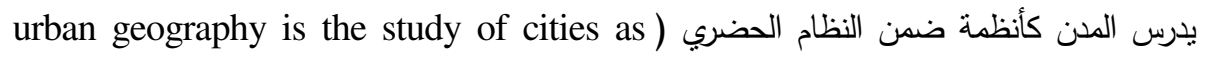
(systems within a system of cities التراكيب المتنلفة فى المدينة، على أساس أنها تنكل نظاماً city as system بهدف إبراز أوجه التشابه والاختلاف "التباين الككاني Areal Differentiation" للوصول إلى قوانين أو تعميمات، يمكن بواسطتها

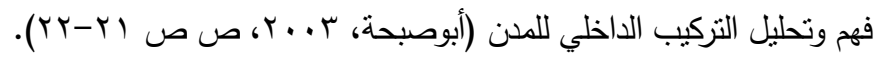

\section{أهمية الدراسة وأسبابها :}

تمثل دراسة طبيعة تركيب السكان وخصائصهم في المناطق الحضرية أحد أهم جوانب دراسة

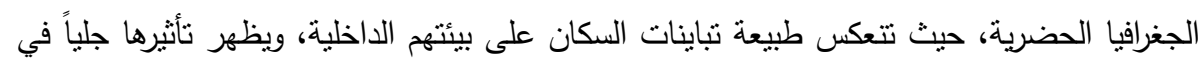
التأثير على التركيب الوظيفي للمدينة، فقد أثنتت العديد من الدراسات للمدن الغربية العلاقة الارتباطية

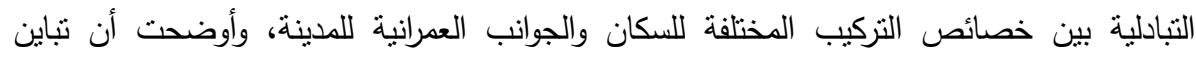
الخصائص الاجتماعية للمدينة الغربية ينعكس بدوره على المناطق السكنية، والتي بدورها تتعكس ولتهن

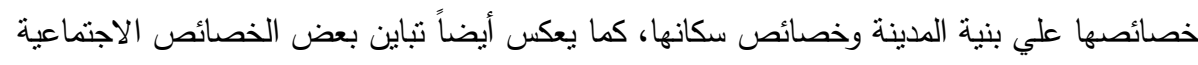

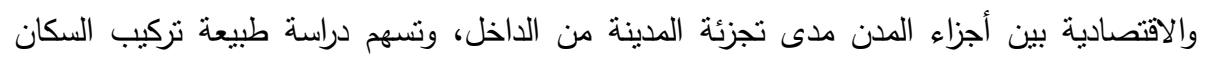

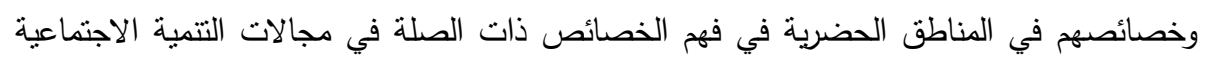
والاقتصادية، لذا فهى تقيد في جوانب التخطيط الحضرى ووضع تصور عن فئ طبيعة الخدمات

المتخصصة التي من المفترض أن توفرها المدينة (Johnson, 1972, 47, 48, 51).

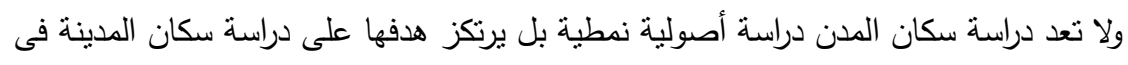

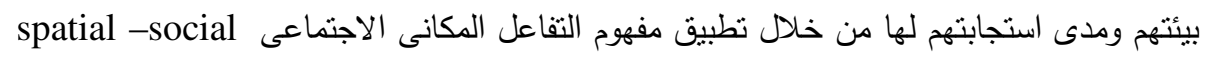
interaction

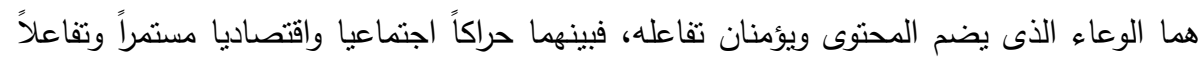

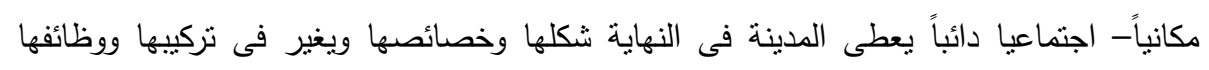

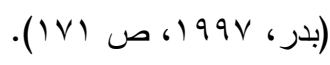
وتتسم مدن العالم الثالث ومن بينها إفريقيا على وجه الخصوص بسمات فريدة أهمها

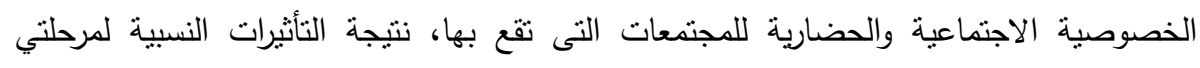

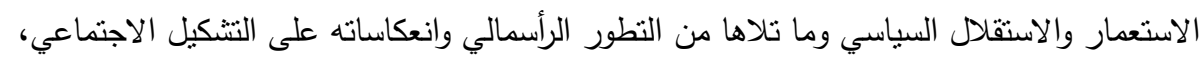


وهو ما نتج عنه غياب نموذج موحد يميز النسق الحضرى لتلك المدن، حيث أن مناطقها الحضرية ظواهر لا يمكن فلك شفرتها بشكل مستقل عن العوامل الاقتصادية والتحولات الإيديولوجية والسياسية وصراع الطبقات ... إلخ (Chatterjee, 1989, p. 127). كما تتسم مدن العالم الثالث بكونها مجزئة وغير متجانسة ولا يقتصر عدم تجانسها على الشكل

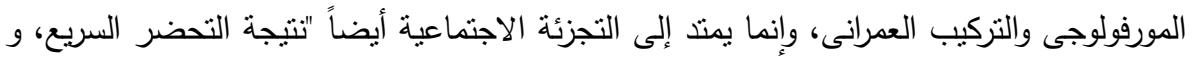

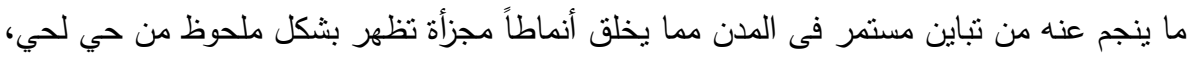

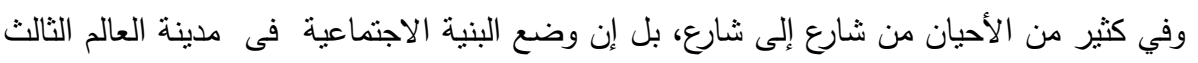

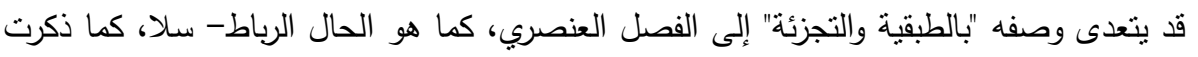

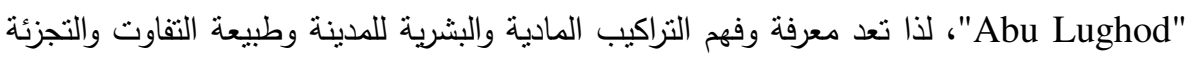
المكانية Spatial inequalities \& spatial fragmentation أمراً ضرورياً لعمليات تخطيط وفئة الحيز الحضري والإدارة الحضرية، بهدف تقليل التفاوتات ومواكبة التحولات الديموجرافية والاقتصادية والعمرانية التى نتهدها المدن (Balbo, 1993, p. 40). تحظى مدينة الرباط عاصمة المغرب طبقاً للعديد من المؤشرات الإحصائية الرسمية بتتوع ثقافي وديموغرافي واجتماعي واقتصادي، مما يجعلها

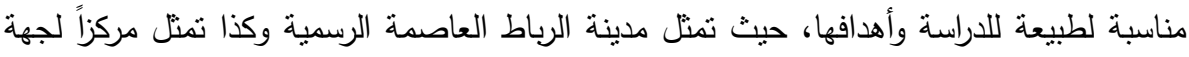

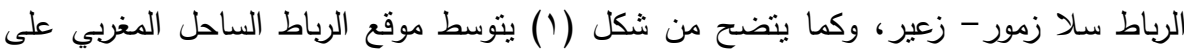

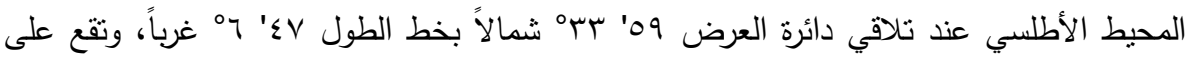

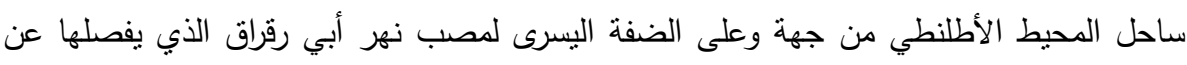

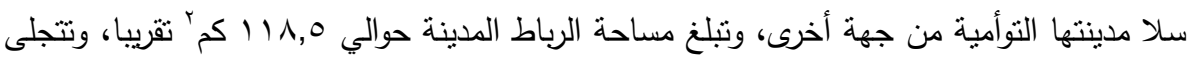
قيمة موقع المدينة فى مركزها المتوسط بين الثمال والجنوب، وفى موضعها السهلى فى منطقة سهلية ضيقة مثلت طريق مرور بين الثمال والجنوب على مر الفترات التاريخية.

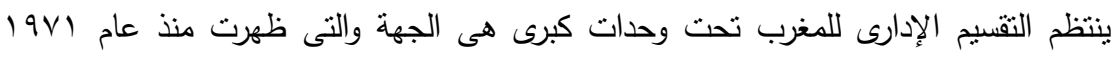

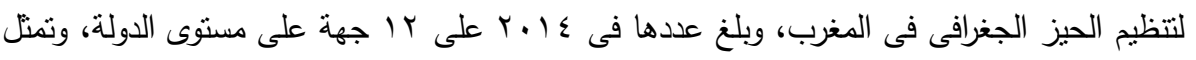

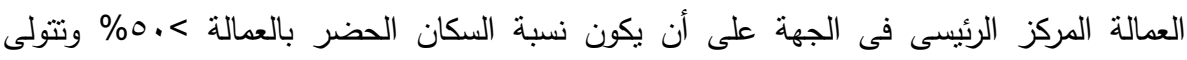

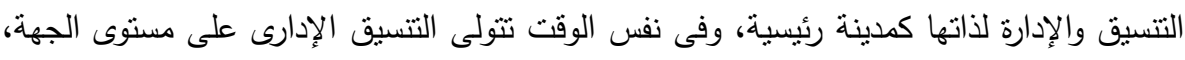

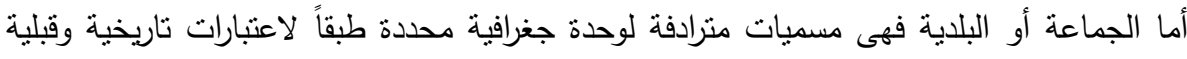

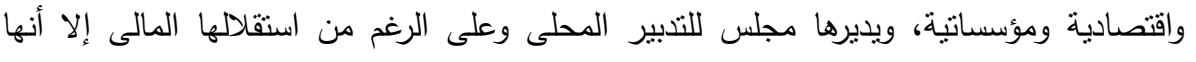

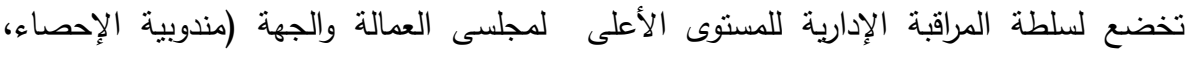

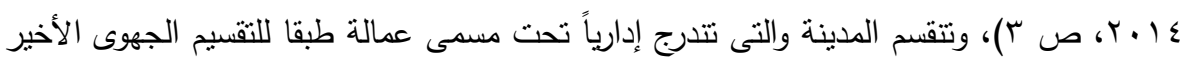

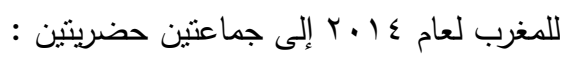




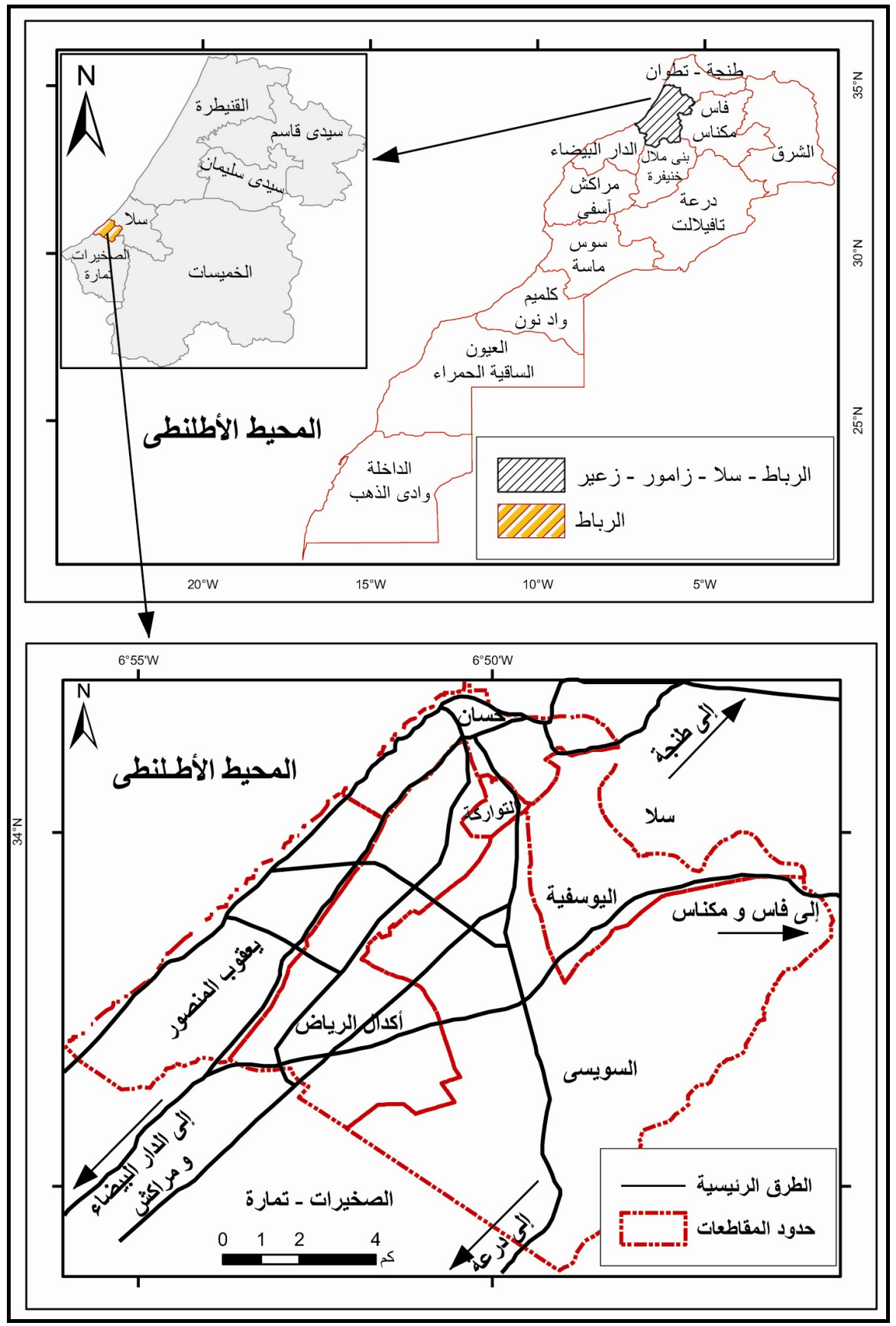

شكل (1) : موقع مدينة الرباط، والتقسيم الإدارى للمدينة طبقا لتعداد عام ع ا ـr. المصدر: بتصرف اعتمادا على: المندوبية السامية للتخطيط http://rgphentableaux.hcp.ma/Default1 (ابريل 17 • r) 鼻 V $\mathrm{A}$ 


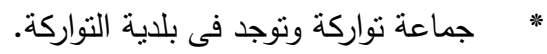

جماعة الرباط : المكونة من خمس مقاطعات (الرباط، حسان، أكدال، الرياض، اليوسفية، يعقوب المنصور والسويسي) (الوكالة الحضرية للرباط وسلا، (aurs.org.ma/ar/info).

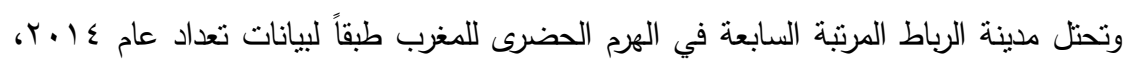

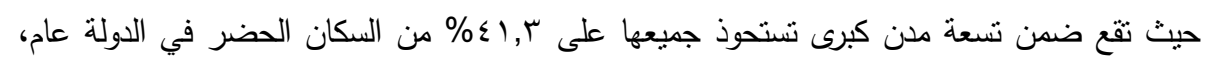

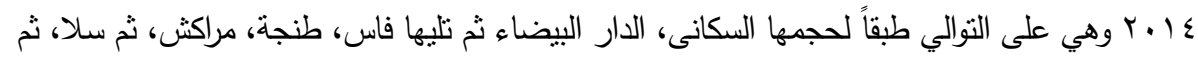

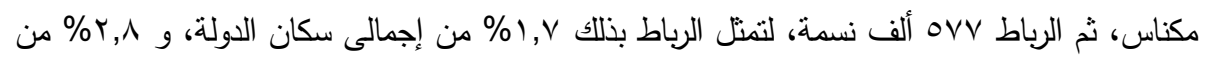

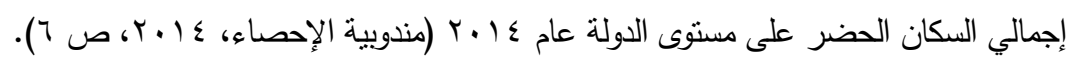

\section{الاراسات السابقة : الدات}

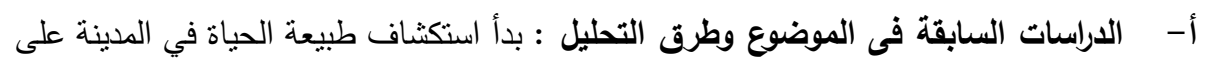

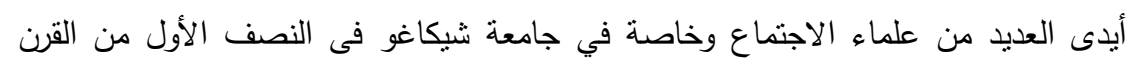

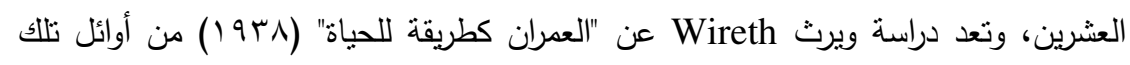

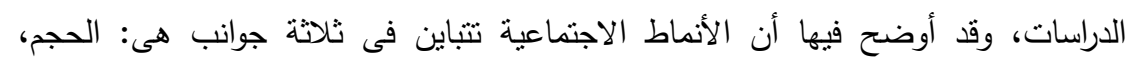
والكثافة، وعدم التجانس، والتى تربطها جميعها علاقة طردية مع المستوطنة العمرانية الكبيرة فى ذات الوقت (Urry, 1989, p. 295).

وقد ناقتت العديد من النظريات الجغرافية وأهمها النظريات الكلاسيكية الإيكولوجية الإنات

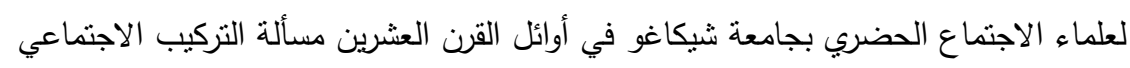

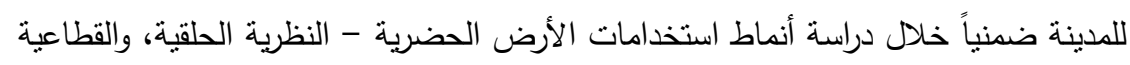

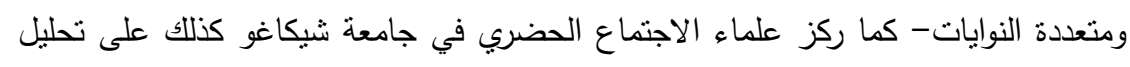

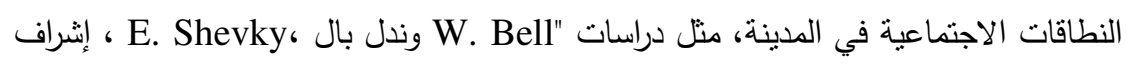
شيفكي"، وقد أجريت دراسات تحليل المنطقة الاجنماعية على مدن كثيرة في العالم المنقدم

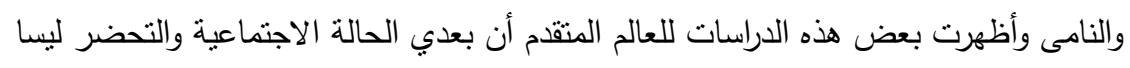

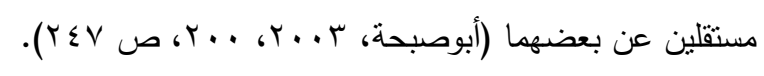

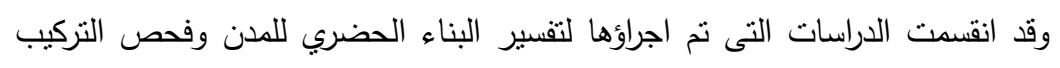

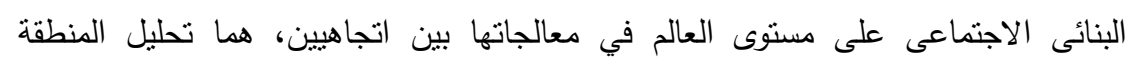

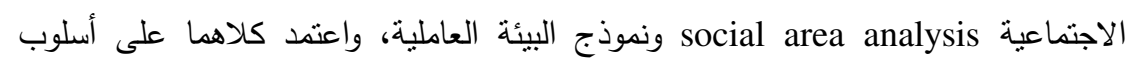

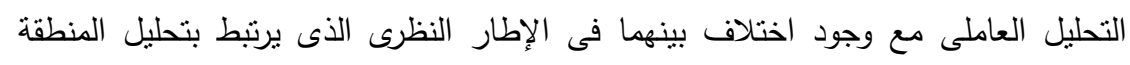

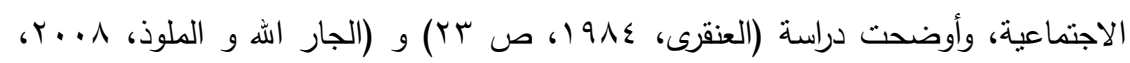


ص 9) أن الدراسات التى تمت لعدد من الددن فى دول العالم الثالث لم تؤد إلى وجود نموذج

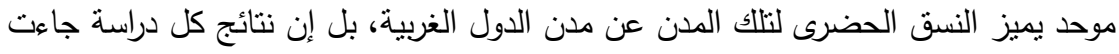
إلى حد ما متأثرة بالخصوصية الاجتماعية والحضارية لـجتمعاتها. كما اتجهت الدراسات إلى استخدام أساليب أخرى لمعالجة البيانات متعددة المتغيرات إضافة للتحليل العاملى، وهى أساليب حزمة Statistical Package For Social ) SPSS (Science

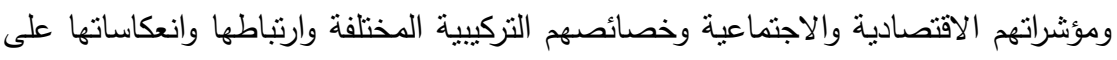

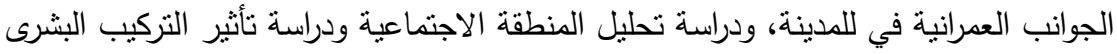

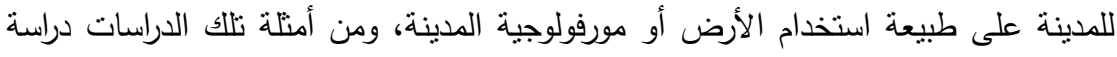
(Abdel-Azeem, 2013) والاجتماعبة لمدينة وادى النطرون معتمداً على أسلوب تحليل التباين متعدد المتغيرات، ودراسة الجية كل من (Sabina \& Ruiz, 2016) والتى عالجت تحليل العلاقات بين قياسات تجزئة استخدام الأرض فى المناطق الحضرية والمتغيرات الاجتماعية والاقتصادية منبعة أسلوبى التحليل العاملى والتحليل العنقودى، ودراسة (Boateng, et al., 2016) التحليل المقارن لإدارة

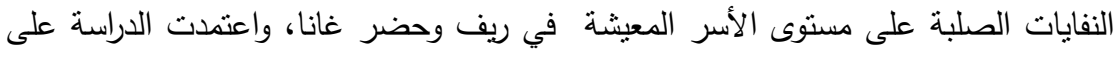

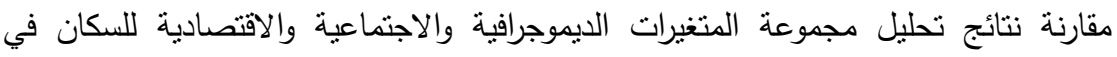

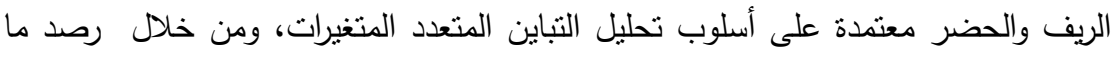

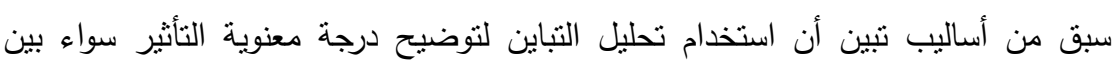

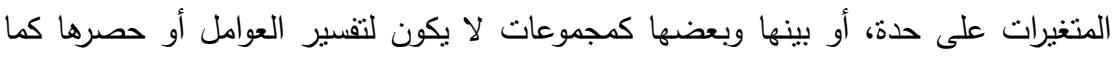

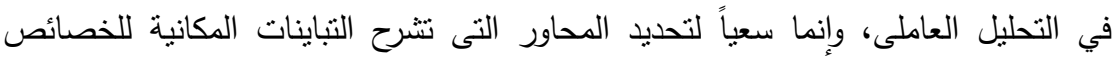
السكانية، وتفسير المظاهر المميزة للتنظيم الاجتماعي في المراكز الحضرية، وتأثنر الحياة الحضرية على الواقع الاجتماعي من جانب أخر . ب- الداسات السابقة في موضوع ومنطقة الاراسة: دراسة أبو لغد فى ع 9 البع ونتاولت التحليل المقارن للنظام الطبقى فى سلا والرباط بعد الاستعمار، معتمدة على استخدم أسلوب التهاب التحليل

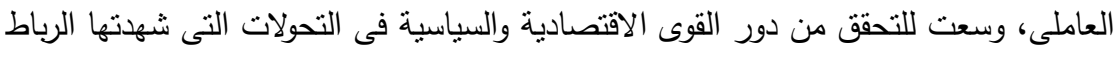

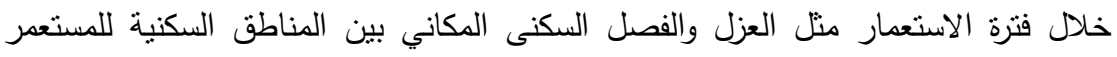

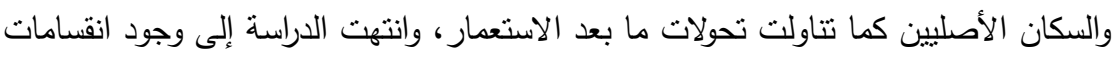

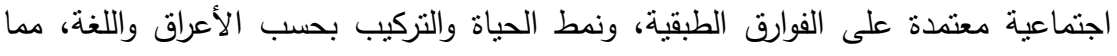
أمكن معه تمبيز ثلاثة أنماط من المدينة من حيث التركيب وخصائصده المادية و الحضارية -

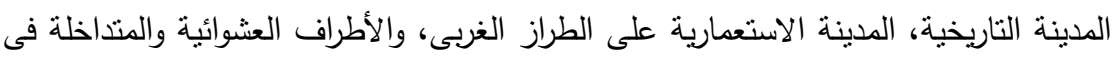


النسيج (Abu Lughod, 1975, pp. 21-23)، أما دراسة (Findlay \& Paddison, 1984) فقدمت تحليلاً لمدى نآكل المساحات السكنية أو المحافظة عليها وازدواجية التركيب فى الرباط وسلا بعد الاستعمار، بينما ناقثت دراسة (Balbo \& Bouchanine, 1995) التجزئة الحضرية للرباط وسلا، وناقثت الازدواجية المورفولوجية التركيبية للرباط وسلا نتيجة المؤثرات الوطنية والاستعمارية، منبعة منهاً وصفياً كغيرها من الدراسات التى تتاولت التركيب الاجتماعى فى الرباط باستثناء دراسة أبو لغد.

\section{أهداف الدراسة : أماسن}

1- التعرف على تباين التوزيع المكاني للجوانب العمرانية والخصائص الديموجرافية والاجتماعية والاقتصادية فى مدينه الرباط باستخدام أساليب تختزل قيم نتائج التباين كمياً.

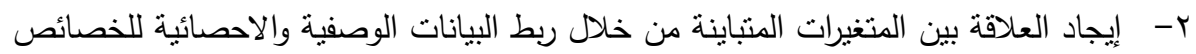
العمرانية والاقتصادية والاجتماعية مع البيانات المكانية.

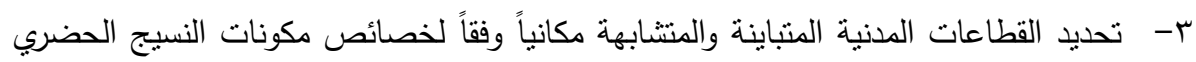
"العمرانية والاجتماعية والاقتصادية"، لتوفير قاعدة بيانات تحليله تساهم فى مجال تخطيط وفيط

$$
\text { وإدارة الحيز الحضري. }
$$

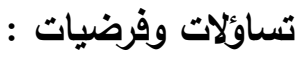

تسعى الدراسة إلى الإجابة عن عدة نساؤلات وهى إلى أى مدى نسود التجزئة الاجتماعية

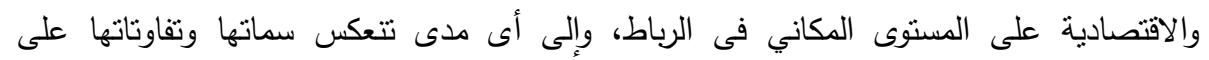

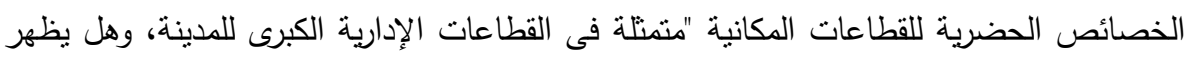

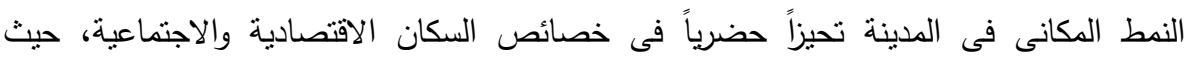

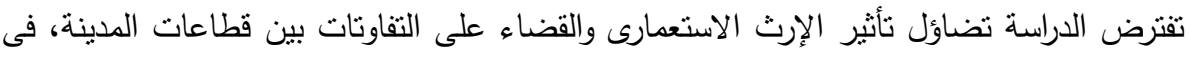

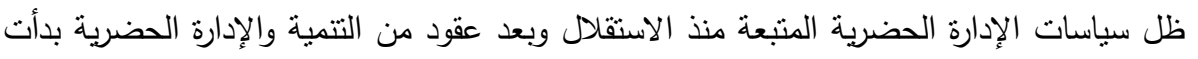

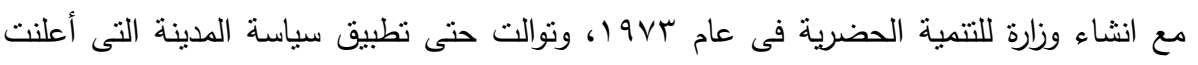

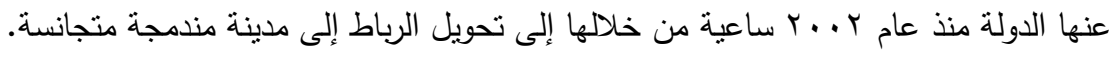

\section{المناهج والأساليب - ومصادر بيانات الدراسة :}

استخدمت الدراسة عدة مناهج وأساليب من أجل تحقيق أهدافها، وهى المنهج الوصفى التحليلى، وقد

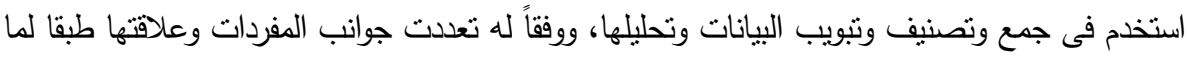

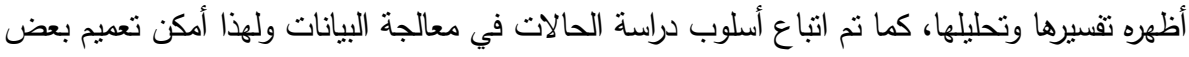


النتائج في الحالات التي تجمعها جوانب مشتركة، كما سيتضح عند دراسة الخصائص التوزيعية للمتغيرات

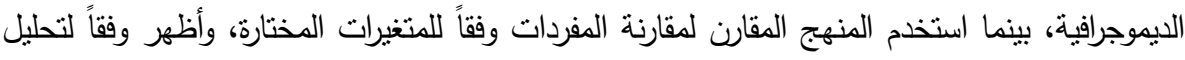

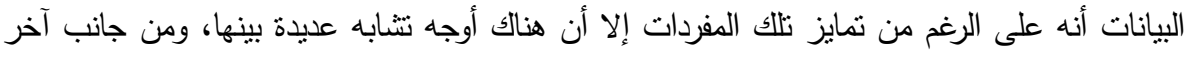

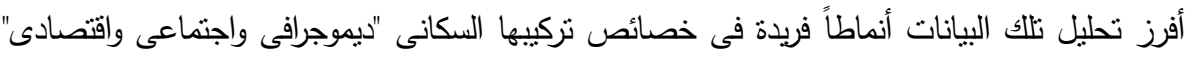

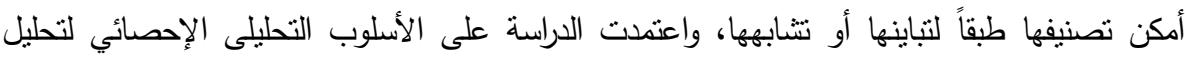

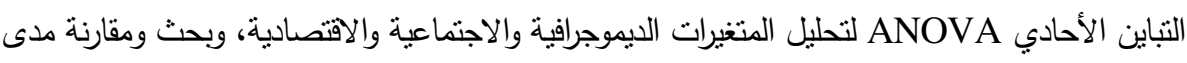

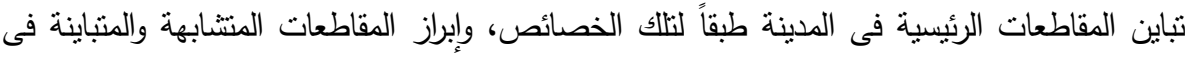

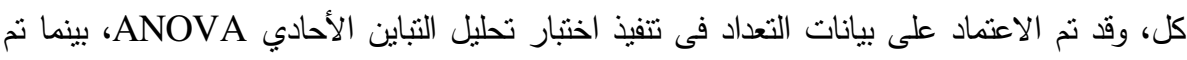
استخدام تحليل التباين المتعدد MANOVA لتحيد مدى معنوية تأثنير الخصائص الإديموجرافية

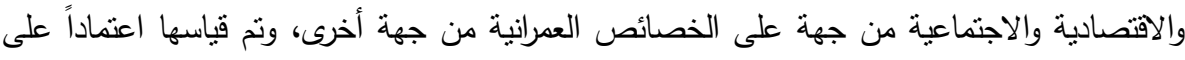
بيانات الاستبيان. كما استخدم أسلوب التمثيل الكارتوجرافى في معالجة البيانات الإحصائية وتحليلها واستخراج المؤشرات وتنبع دلالاتها وربطها وتعليلها.

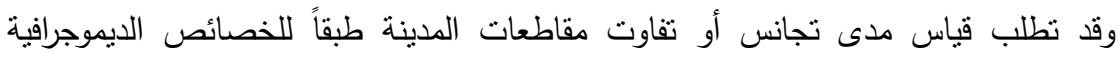

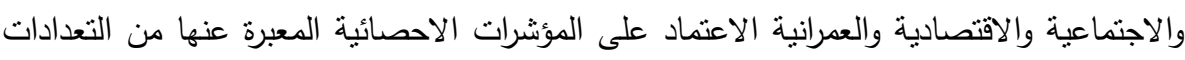

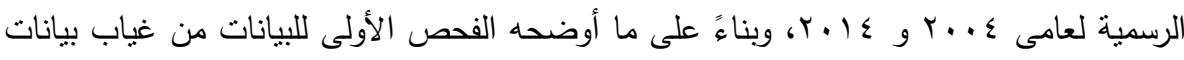

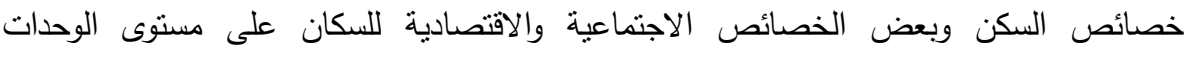
القطاعية داخل الددن، لجأت الدراسة إلى الاعتماد على الدراسة الميدانية وعناصرها من الاستبانة

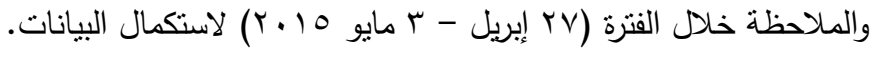

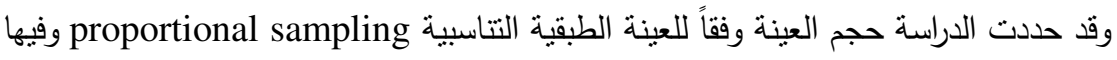

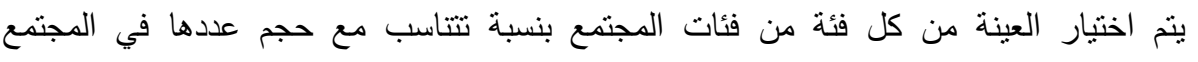

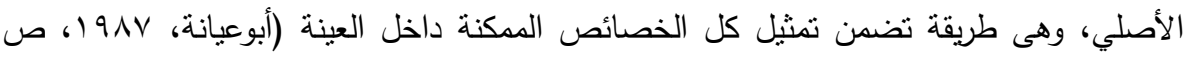
(ب)، وبما أنه لا توجد عينه مثالية فإن استخدام المعادلات الاحصائية لتحديد حجم العينة ينيح وجود مستوى ثقة فى العينة محل الاختيار وحساب نسبة الخطأ وفق معيار كمى هو فاصله

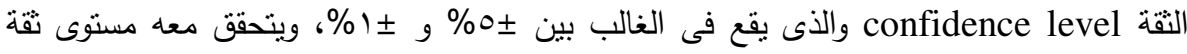
90\%، 99\% وقد تم اختيار حجم العينة وفقاً للمعادلة النالية :

$$
n=\frac{N}{1+N e^{2}}
$$

حيث n هو حجم العينة، N إجمالى حجم الأسر المعيشية على مستوى المدينة، و e هو مستوى من الدقة

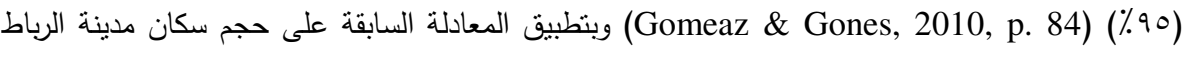

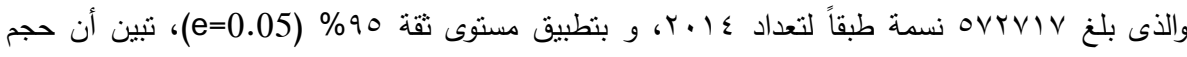
العينة المطلوب هو . . ـ ساكن. 


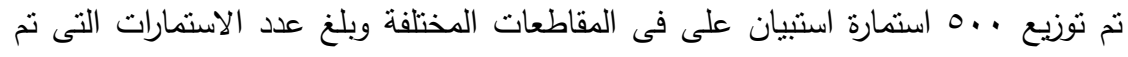

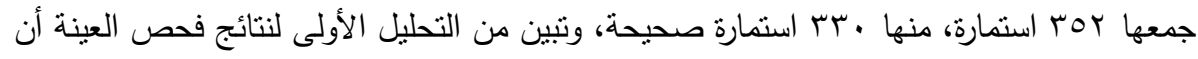

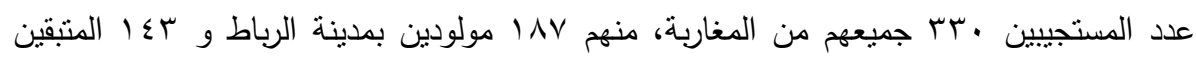
مولودين بمدينة أخرى، كما يتضح من بيانات الجدول رقم (1):

جدول (1) : نوزيع حجم العينة على مقاطعات مدينة الرباط.

\begin{tabular}{|c|c|c|c|c|}
\hline عدد الاستمارات & عدد الاستمارات & حجم العينة & ؛ ع & البيان \\
\hline 01 & TV & or & VYTOV & أكدال الرياض \\
\hline $7 \varepsilon$ & $1 \leqslant 1$ & 111 & $\mid v .071$ & اليوسفية \\
\hline$\varepsilon r$ & 94 & vo & $1.11 \vee 9$ & حسان \\
\hline 11 & $r$. & 17 & דצדיזי & السويسى \\
\hline . & $\varepsilon$ & $r$ & rqu & التواركة \\
\hline 10 & 171 & 1ro & $19 \leq 0 r r$ & يعقوب \\
\hline rr. & 0. & $\varepsilon \ldots$ & OVVAYV & الاجمالى \\
\hline
\end{tabular}

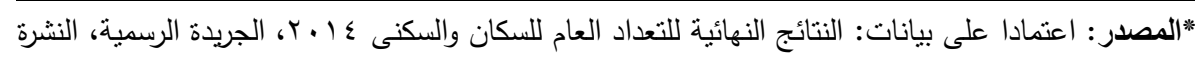

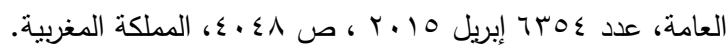

وتطبيق المعادلة رقم ( ) (Gomeaz \& Gones, 2010, p. 84).

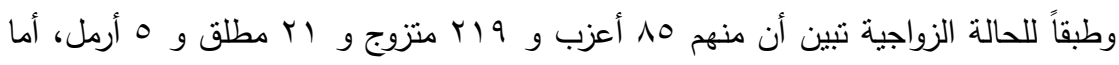

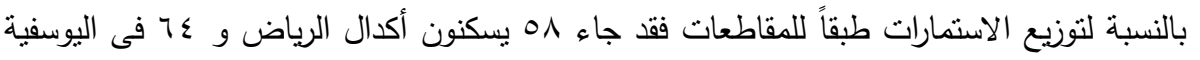

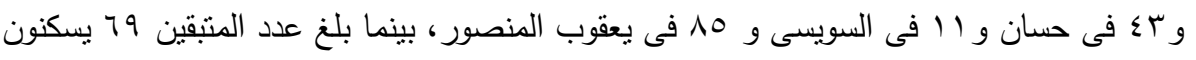

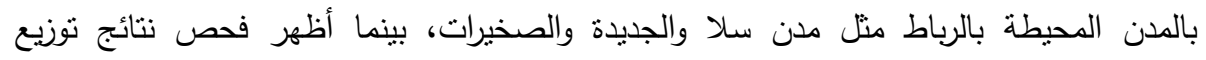

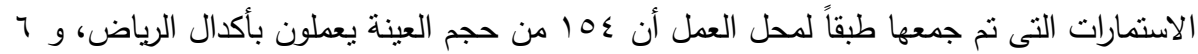

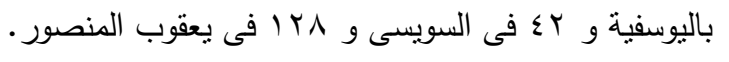


ثالثاً: تحليل التباين الأحادي لخصائص التركيب العمرانى والسكانى لمدينة الرباط.

لابعاً: تحليل التباين المتعدد لخصائص التركيب العمرانى والسكانى لمدينة الرباط.

خامساً: النتائج والتوصيات.

\section{أولاً - خصائص التركيب العهراني لمدينة الرباط :}

نشأت مدينة الرباط في القرن السابع عشر معتمدة على موقعها على الساحل الغربي للمغرب،

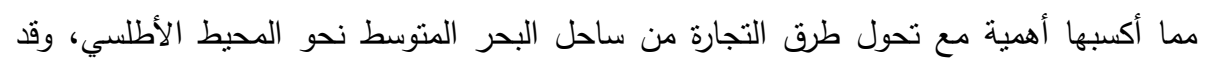

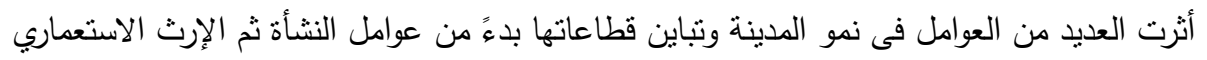
وما تلاه من سياسات التتمية بعد الاستقلال، وقد تعاظمت أهمية مدينة الرباط بحلول القرن الثامن عشر عندما نم اختبارها كنقطة استراحة منتظمة للسلطان في رحلته بين عواصم فاس ولند ومكناس ومراكش، وارتقت بعد ذللك المدينة لتصبح واحدة من أكبر وأهم أربع مدن وعاصمة للبلاد، بينما نمت فئت الأهمية السياسية للمدينة متزامنة مع وجود اتجاه قوي نحو تدويل الاقتصاد المغربي، مما ترتب عليه

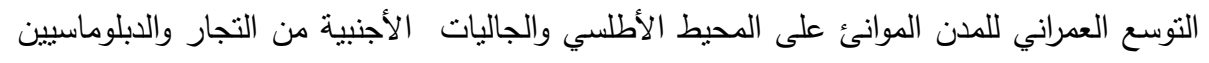

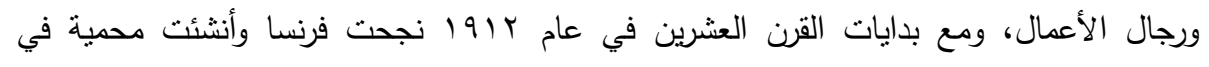

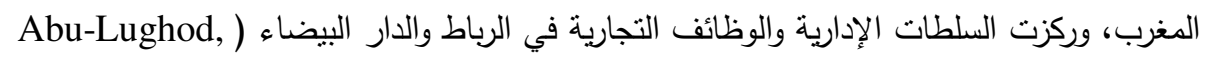
.(1975, pp. 21-23

وقد شهدت المدينة نوسعاً خلال الفترة الاستعمارية طبقاً لمخطط تم تتفيذه فى أواخر . . 1975

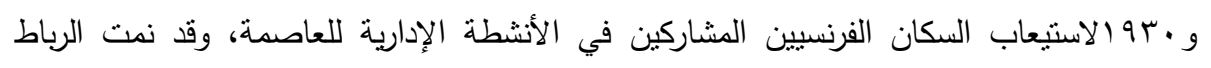

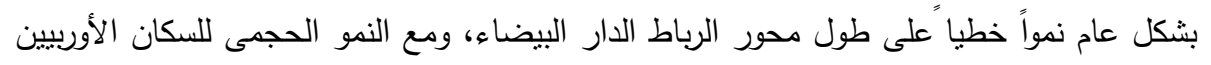

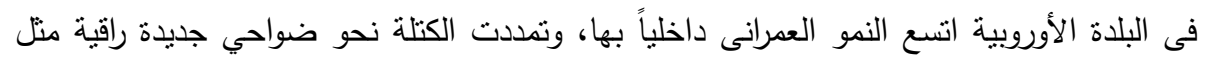

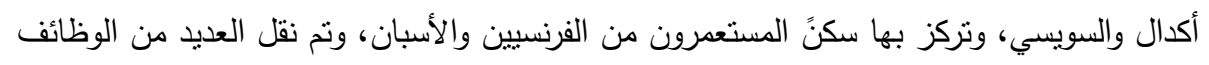

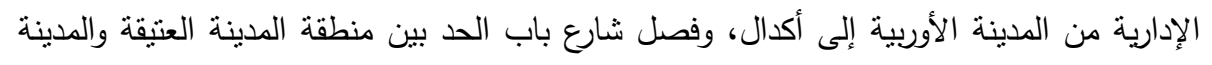
الأوربية الحديثة (Abu-Lughod, 1975, pp. 21-23). وتمثل كل من حسان واليوسفية والتواركة

$$
\text { حالياً المقاطعات الأقدم فى المدينة. }
$$

لعبت عوامل النمو الديموجرافى دوراً هاما فى نمو العمرانى للمدينة، فقد شهدت المنات المناطق

المبنية من الرباط نمواً سريعاً يرجع إلى حد كبير إلى النمو التراكمى فى المناطق السى السكنية الجديدة

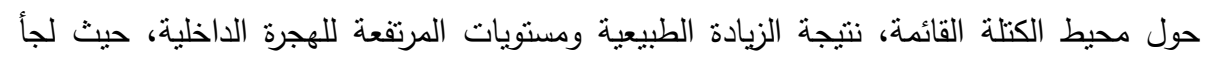

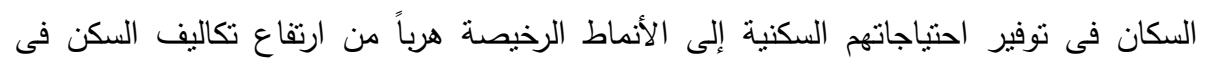
المنطقة المركزية فى القطاع الاوروبى واكتظاظها وقلة الفرص المتاحة (Balbo, 1993, p. 43). 
وقد تتامى الدور الوظيفى الإدارى والسياسى للمدينة بعد حصول المغرب على الاستقلال عام

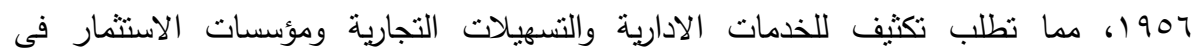
المقاطعات الحديثة "أكدال و السويسى"، وقد بدأ المغاربة المحليين من ذوى الدخل المرتفع من الرباط

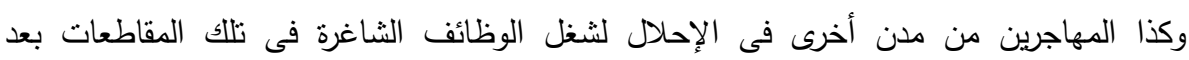

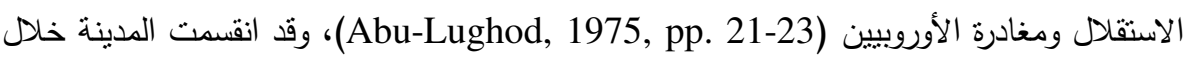
هذه الفترة إلى قطاعات ووحدات مورفولوجية متباينة مستمرة حتى الآن (شكل r ب).

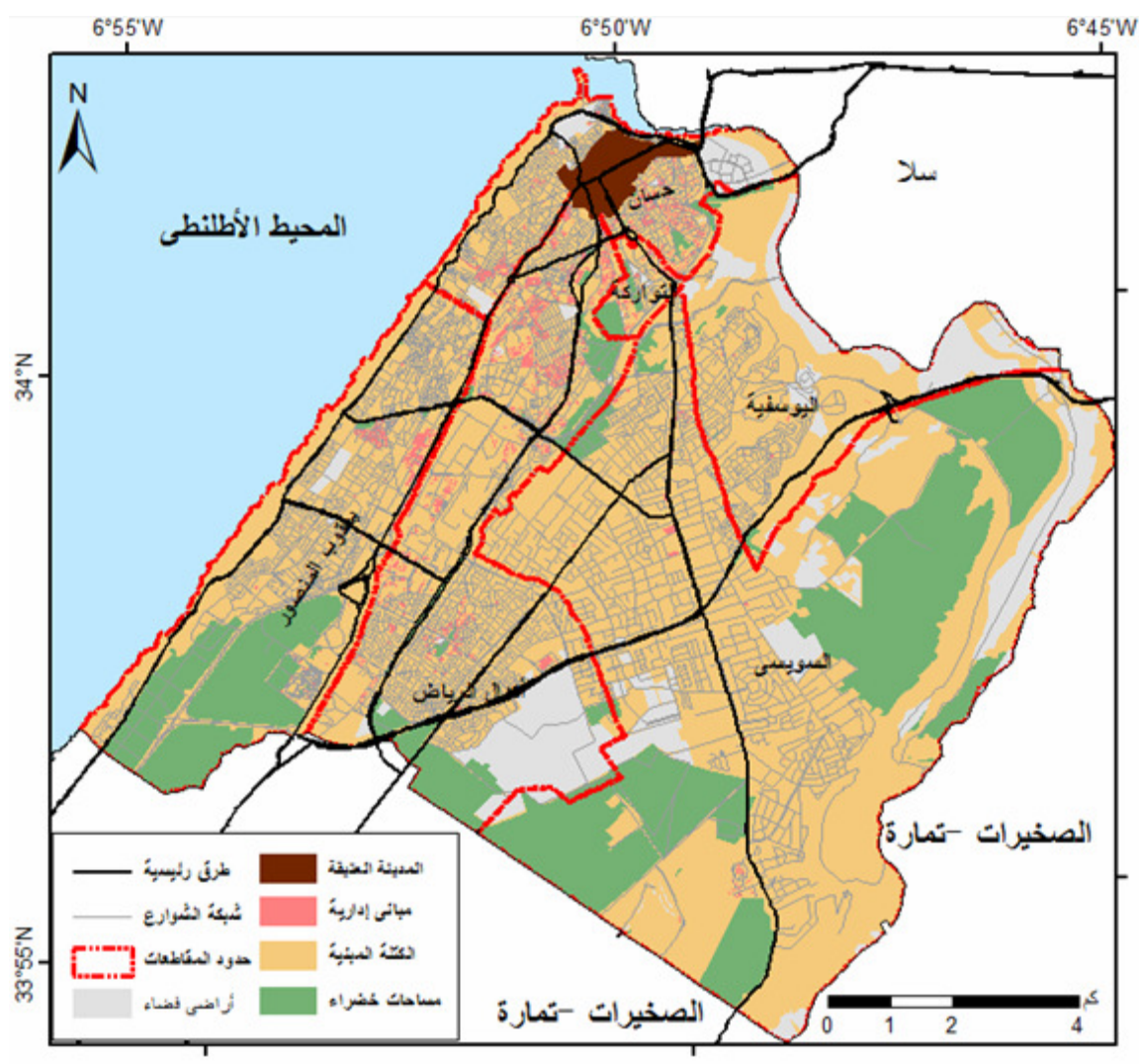

شكل (Y) : ملامح التركيب الحضرى لمدينة الرباط.

المصدر: بتصرف: اعتمادا على:

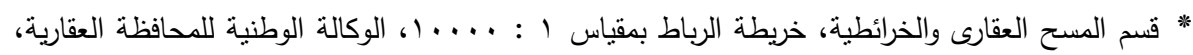

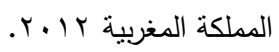

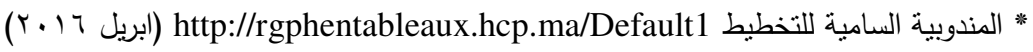
重1 100 
ويعكس نركيبها العمرانى سمات ميزتها عن غيرها، فعلى سبيل المثال مثلت المدينة العتيقة منطقة النواه للرباط بشبكة شوارعها العضوية ومساكنها ذات الطابق الواحد، بينما اتبعت المدينة

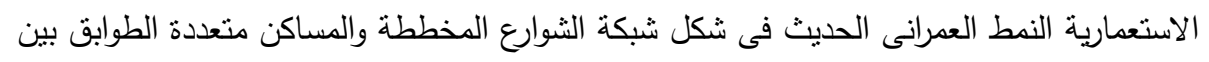

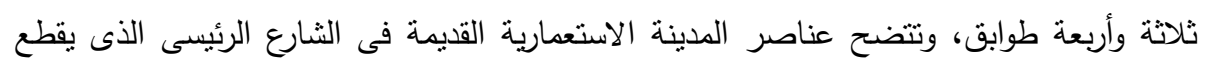
الرباط" شارع محمد الخامس"، وقد شهدت منطقة"المدينة العتيقة" حيث السكان المحليين نمواً سريعاً

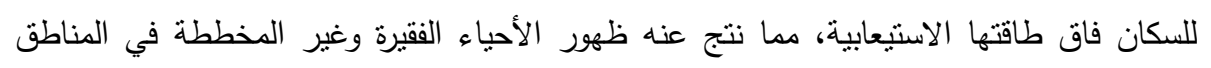
المتاخمة لها في مناطق عديدة مثل دور الدوم جنوب شرق الرباط على مقربة من مناطق الكثافة

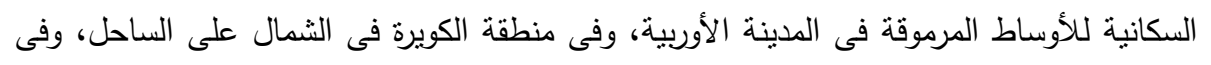

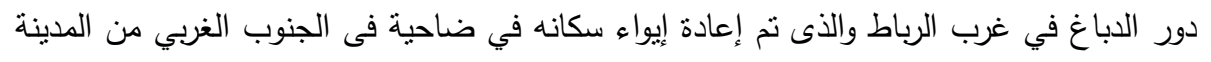

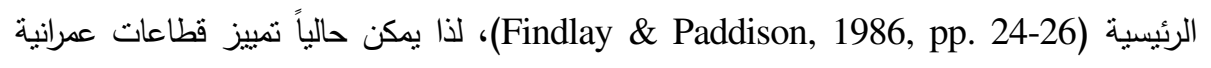

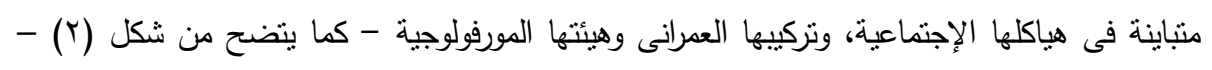

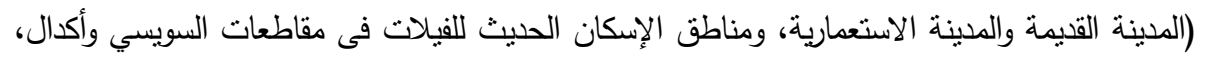
والأحياء والمستوطنات الفقيرة والعشوائية حول الكنلة القنيمة).

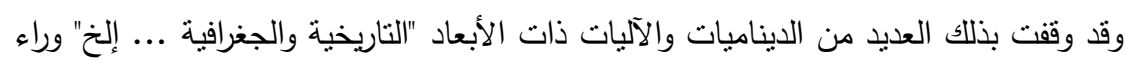

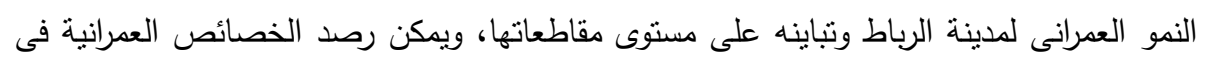

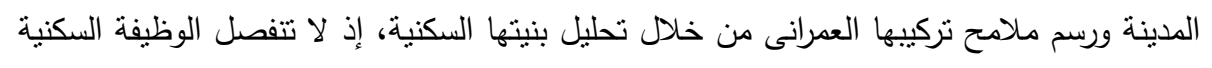

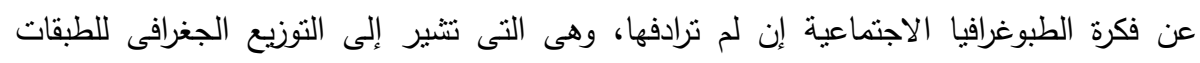

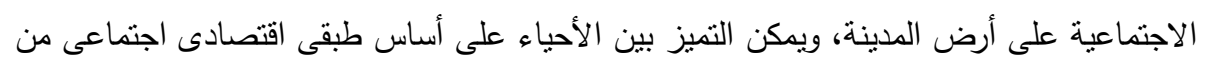

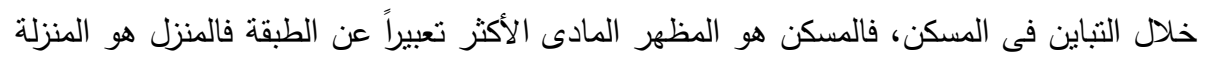

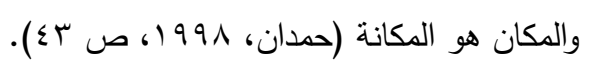

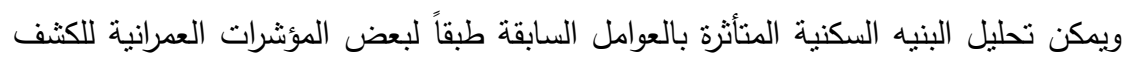

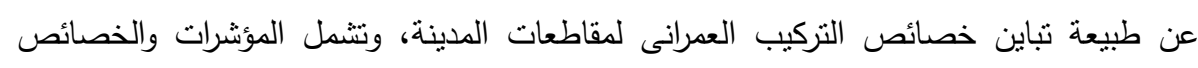

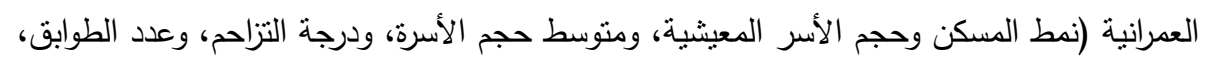
واستخدام الدور الأرضى، ونمط الإشغال وتجهيزات المسكن والإمداد بالخدمات الأساسية):

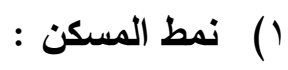

تنتوع أنماط المسكن فى الرباط طبقاً لما تظهره بيانات التعداد فى عام \& 1 ب ب بين (الفيلا والثقة والمسكن المستقل - "ويقصد به الدار الدغربية تقليدية أو حديثة" وأنماط أخرى)، ويشير لئير

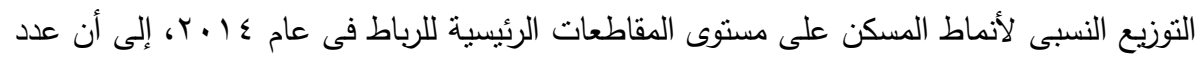

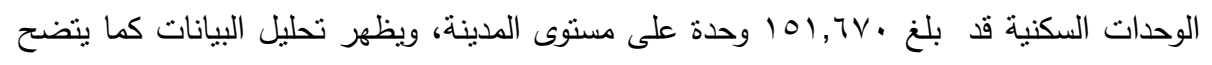




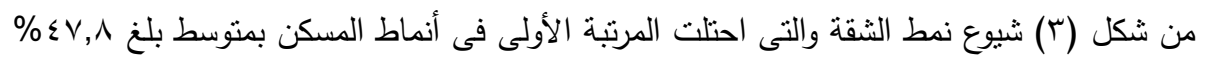

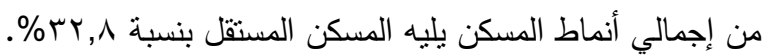

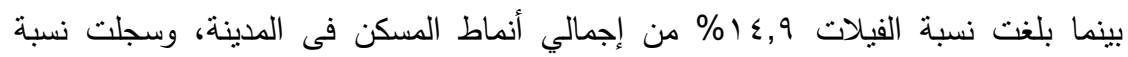

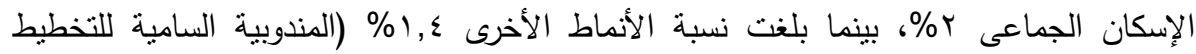

.(http://rgphentableaux.hcp.ma/Default1

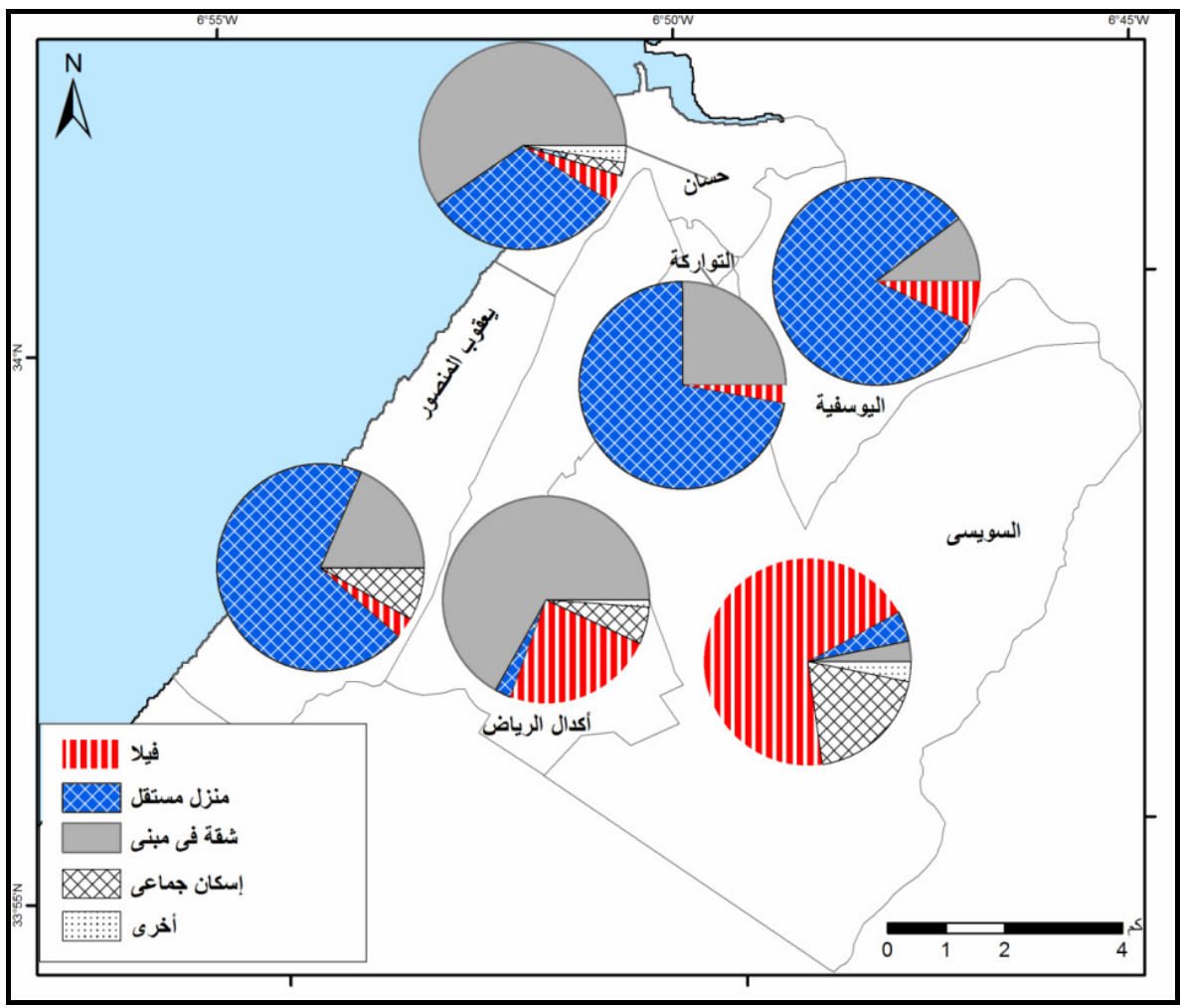

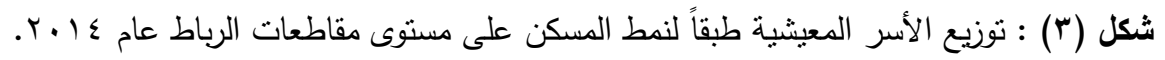

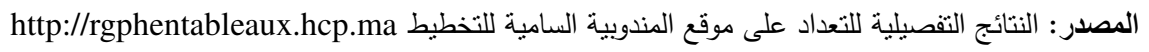

ويشير تحليل توزيع الأسر المعيشية طبقاً لأنماط المسكن على مستوى مقاطعات الرباط ، إلى

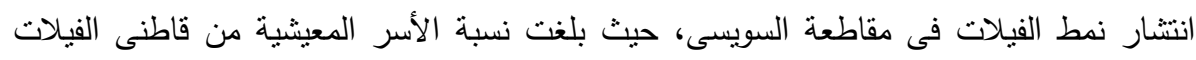

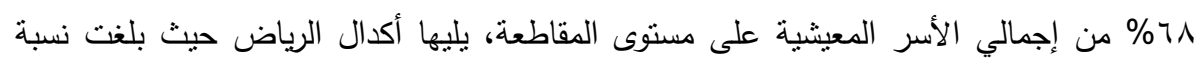

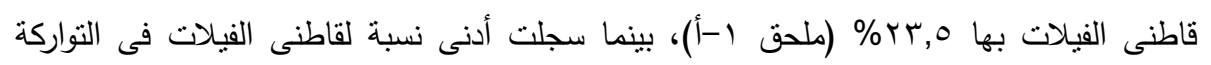




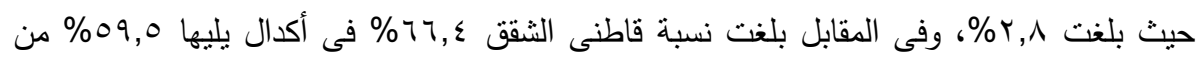

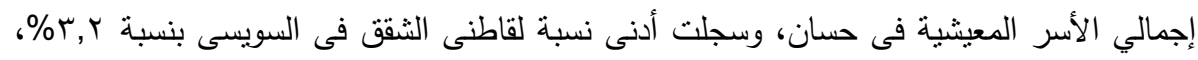

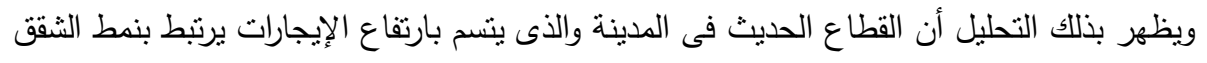
(ملحق ا-ب) وهي سكن الموظفين من العاملين بالخدمات المختلفة. ويتضح من تحليل البيانات استحواذ اليوسفية على المرتبة الأولى لقاطنى نمط المسكن المستقل بانل

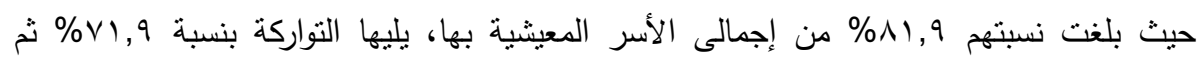
يعقوب المنصور بنسبة 79,0\% وهو ما يشير إلى تركز النمط وارتباطه بالمقاطعات القديمة وهي لإني

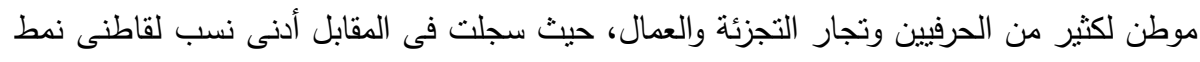

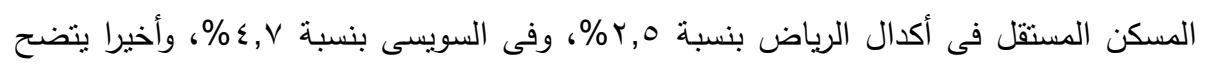

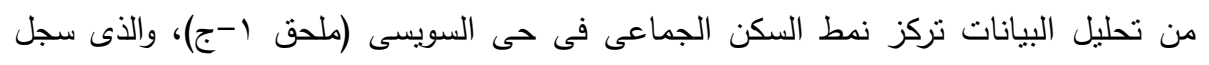

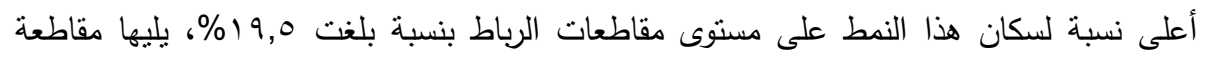

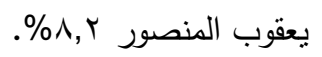

\section{r}

تتكل الأسرة الوحدة الصغيرة فى قاعدة التركيب الاجتماعي، وتحظى دراسته وإلقاء الضوء عليه بأهمية كبيرة لتأثيرها فى سمات المحلة العمرانية وتنتكيل خصائصها، بينما تعكس التباينات المكانية

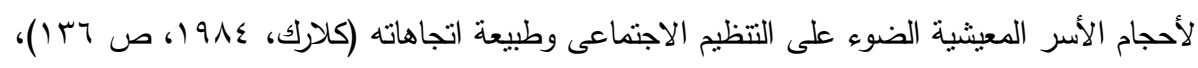

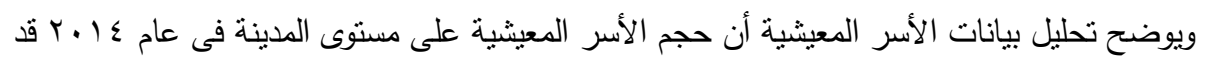

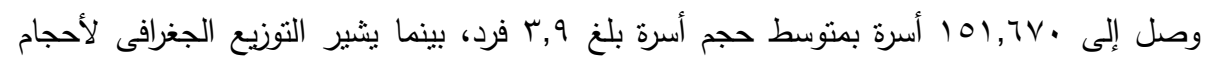

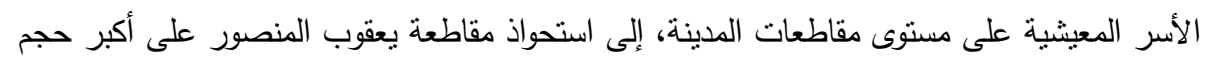

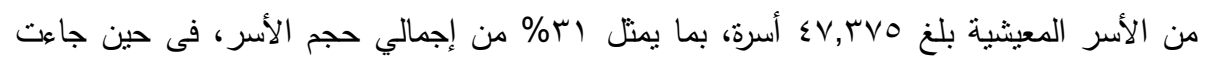

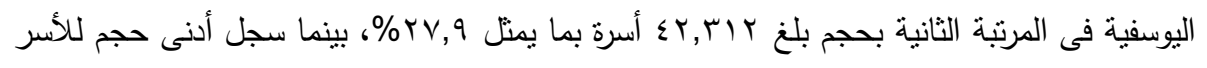

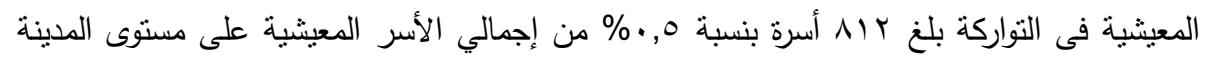

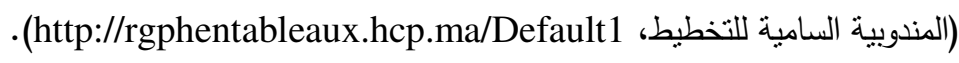

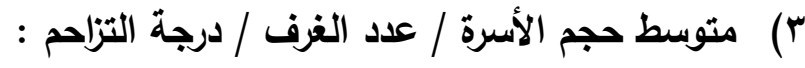

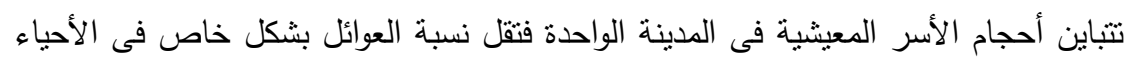
الراقية، بينما تسود الأسر الممتدة والعوائل بأحجامها الكبيرة فى الأحياء القديمة، وذللك لأن الأحياء

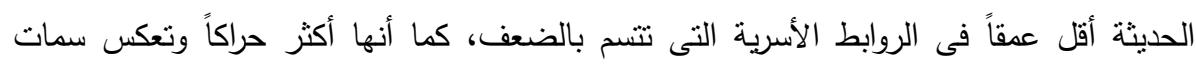


المجتمع المدنى (كلارك، £1911، ص ب ب 1)، وقد سجل متوسط حجم الأسرة على مستوى الرباط

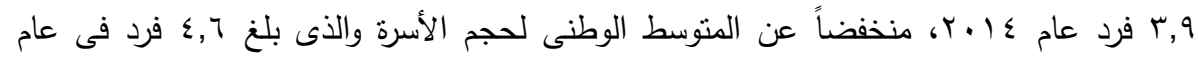

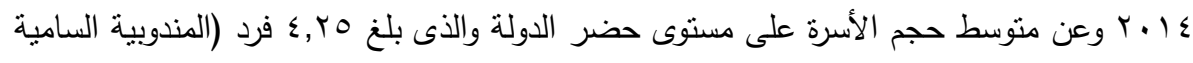

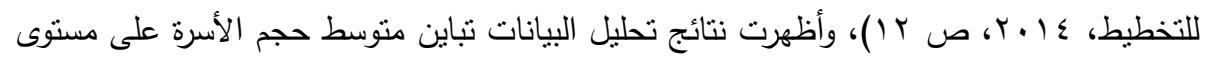
المقاطعات، حيث سجلت مقاطعة التواركة أعلى متوسط لحجم الأسرة فاق المتوسط العام للمدينة

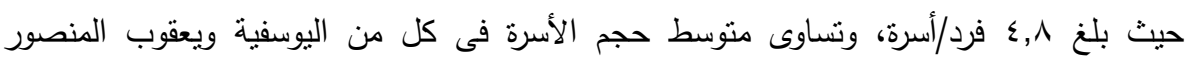

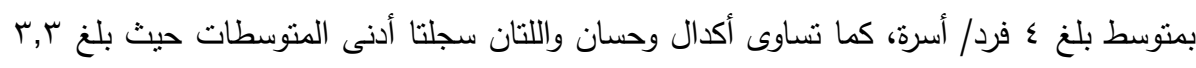

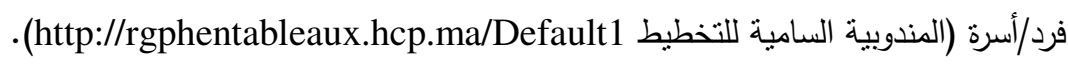

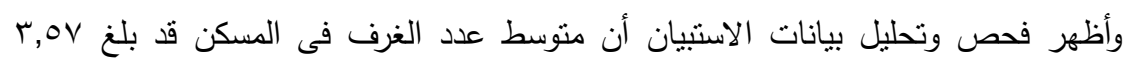

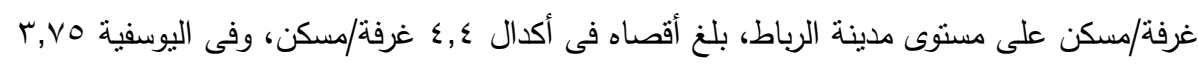

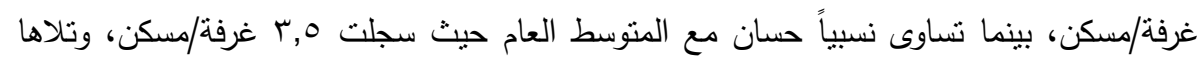

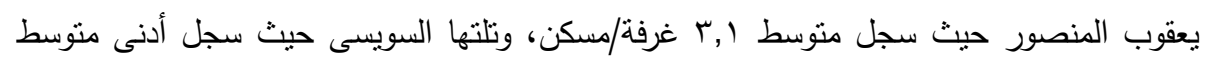
لعدد الغرف فى المسكن بلغ ب غرفة/مسكن.

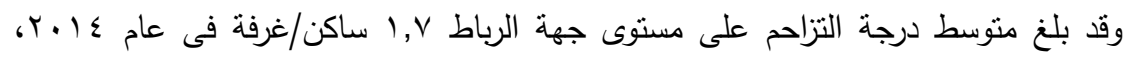

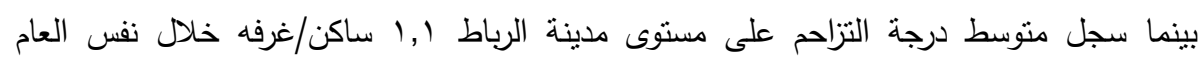

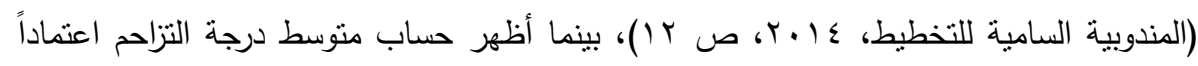

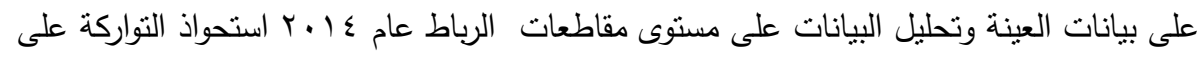

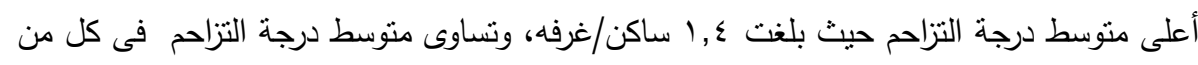

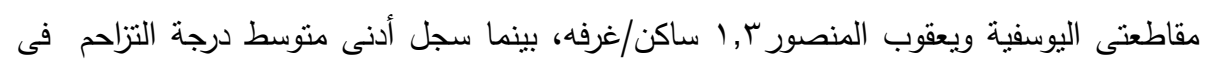

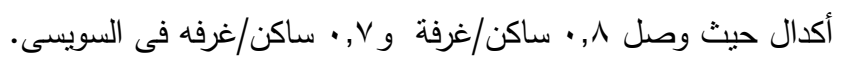

\section{ع) ع عدد الطوابق وإستخدام الدور الأرضى :}

أوضحت الملاحظة الميدانية وفحص بيانات الانتبيان وتحليلها أن متوسط عدد طوابق المسكن

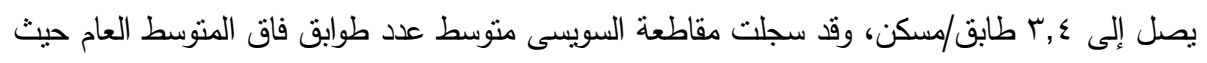

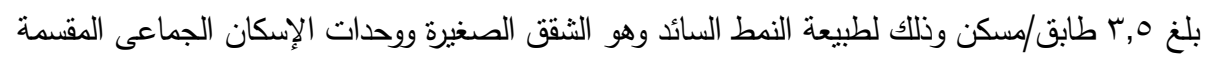

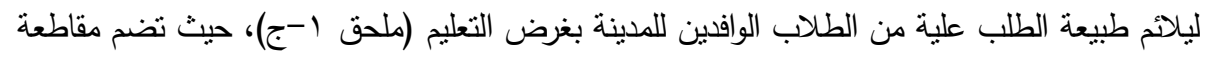

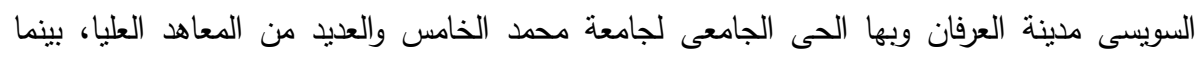

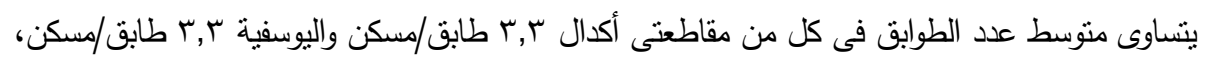

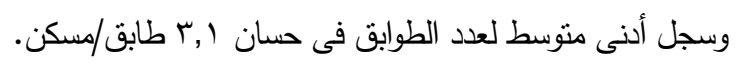


اتضح أيضاً طبقاً للملاحظة الميدانية وتحليل بيانات الاستبيان سيادة الاستخدام السكنى

وغلبته على استخدام الطابق الأرضى بنسبة Y, 10\% من إجمالي العينة، بينما بلغت نسبة الاستخدام

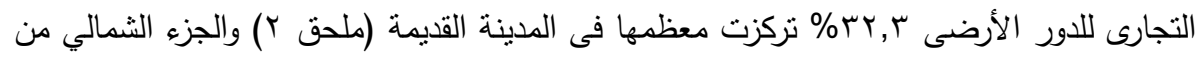

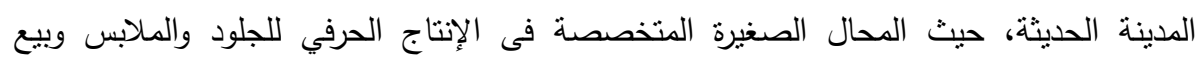

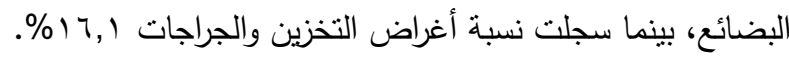

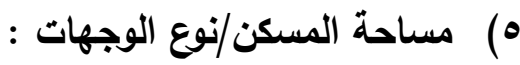

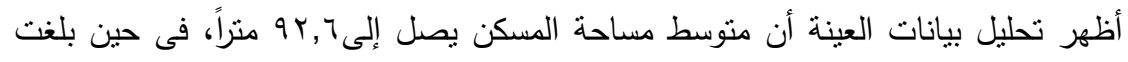

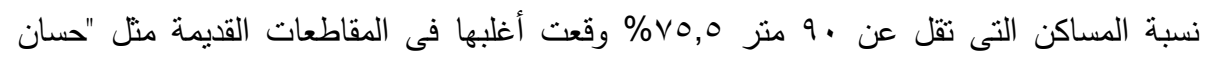
واليوسفية" والقطاعات القديمة من محيطها، فقد بلغ منوسط مساحة المسكن بها فى يعقوب وحسان

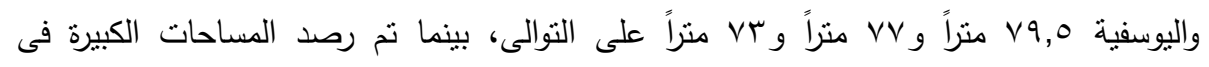

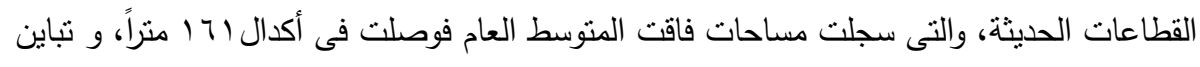

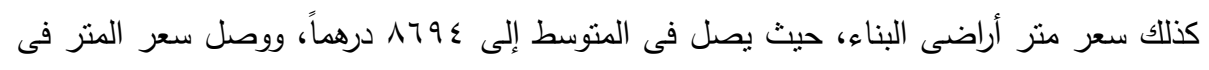

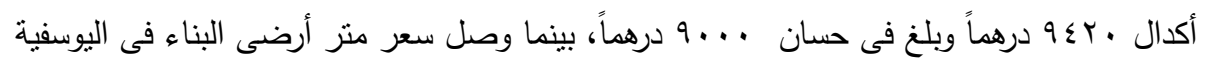

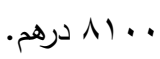

وقد تتوعت طبيعة وجهات المسكن فى المدينة بين الصباغة "محارة "والجرانيت و الرخام، وتباينت

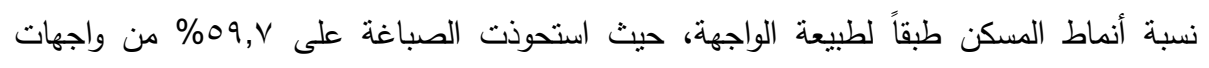

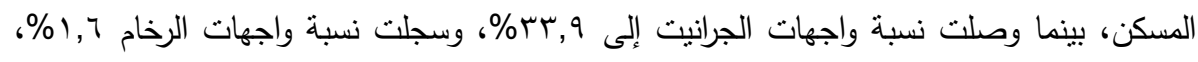

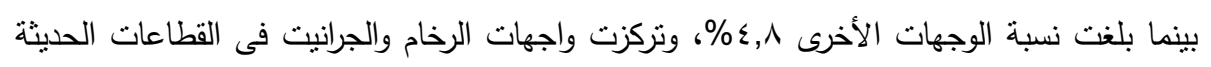

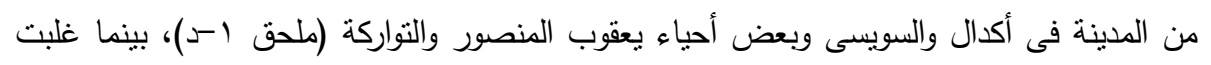

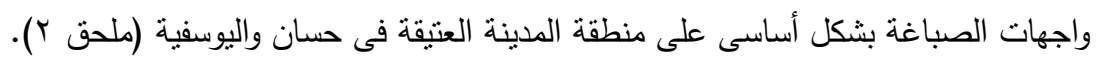

\section{7) نمط الإثغال (طبيعة الحيازة والملكية) :}

تعددت طبيعة حالات الإشغال طبقاً لما أوضحته البيانات الرسمية لتعداد الرسمى للسكان فى

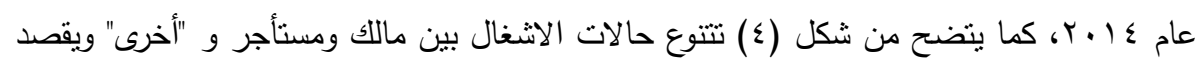
بها الاسكان الجماعي للطلاب والقاطنين مع ذويهم ويشير تحليل البيانات إلى ارتفاع نسبة الإشغال

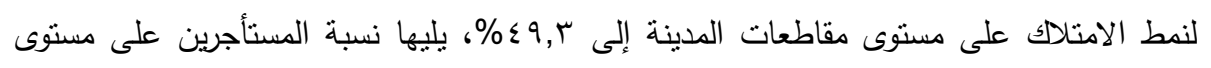

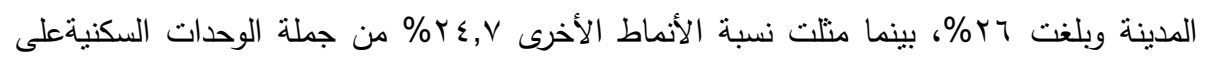

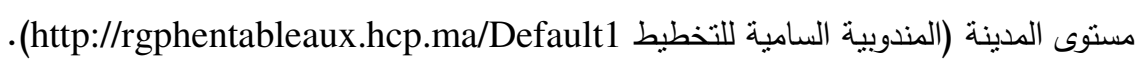




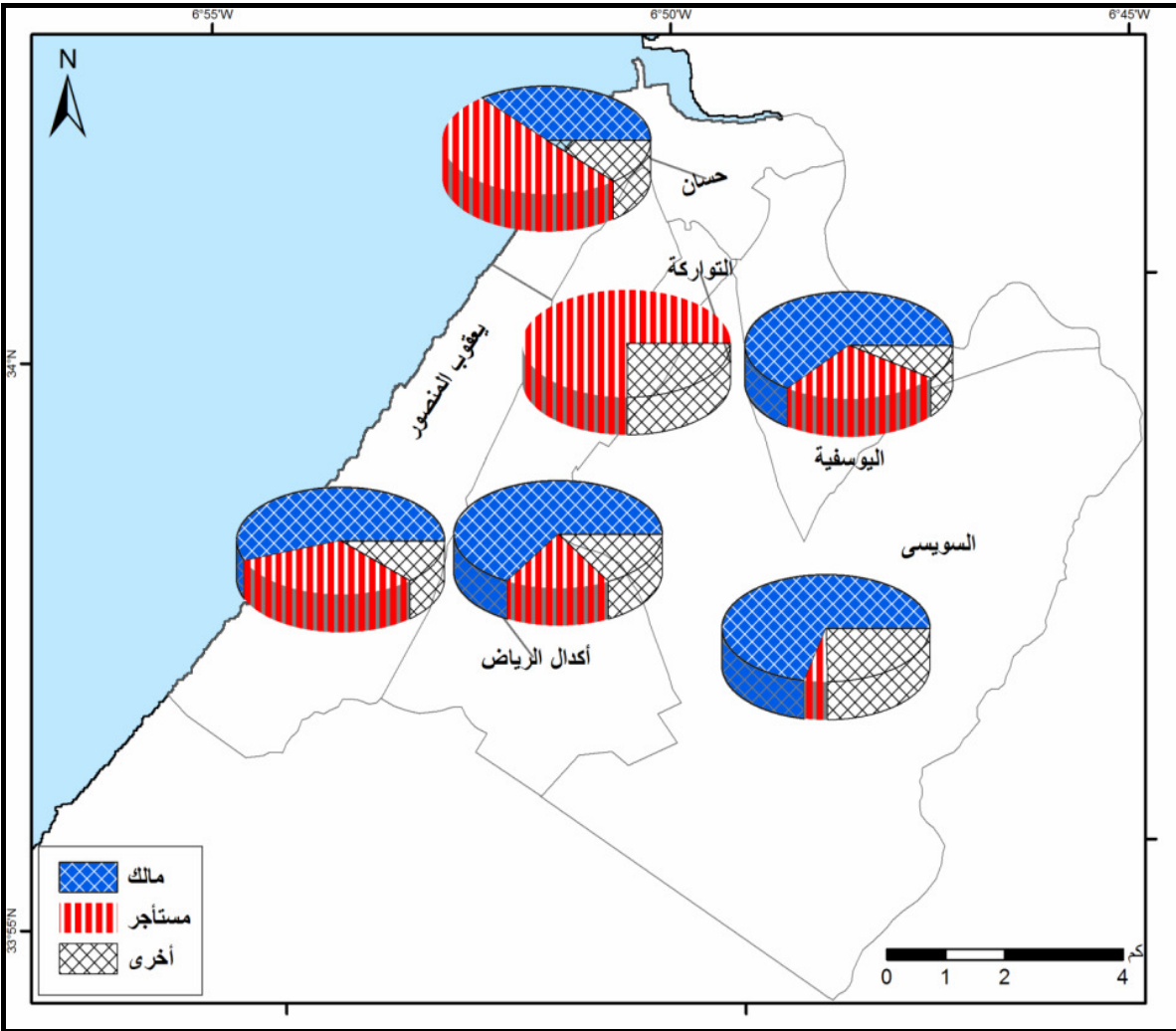

شكل (؟) : توزيع الأسر المعيشية طبقاً لحيازة المسكن على مستوى مقاطعات الرباط عام ؟ ا ـ. أ.

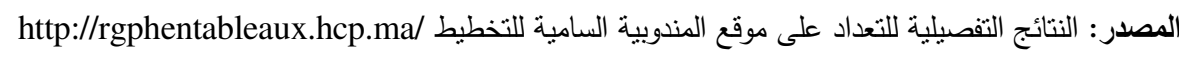

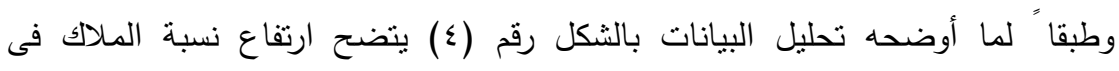

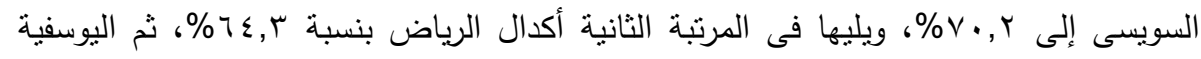

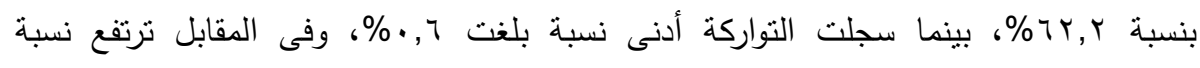

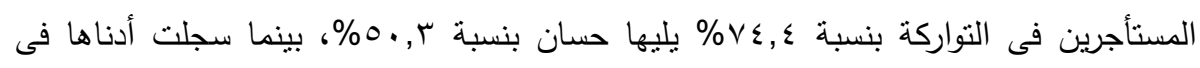
السويسى بنسبة 10,\%، ويتضح من تحليل البيانات نساوى نسب الأنماط الأخرى لحالة الإشغال

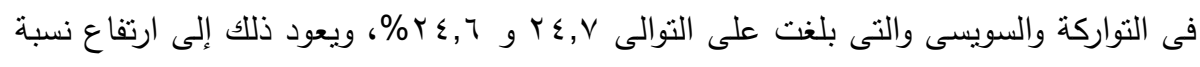

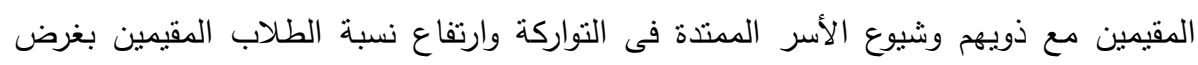
التعليم فى السويسى كما اتضح من الدراسة الميدانية. 


\section{(V تجهيزات وتسهيلات المسكن والإمداد بخدمات البنية الأساسية :}

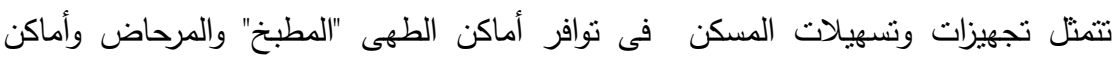

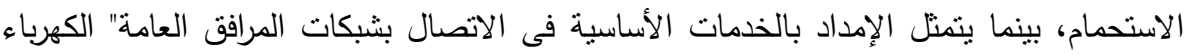

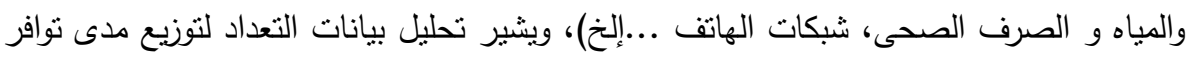

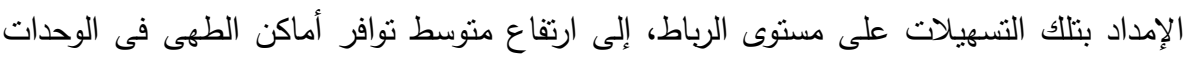

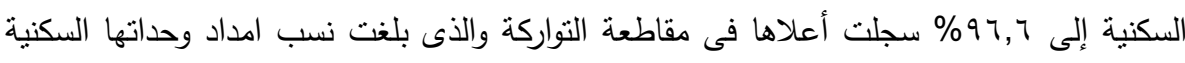

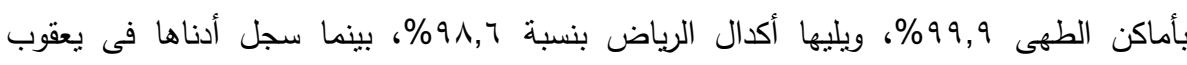

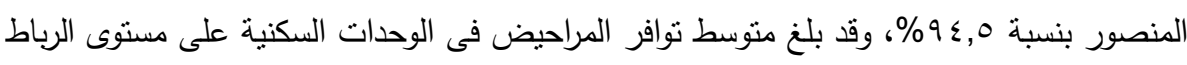

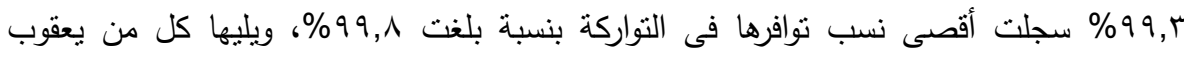

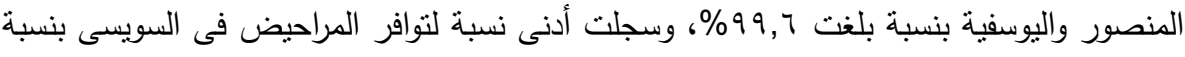

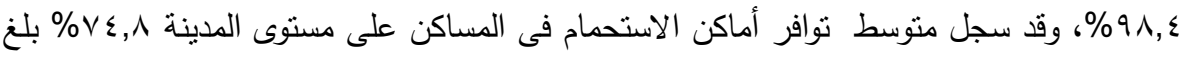

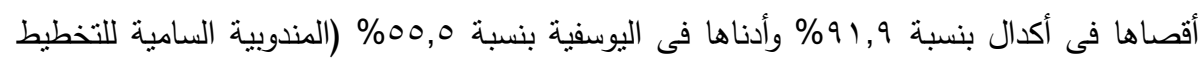
.(http://rgphentableaux.hcp.ma/Default1

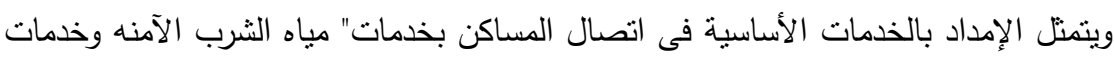

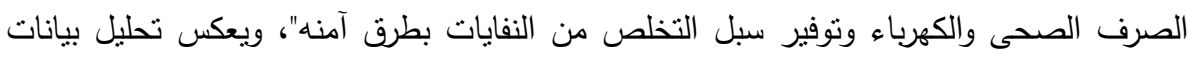

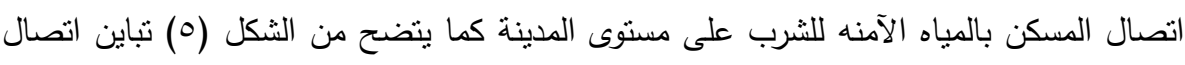

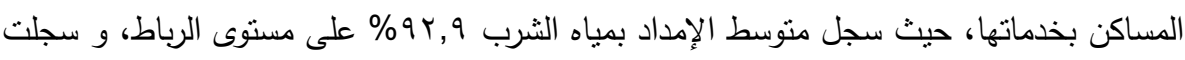

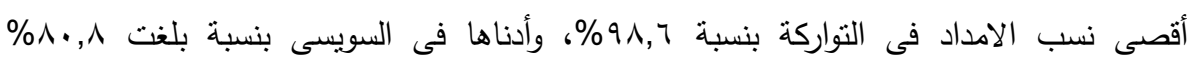

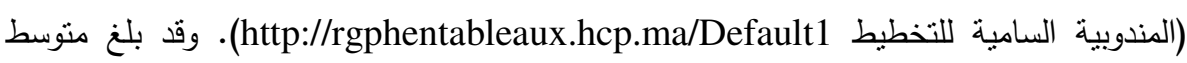

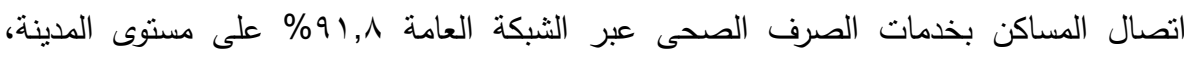

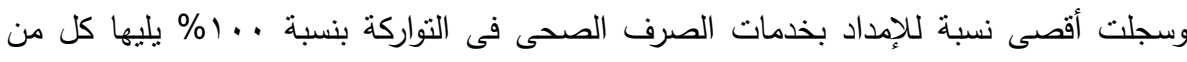

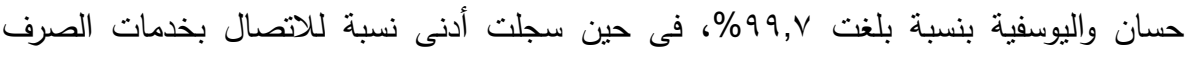

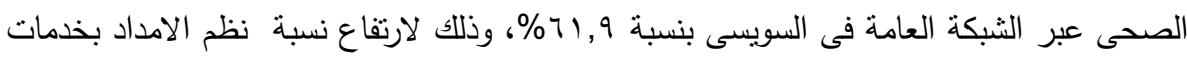

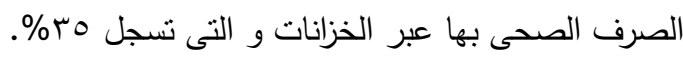

وقد سجل منوسط نسب اتصال المسكن وامداده بالكهرباء على مستوى الرباط 90,7\%

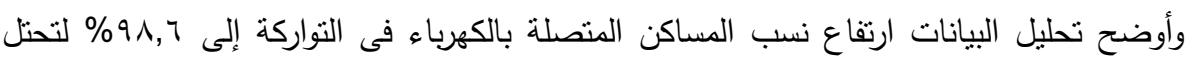

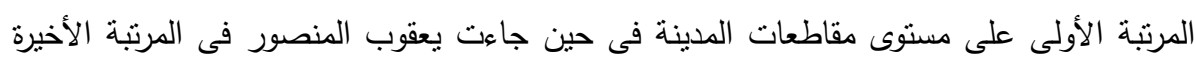

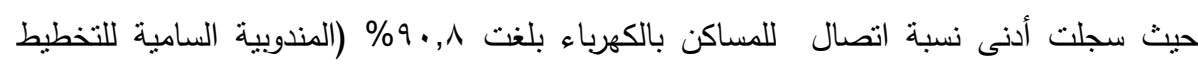
.(http://rgphentableaux.hcp.ma/Default1 


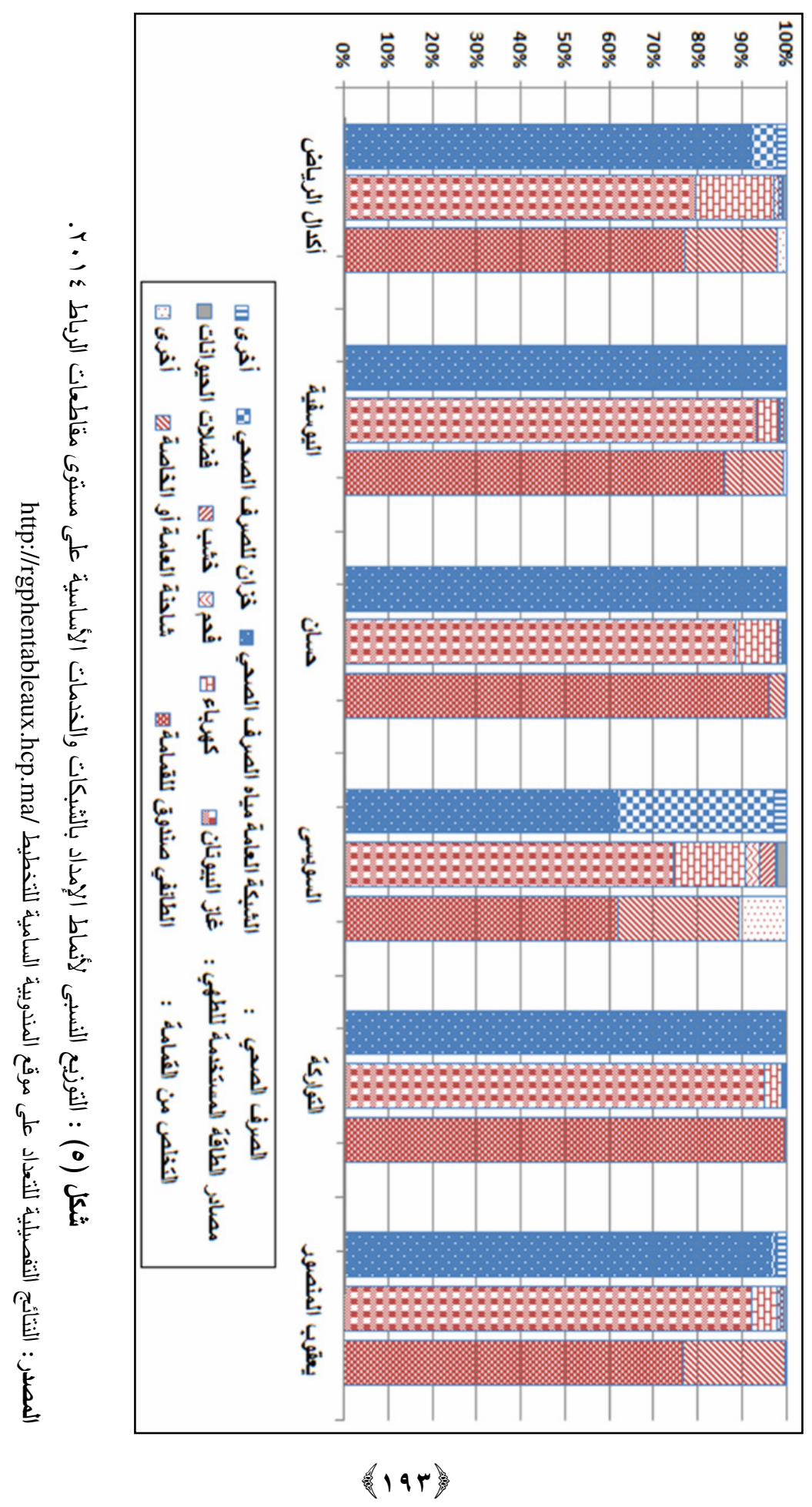


وتتتوع نظم التخلص الآمن من النفايات بين جامعى القمامة التابعين للشركات الرسمية حكومية

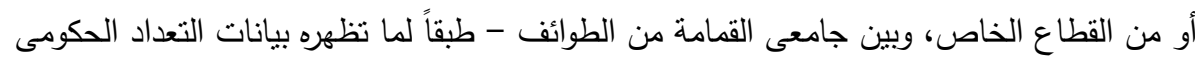
فى عام \& 1. 1، وقد وصل منوسط الإمداد بخدمات التخلص من النفايات على مستوى المدينة

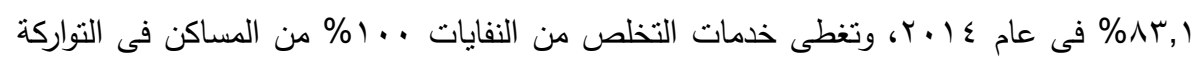

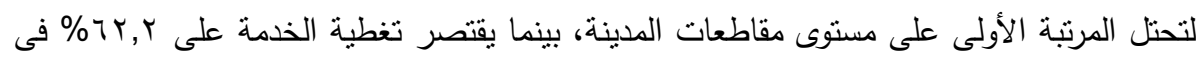

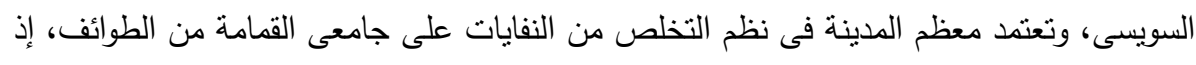

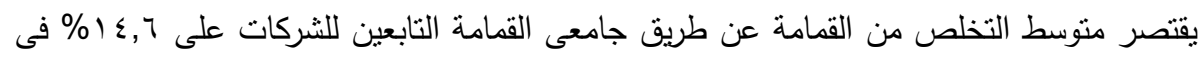

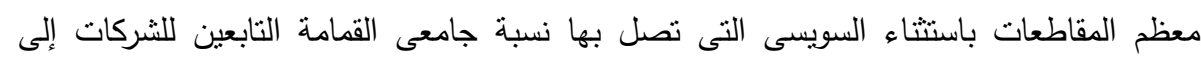

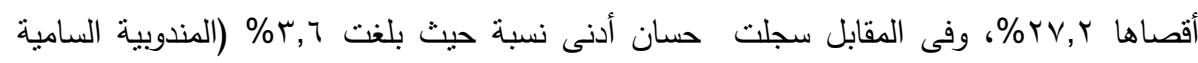

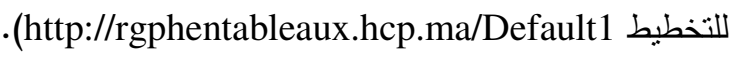

كما توافرت نظم الإمداد المساكن بالطاقة المستخدمة فى الطهى، ونتوعت بين (غاز البيوتان

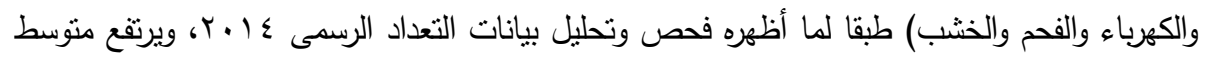

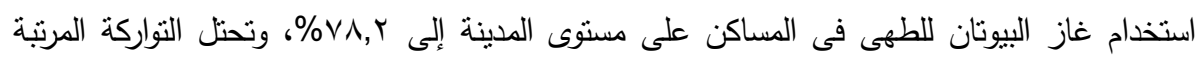

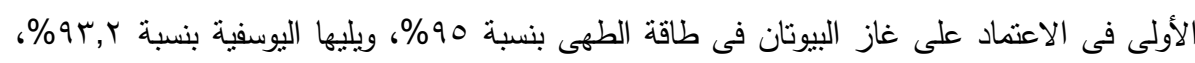

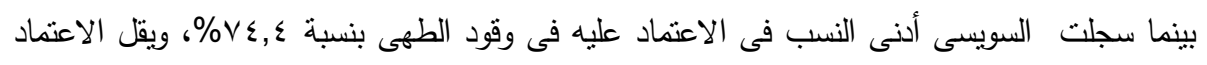
على الكهرباء فى الرباط كوقود للطهى حيث سجل منوسط استخدامها كوقود للطهى على مانى مستوى المدينة

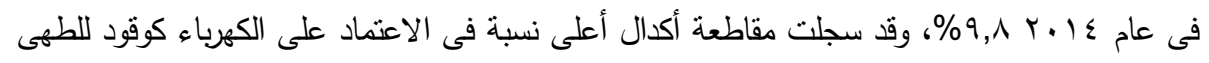

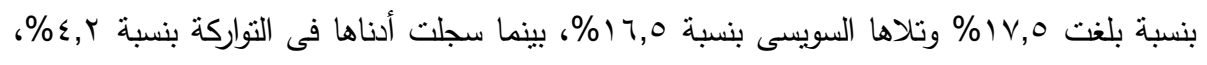

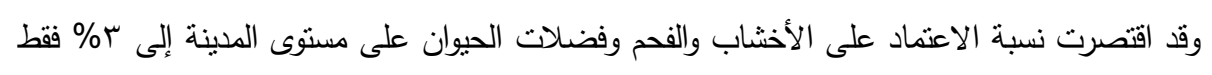

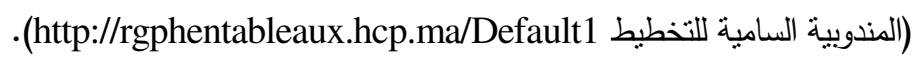

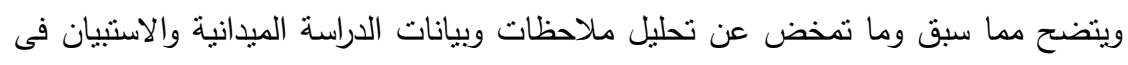

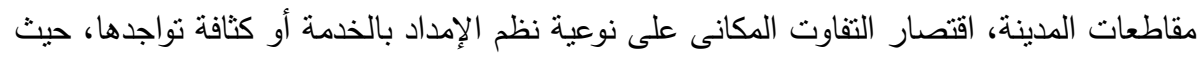

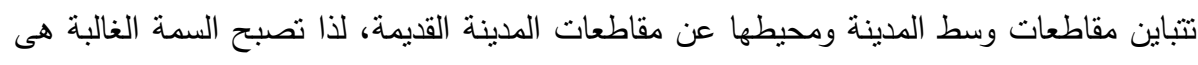

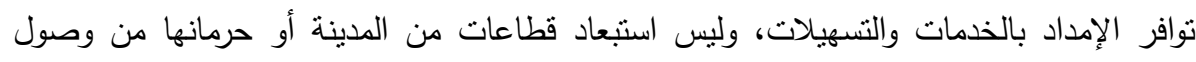

$$
\text { الخدمة كما فى أغلب مدن العالم النامى. }
$$

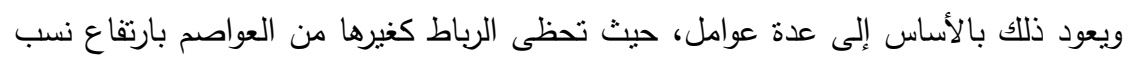

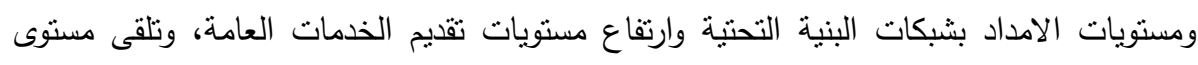

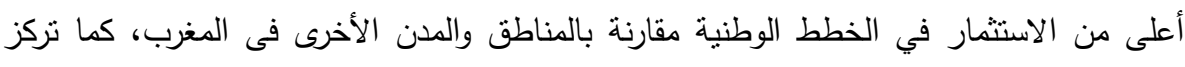
قطاعات الاستثمار الحكومى بشدة على تطوير الأشغال العامة والتعليم والصحة في المدينة (الوكالة الصالة

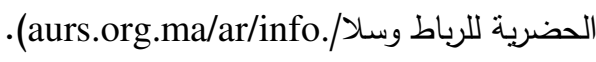


spatial بينما عكست طبيعة تباين توزيع أنماط المسكن سيادة فكرة التجزئة الاجتماعية المكانية fragmentation

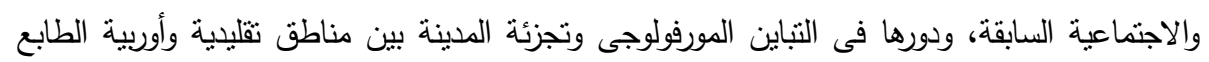

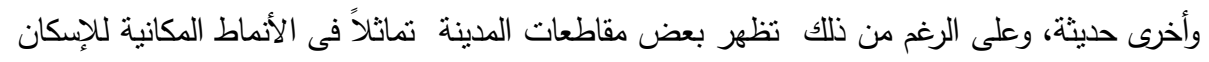

بشكل عام طبقاً لقانونية المسكن، وطبيعة ونوعية الخدمات والنسهيلات وسهولة الوصول إليها.

\section{ثانياً - خصائص التركيب السكانى لمدينة الرباط :}

تنثمل دراسة العناصر السكانية عناصر عديدة منها حجم السكان ونموهم ومكونات ذلك النمو

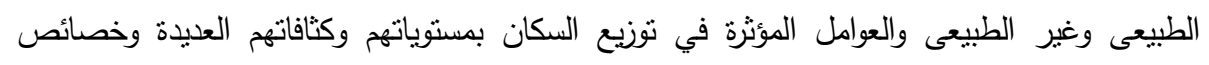

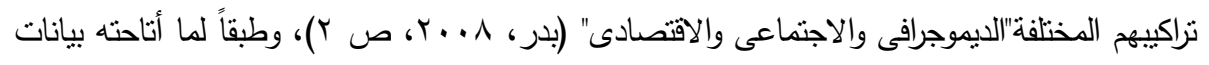

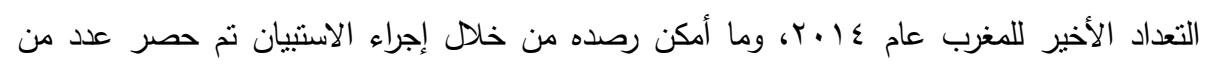

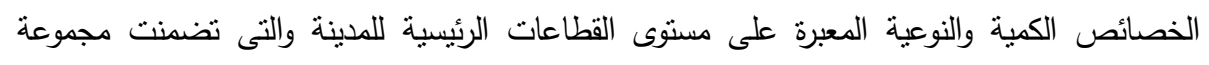

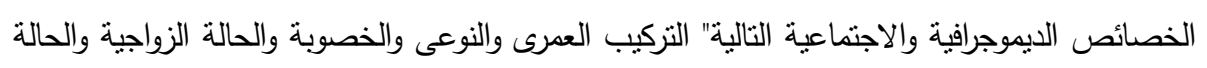
التعليمية)، بينما نضمنت الخصائص الاقتصادية (حالة العمل والحالة المهنية والدخل الثهرىى).

\section{( ) (الخصائص الديموجرافية :}

تتميز الخصائص والملامح الديموجرافية لمجتمع ما بالتغير والتباين على مستوى الحيز الجغرافى،

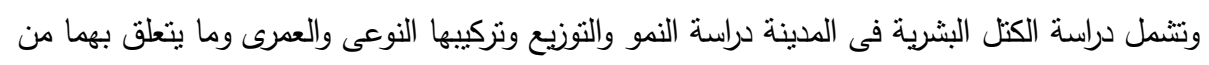

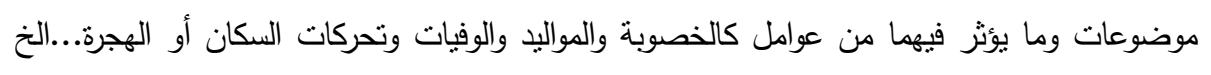

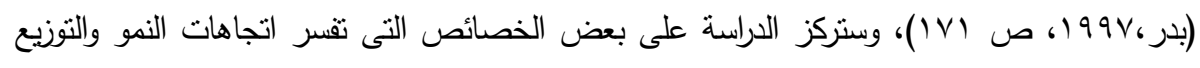

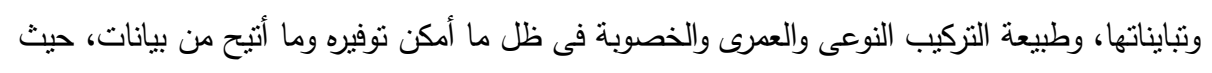

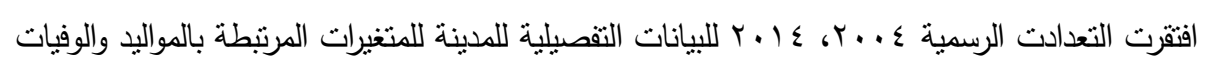
والزيادة الطبيعية والهجرة التى أنيحت بياناتها حتى مسنوى الجهات.

$$
\text { أ- اتجاهات نمو السكان : }
$$

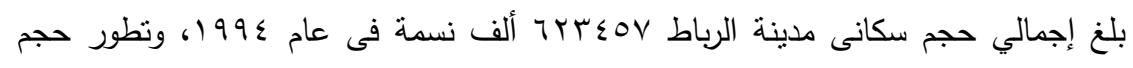

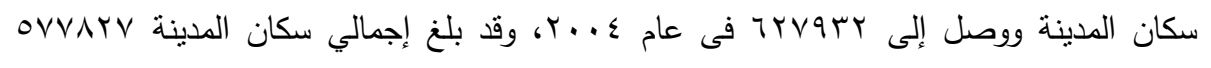

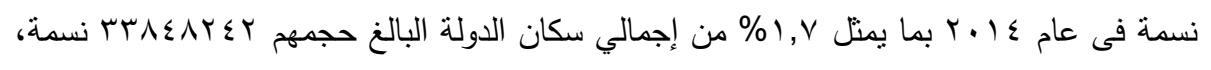

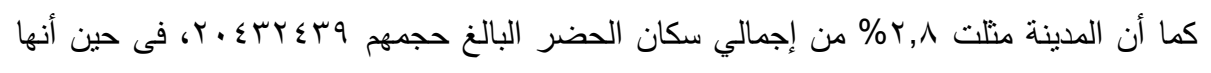




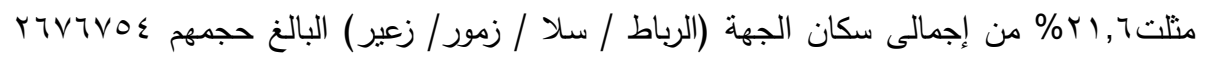

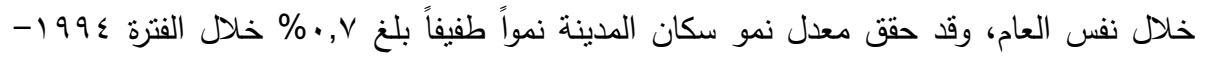

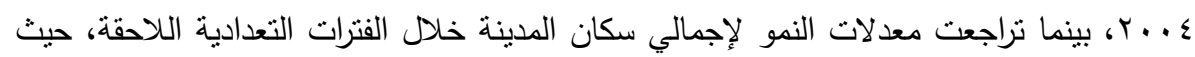

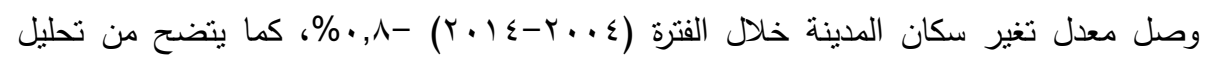

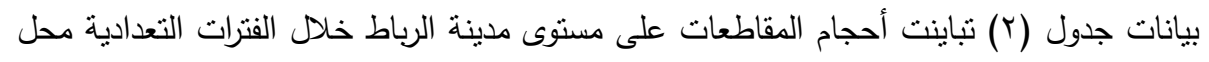
الدراسة، حيث استحوذت مقاطعة يعقوب المنصور على أعلى حجم من سكان المدينة خلاد الفترات

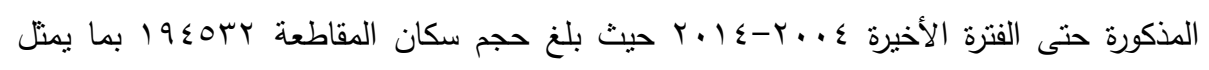

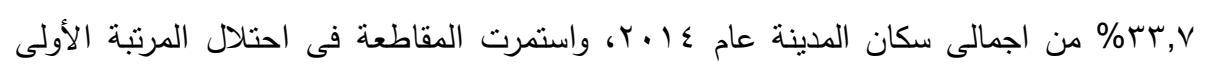

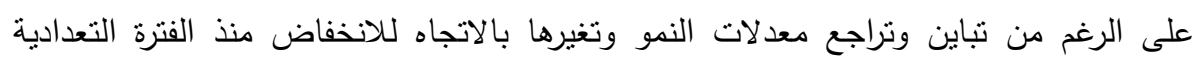

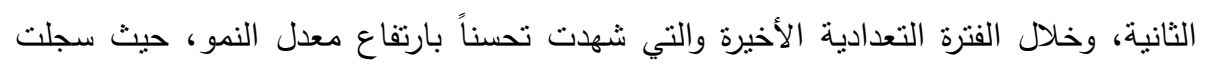

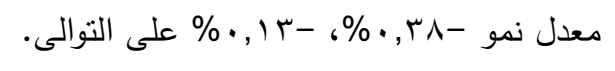

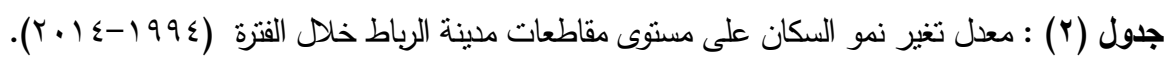

\begin{tabular}{|c|c|c|c|c|c|c|}
\hline 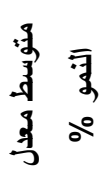 & $\begin{array}{ll}3 & \vdots \\
3 & \vdots \\
3 & 1 \\
3 & \vdots \\
\circ & 2\end{array}$ & 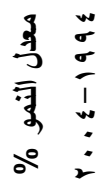 & $\frac{*}{1}=$ & $\frac{{ }^{*}}{\mathfrak{y}}:$ & 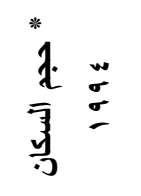 & المقاطعة \\
\hline$\cdot, Y Y$ & $1, \leqslant \vee-$ & $r, Y \leq$ & VVYOV & 9.071 & $v \leqslant \ldots$ & أكدال الرياض \\
\hline$\cdot, \cdot 1$ & $\cdot, 1 r-$ & $\cdot, 17$ & 18.071 & IVYATT & IV.ITی & اليوسفية \\
\hline $1, r)-$ & $1,01-$ & $1, Y r-$ & $1.11 \times 9$ & IYAEYO & $1 \leq 7 \leq \wedge \wedge$ & حسان \\
\hline$\cdot, \Gamma \leq-$ & $1, \leqslant 0-$ & $\cdot, 9$ & צדצמדז & TVTTL & ro.v. & السويسى \\
\hline$r, O V-$ & $r, q 1-$ & $r, \cdot 1-$ & rqT & $T \leqslant O Y$ & $\wedge \cdot \wedge$. & التواركة \\
\hline., $11-$ & $\cdot, \Gamma \wedge-$ & $\cdot, 1 \Gamma$ & $19 \leqslant 0 r r$ & $r \cdot r r \cdot 1$ & $1997 \times 0$ & يعقوب المنصور \\
\hline$\cdot, r v-$ & $\cdot, \wedge-$ & $\cdot, \cdot V$ & OVVAYV & trvatr & Irr $\leqslant 0 V$ & جملة الرياط \\
\hline
\end{tabular}

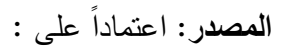

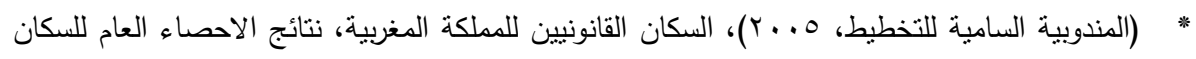

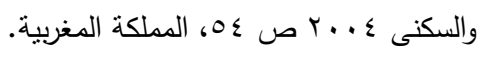

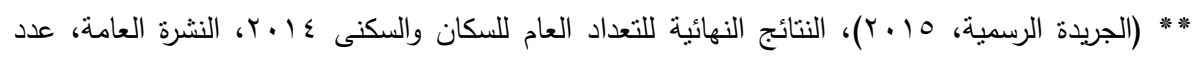

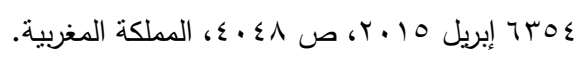




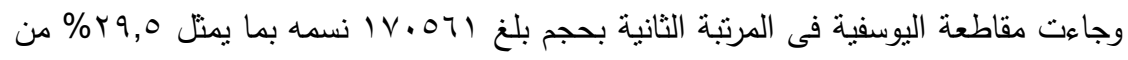

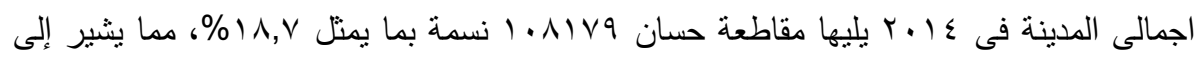

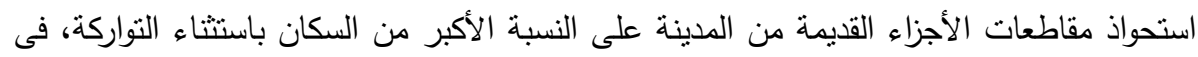
مقابل الأجزاء الأحدث فى أكدال الرياض والسويسى، بينما بشير تحليل معدلات النمو إلى أنه لم لم

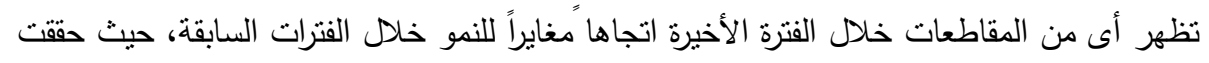

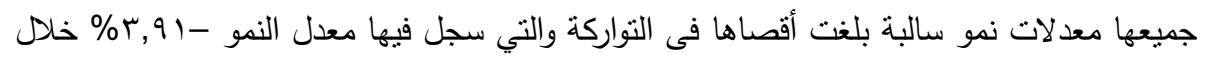

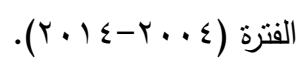

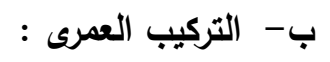

تعد دراسة التركيب العمرى مسألة هامة فى دراسة جغرافية الحضر ، فتعد دراسة التراكيب

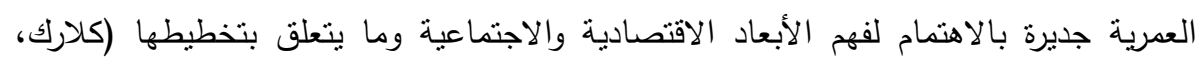

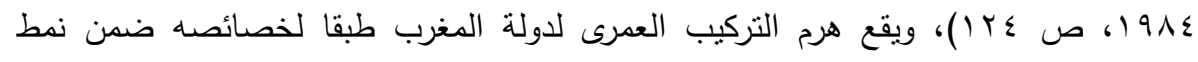
التركيب العمرى الفتى وفيه تمر الدول ببداية خطواتها نحو تحقيق التحول الديموجرافى هردي

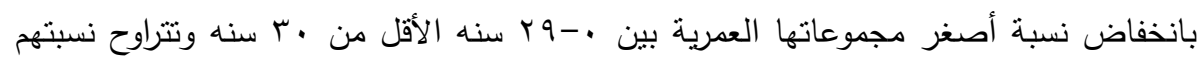

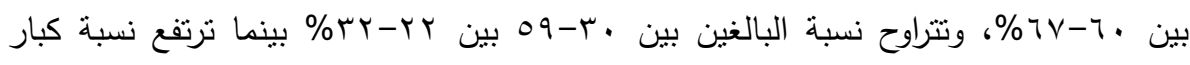

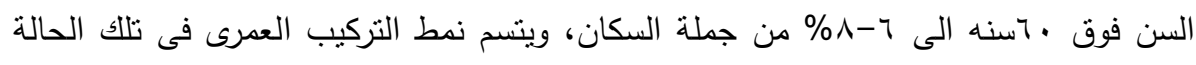

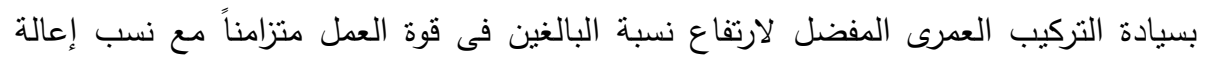

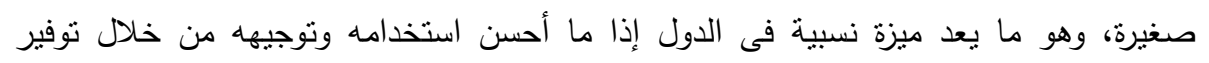

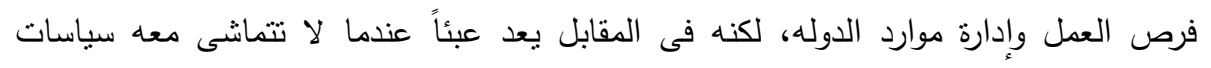

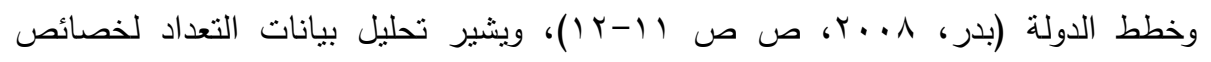

التركيب العمرى لسكان مدينة الرباط كما يتضح من الثكل رقم (؟).

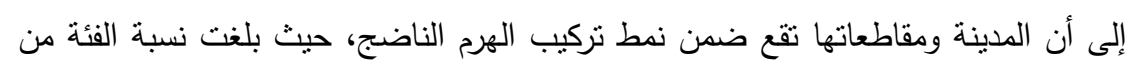

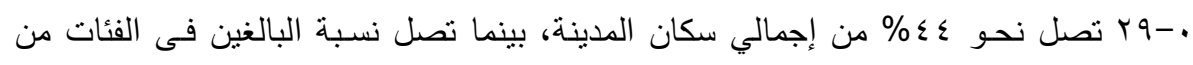

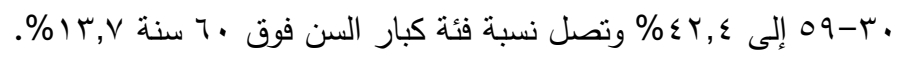

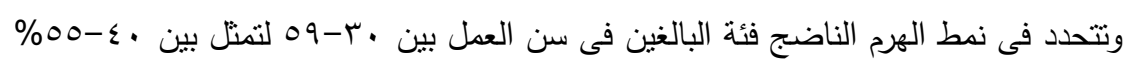

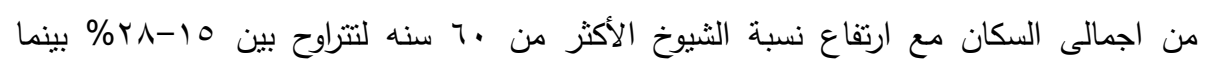

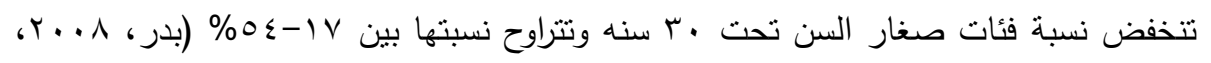
ص ص (1-r-1)، كما بشير التحليل التفيلى على مستوى المقاطعات إلى انطباق خصائص 


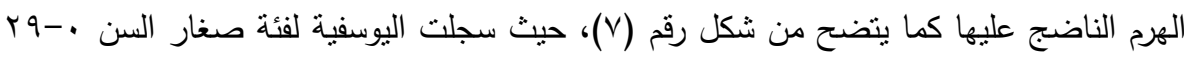

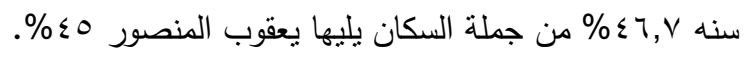

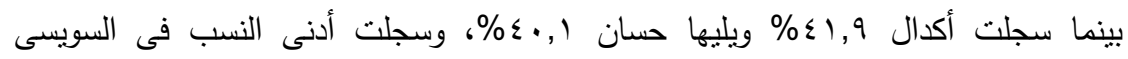

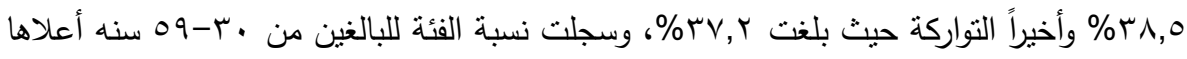

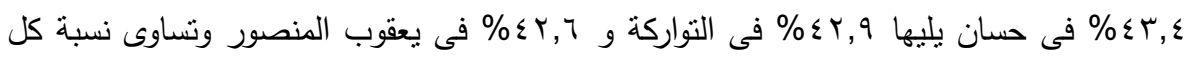

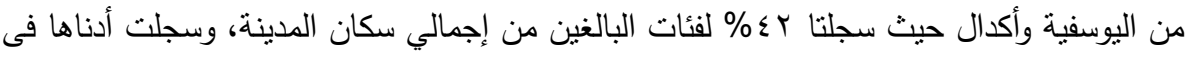

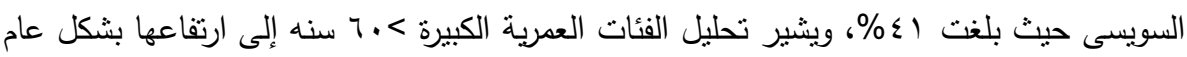

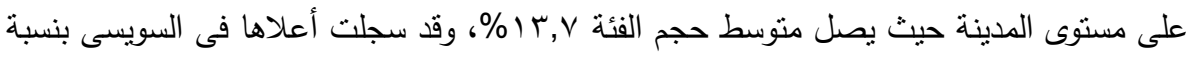

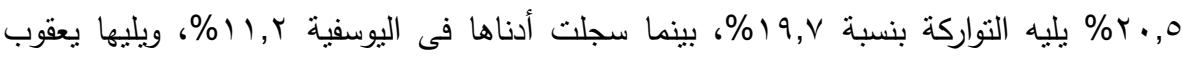

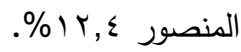

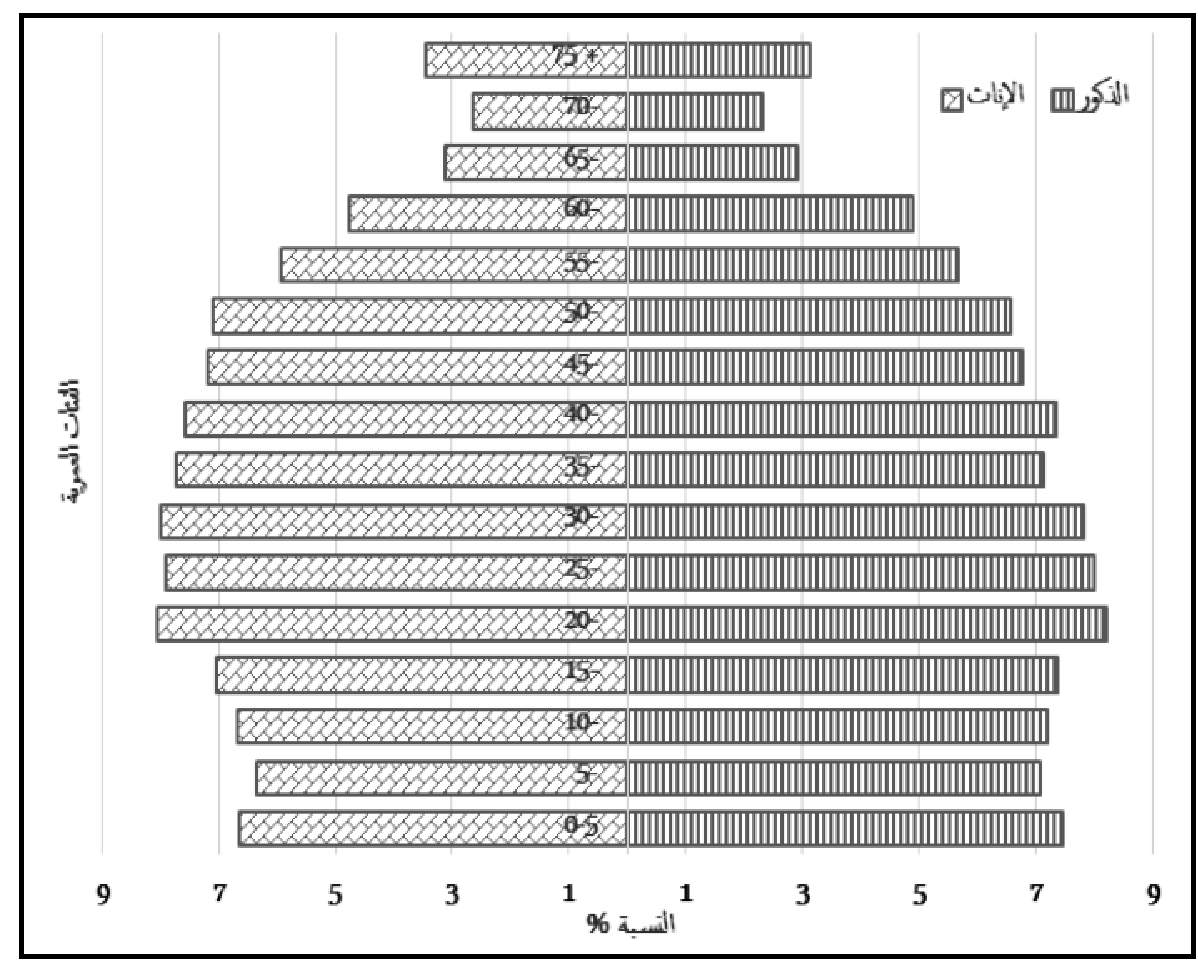

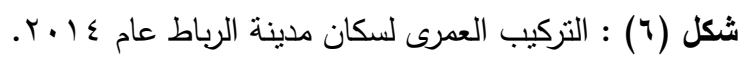

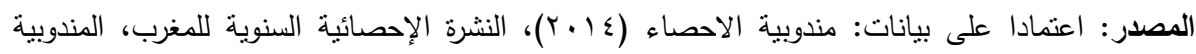
السامية للتخطيط، الرباط المغرب. 


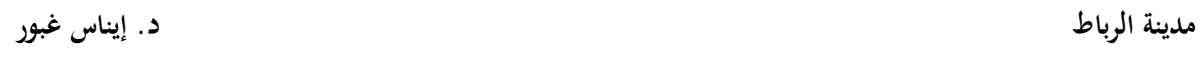

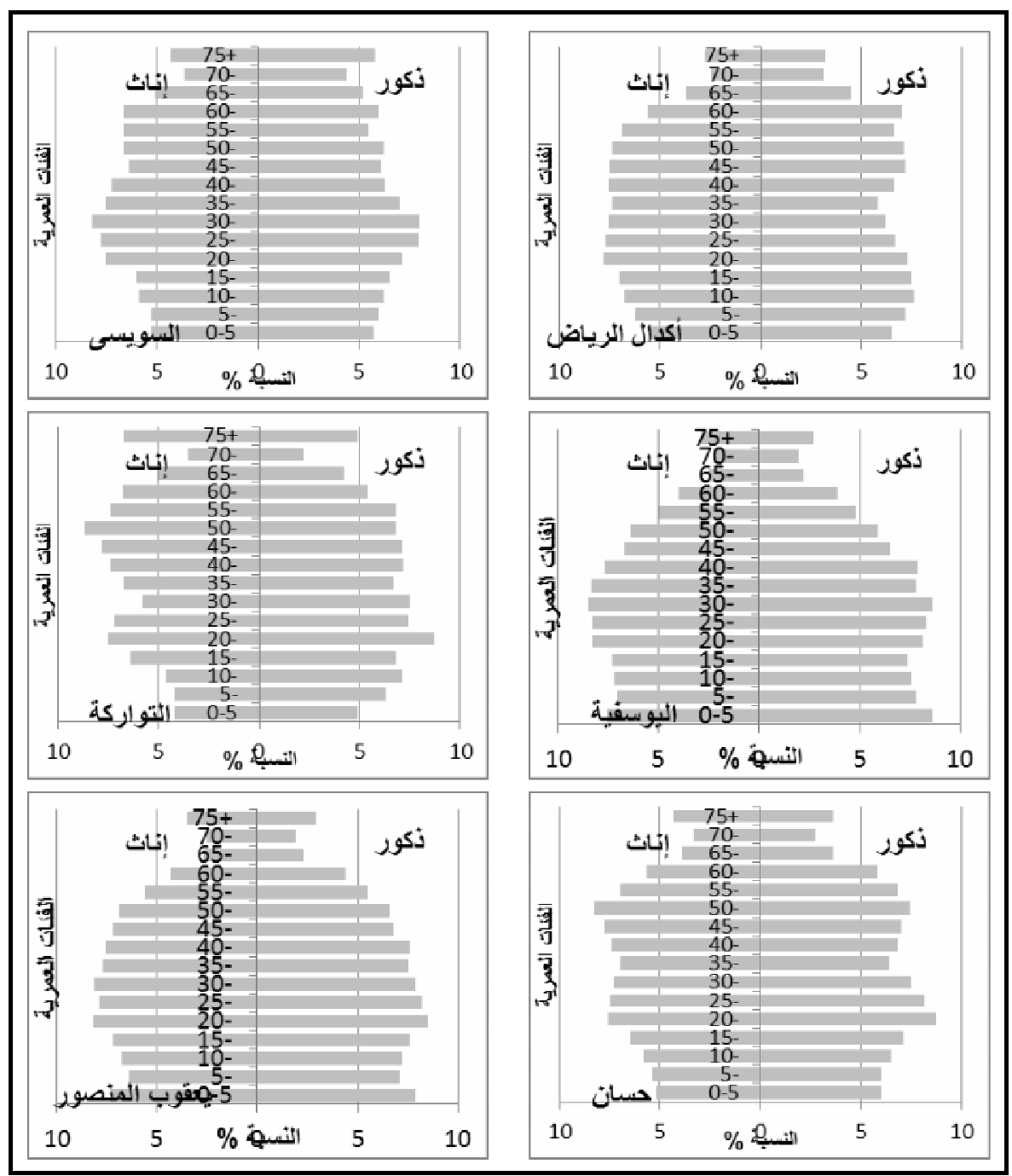

شكل (V) : التركيب العمرى للسكان على مستوى مقاطعات الرباط عام ؟ I. r.

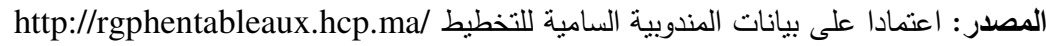

\section{ج- التركيب النوعى :}

تتطلب دراسة خصائص المراكز الحضرية دراسة التركيب النوعى للسكان كعنصر أساسى ضمن تركيب الهجتمع الحضرى، حيث يسمح التفاوت بين نسبة الإناث والذكور فى المراكز

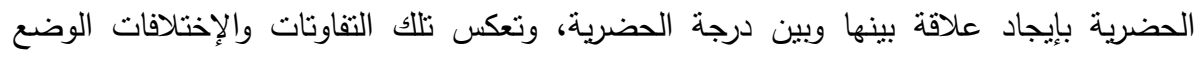

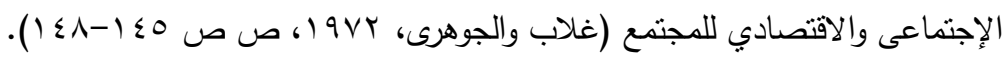

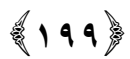


ويشير تحليل بيانات التركيب النوعى لسكان الرباط، كما يتضح من شكل رقم (^) إلى أن

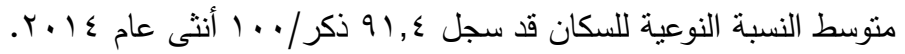

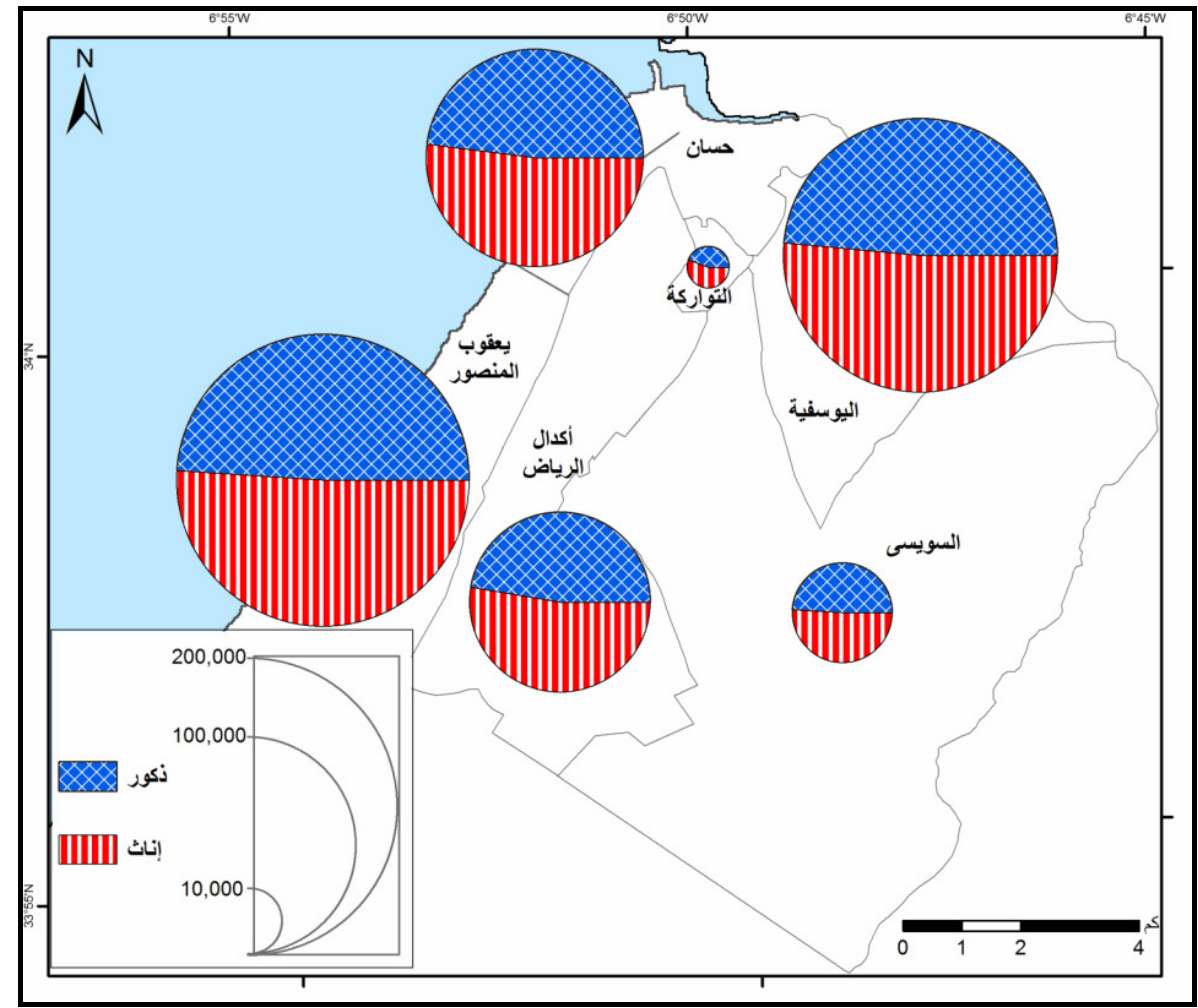

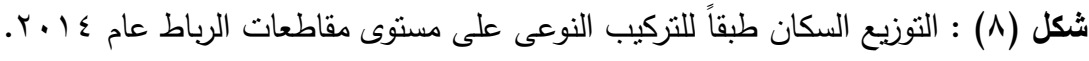

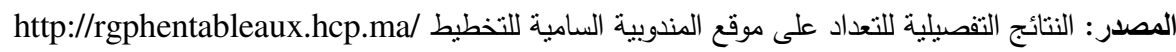

ويعكس تحليل البيانات تباين النسبة النوعية على مسنوى المقاطعات فى المدينة، حيث سجلت

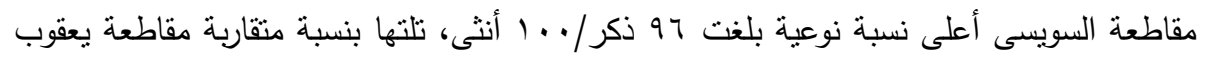

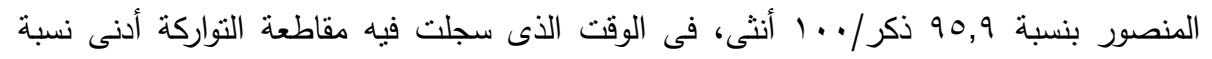

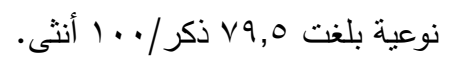
ويرجع نباين النسبة النوعية بشكل عام لنأثرها بثلاثة عوامل" نسبة مواليد الذكور والفرق فى الوفيات

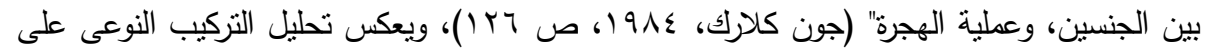

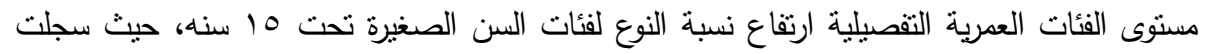

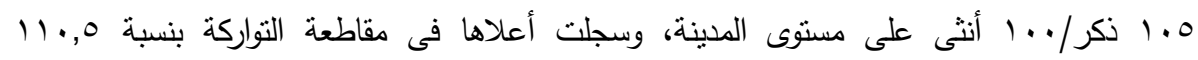

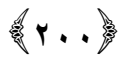




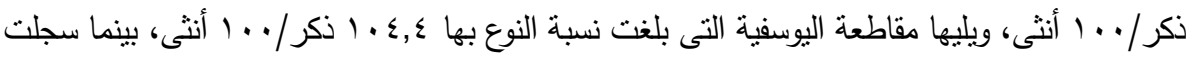

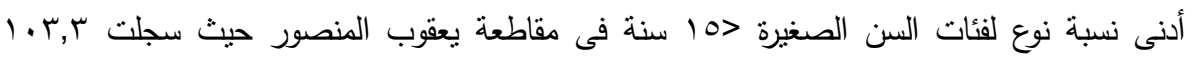

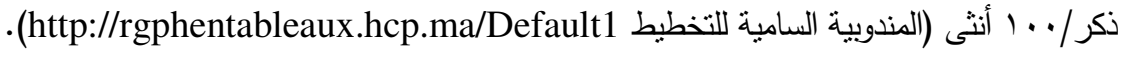

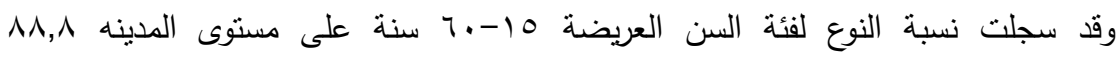

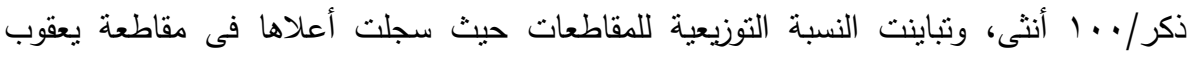

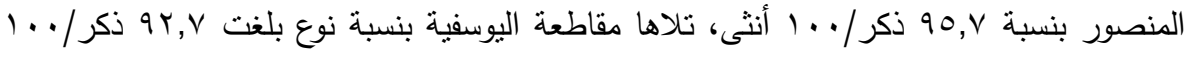

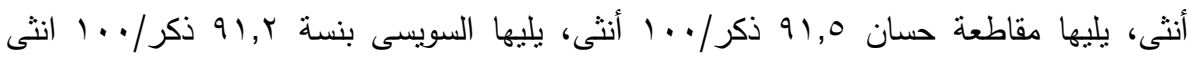

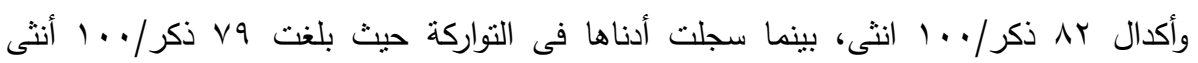

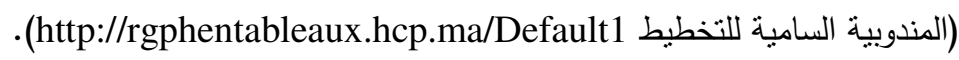
وقد أظهر تحليل فئات العمر النوعية العريضة تفاوتاً واضحاً، حيث ظهر استئنار المقاطعات

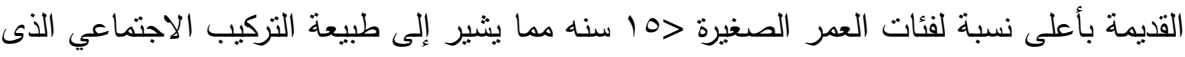

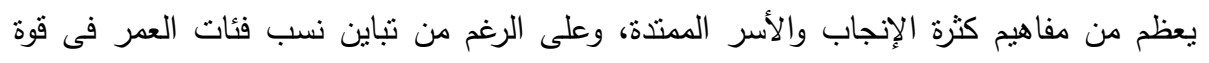

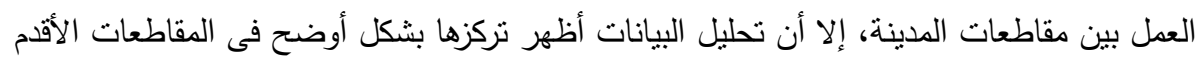

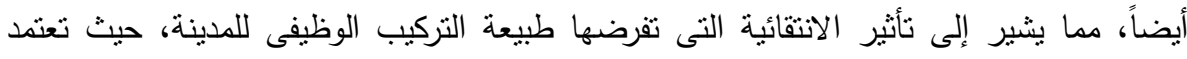
القطاعات الأقدم على الأعمال الحرفية واليدوية من الأنشطة التقليدية بعكس قطاعات الاته الإدارة

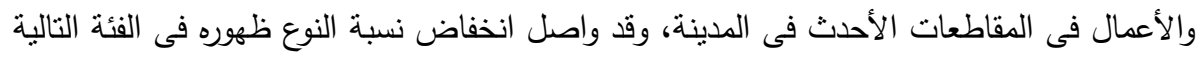

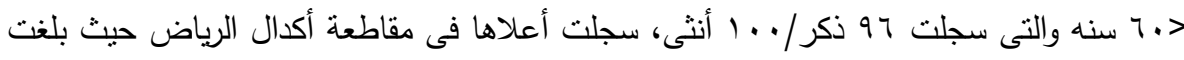

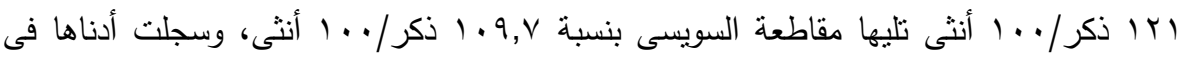

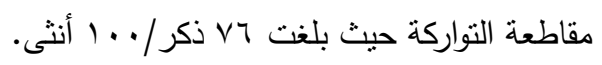

\section{د- الخصوية : - n}

تقف العديد من العوامل الديموجرافية والاقتصادية والاجتماعية خلف تتكيل طبيعة الخصوبة

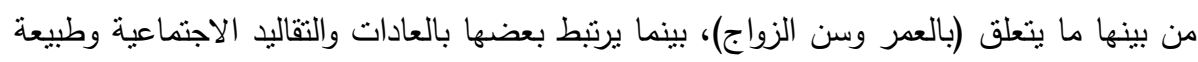

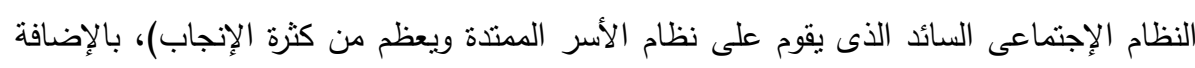

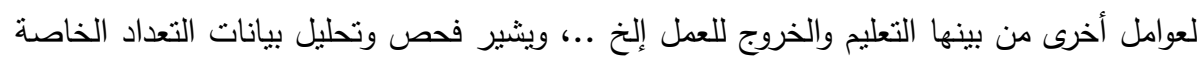

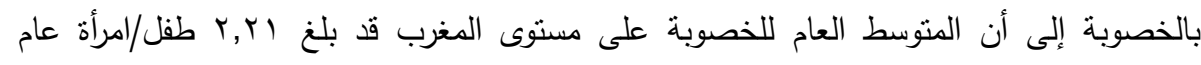

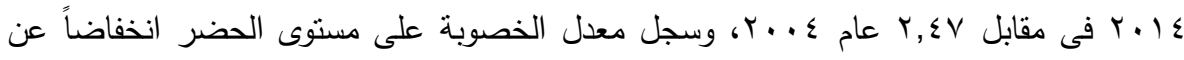

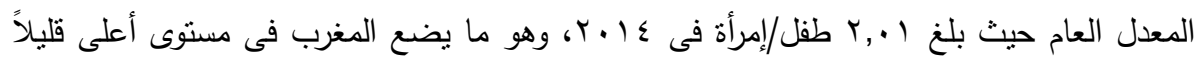

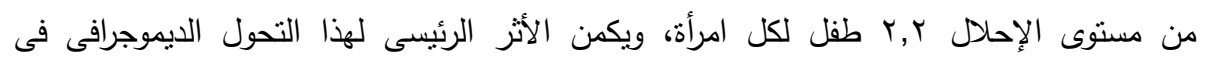




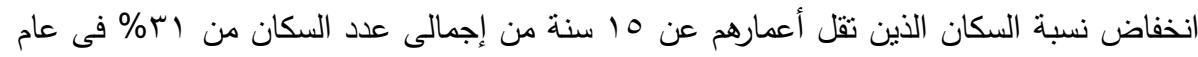

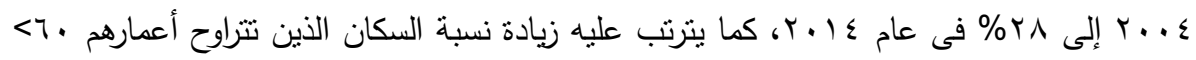

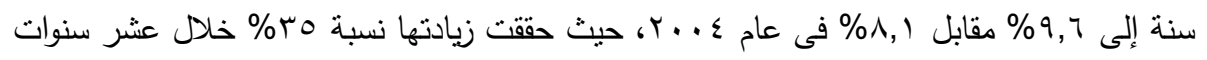

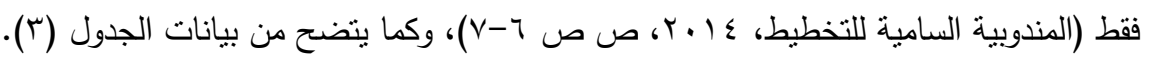

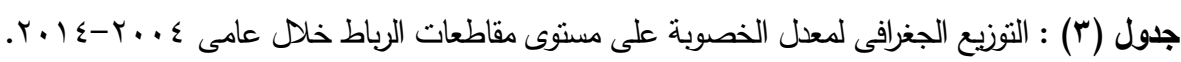

\begin{tabular}{|c|c|c|c|c|c|c|c|}
\hline جلرياط & المنصوب & التواركة & السويسى & حسان & اليوسفية & أرياض & المنطقة \\
\hline 1,7 & $1, v$ & 1 & $1, r$ & $1, \varepsilon$ & 1,1 & 1,0 & $r \ldots \varepsilon$ \\
\hline 1,7 & $1, \Lambda$ & $1, r$ & 1 & $1, \varepsilon$ & $1, V$ & 1,0 & $r \cdot 1 \leq$ \\
\hline
\end{tabular}

http://rgphentableaux.hcp.ma/ المصدر: الننائج التفصيلية للتعداد على موقع المندوبية السامية للتخطيط

تتخفض معدلات الخصوبة فى الرباط عن المتوسط القومى للاولة حيث سجل المتوسط العام

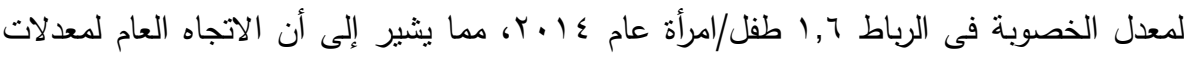

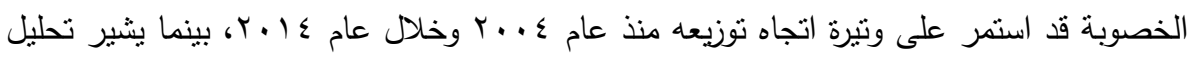

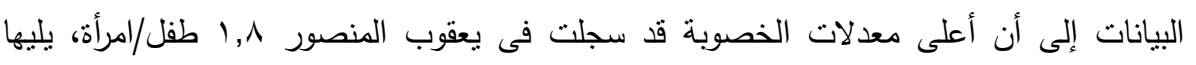

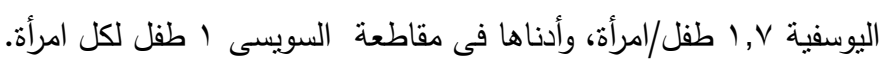

\section{r}

يعكس تحليل التركيب الاجتماعى للسكان العديد من ملامح المستوى الاجتماعى، وانعكاساته

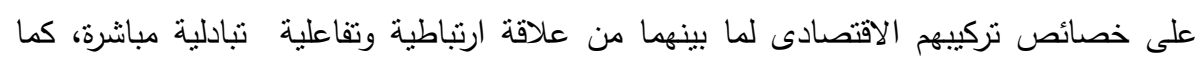

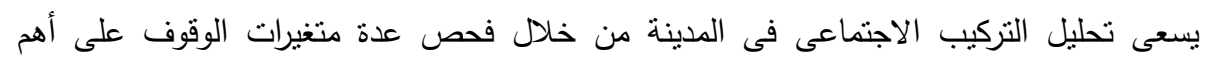

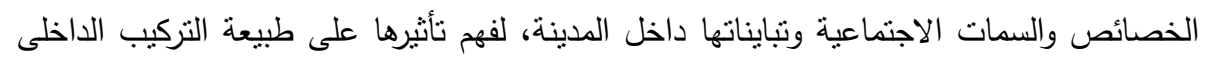

الاجتماعى للمقاطعات وتمايزها.

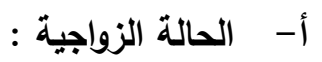

يؤثر كل من التركيب العمرى ونسبة النوع بشكل مباشر فى طبيعة الحالة الزواجية، كما تتأثر

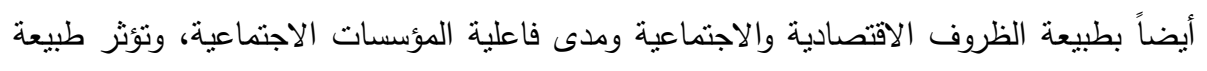

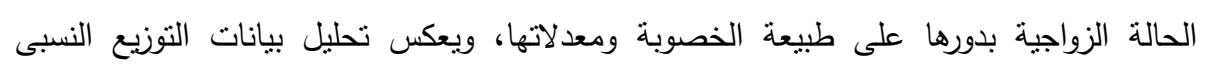

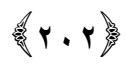


للسكان بحسب الحالة الزواجية كما يتضح من تحليل شكل رقم (9) ارتفاع المتوسط العام لنسبة

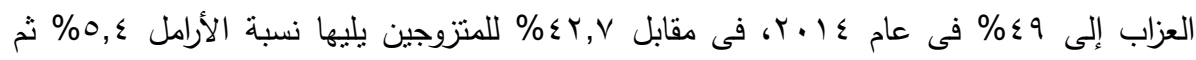

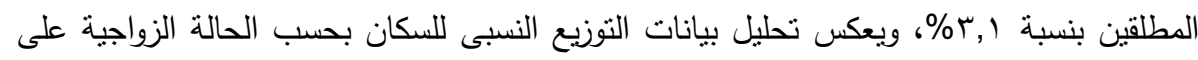

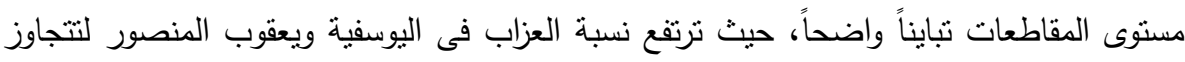

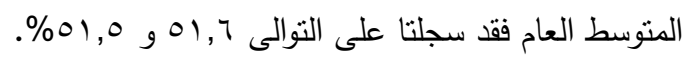

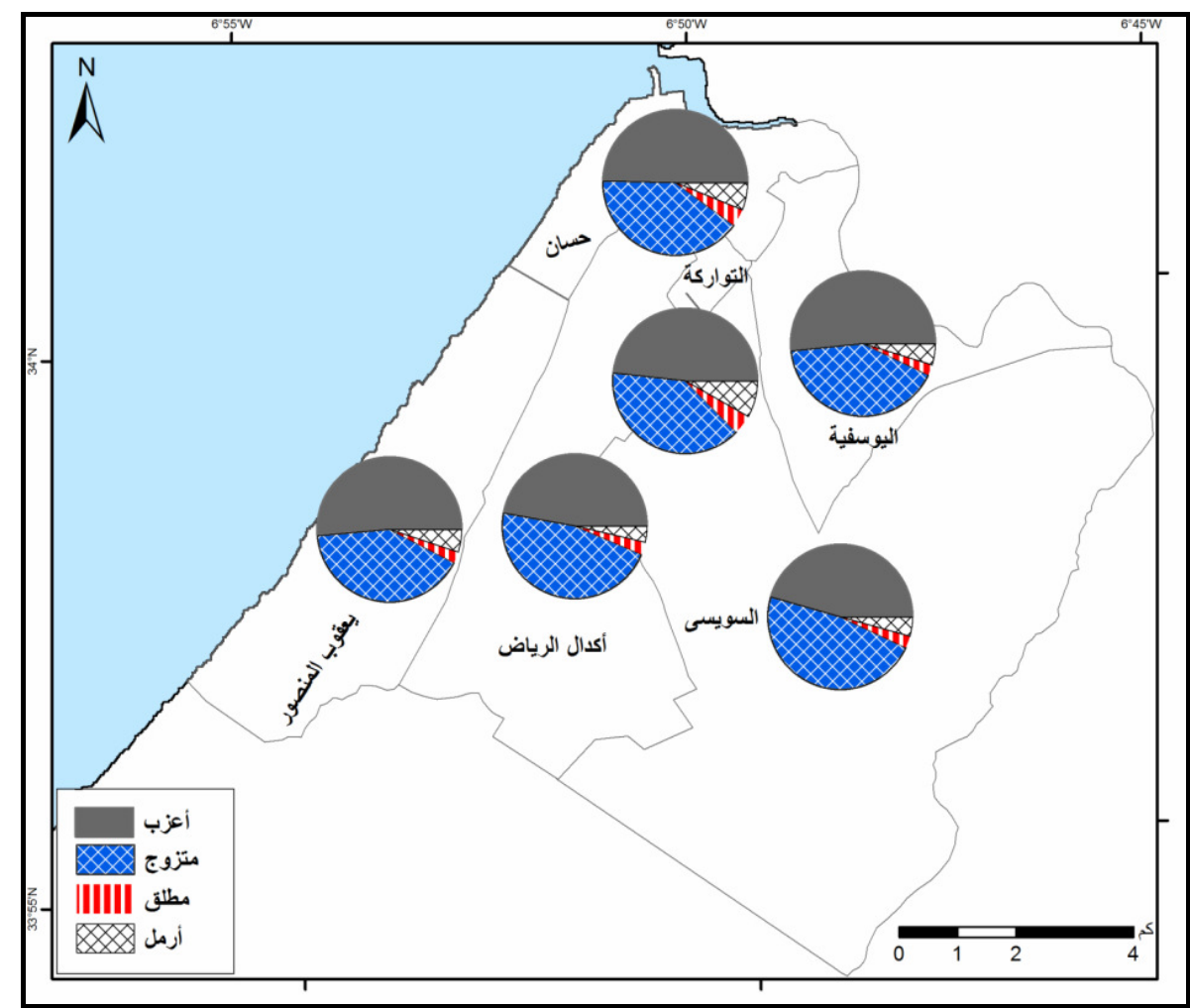

شكل (9) : نوزيع السكان طبقاً للحالة الزواجية على مستوى مقاطعات الرباط ـ ( ـ ؟.

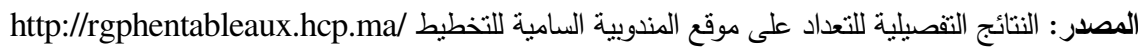

بينما سجلت أدنى نسبة فى مقاطعة السويسى بلغت 7 ؛ ؛ \%، كما عكست أيضاً نسبة المتزوجين

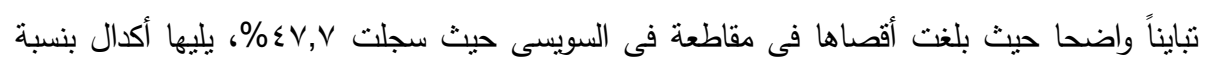

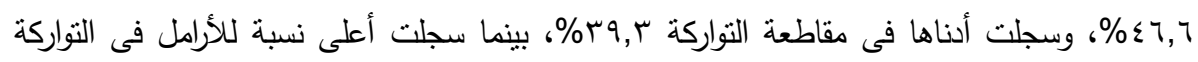

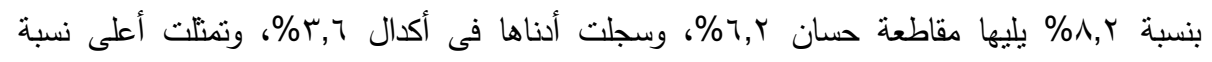

$$
\text { 受r・r薯 }
$$




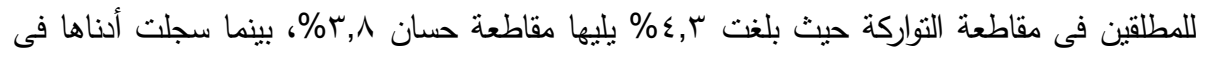

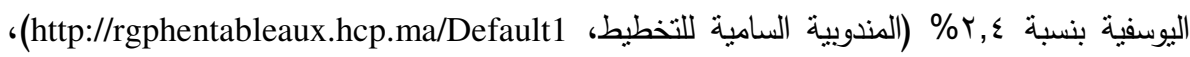
ويتضح مما سبق تثابه كل من يعقوب المنصور واليوسفية فى خصائص الحالة الزواجية.

يعد التعليم متغير اجتماعى هام يلعب دوراً بارزاً فى تشكيل العديد من الخصائص الديموجرافية

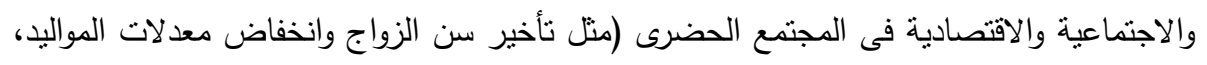

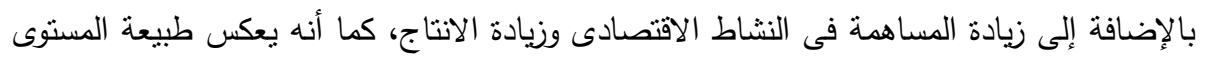

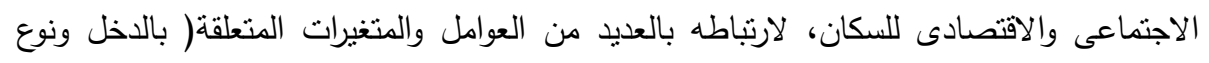

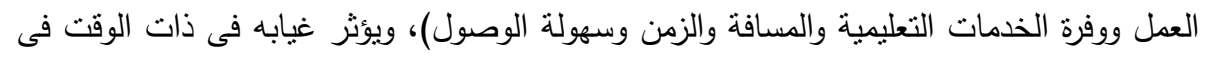
انتتار العديد من مشكلات (الأمية و البطالة وارتفاع معدلات الوفيات و انتشار الأمراض...إلخخ).

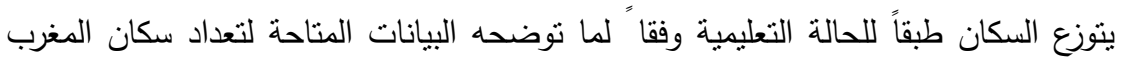
عام ع ا.ب بين مرحلة ما قبل الدراسة والمرحلة الإبتدائية ثم المرحلة الإعدادية والمرحلة الثانوية

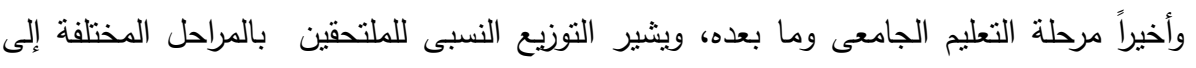

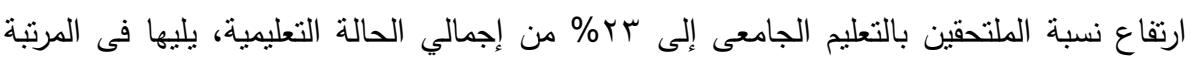

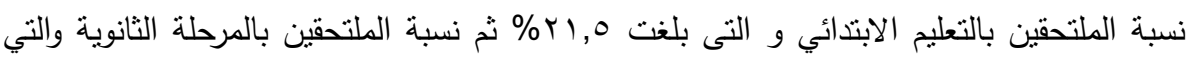

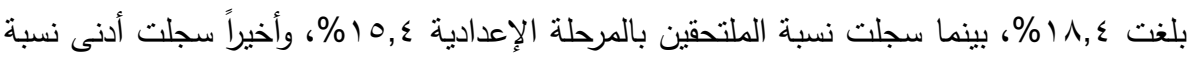

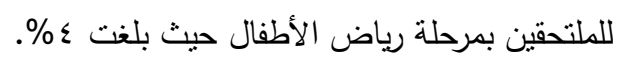
بينما يشير تحليل بيانات التوزيع النسبى لسكان المقاطعات فى الرباط طبقاً للحالة التعليمية بلفية

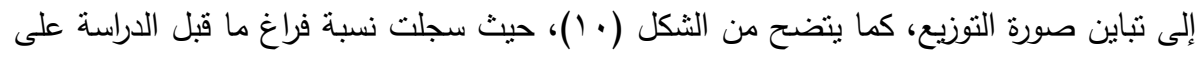

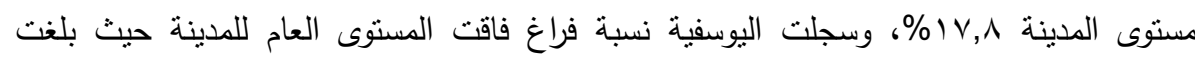

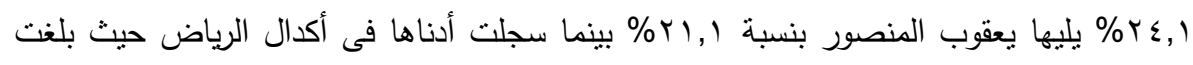

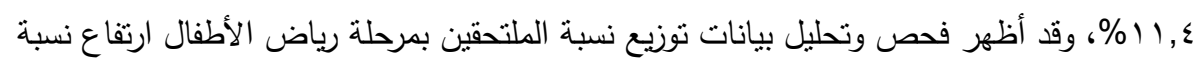

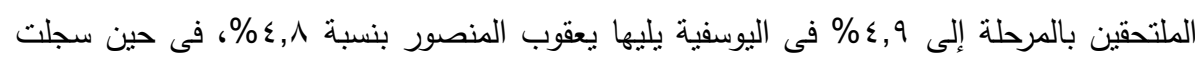

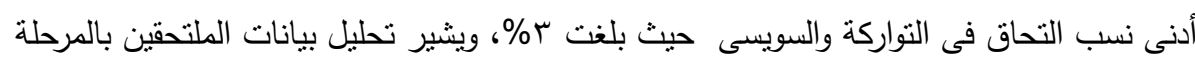

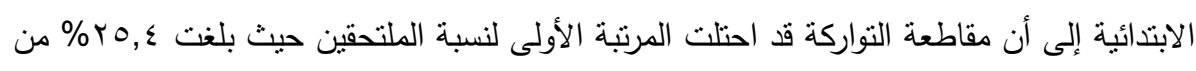

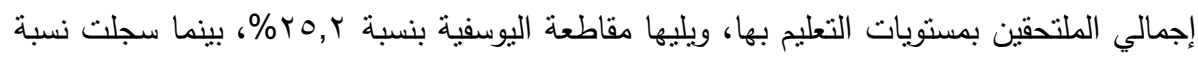

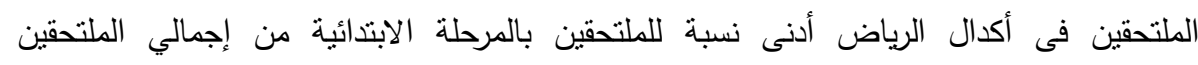

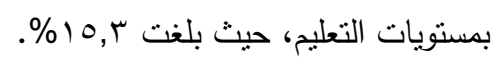




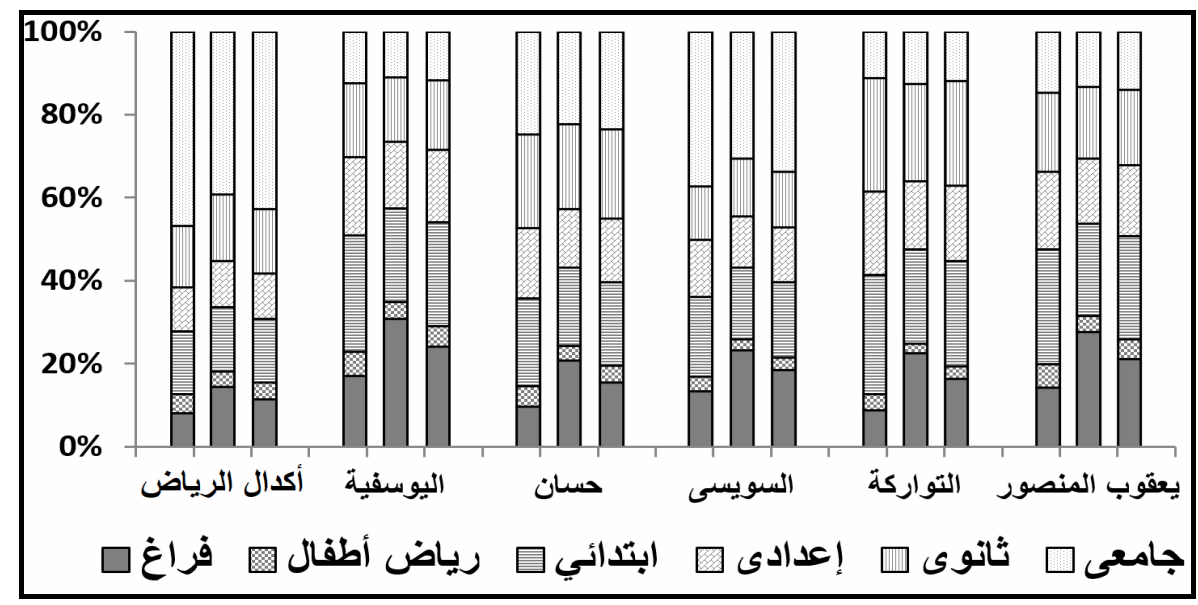

شكل ( • 1) : التوزيع النسبى للسكان طبقاً للحالة التعليمية على مستوى مقاطعات الرباط ـ ا ـ ؟.

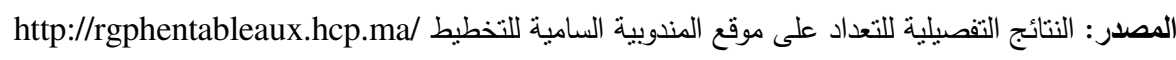

كما حافظت مقاطعة التواركة على صدارة التزتيب لنسبة الملتحقين بالمستوى الثانى من التعليم فى

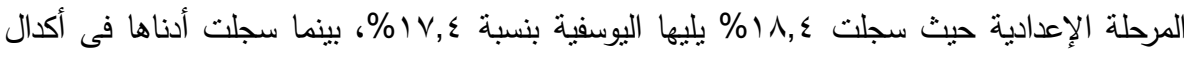

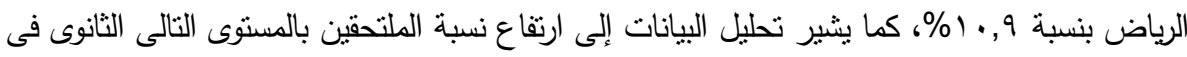

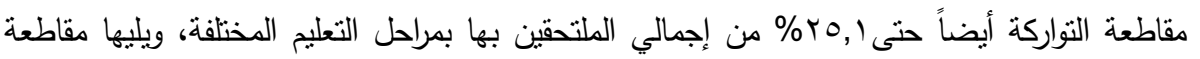

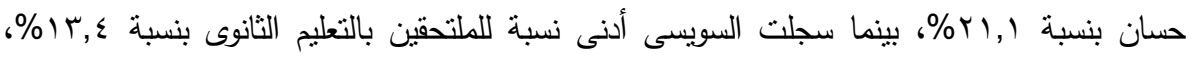

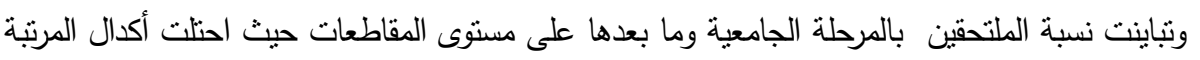

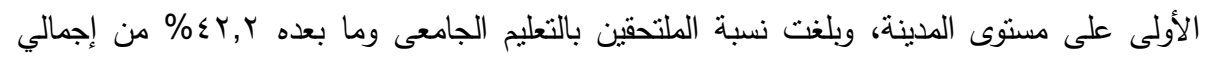

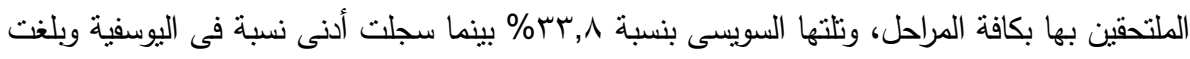

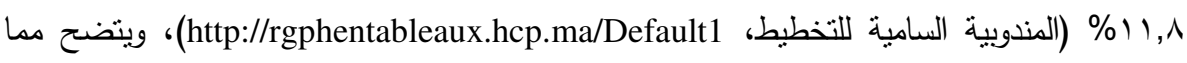

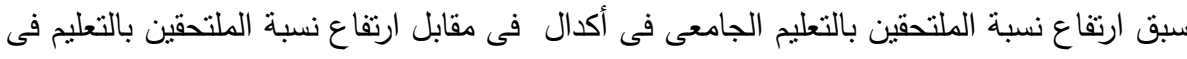

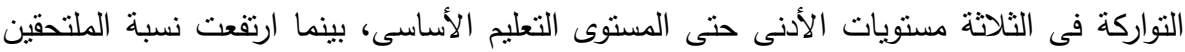

$$
\text { برياض الأطفال ومن هم خارج التعليم لفراغ ما قبل الدراسة فى حئ الئى اليوسفية. }
$$

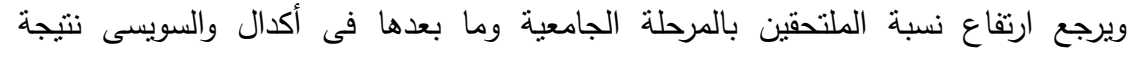

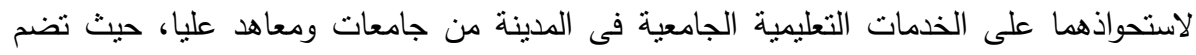
أكدال فرع جامعة محمد الخامس وكلياتها (الآداب للعلوم الانسانية وكلية العلوم القانونية

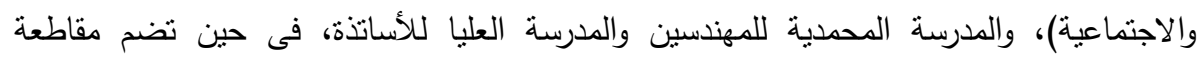
السويسى العديد من الكليات والمعاهد العليا والاسكان الجامعى الحكومي والخاص، ويتركز معظمها ولئه 
كما اتضح فى الزيارة الميدانية فى حى مدينة العرفان، وهو حى وظيفته تعليمية بشكل أساسي، فهو

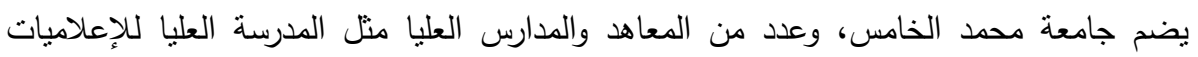
وتحليل النظم والمدرسة العليا لأساتذة التعليم الفنى ومعهد الدراسات الافريقية.

\section{ب الخصائص الاقتصادية )}

تتتاول دراسة الخصائص الاقتصادية كل ما يخص التركيب الإقتصادى للسكان، ولا شك أن

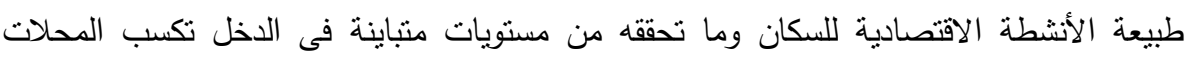

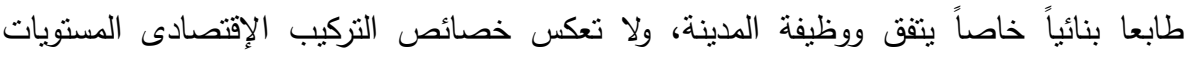

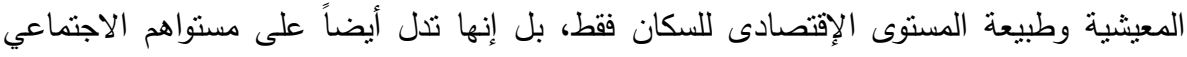

$$
\text { ومدى حضريتهم (حزين، } 997 \text { 19، ص سب (r). }
$$

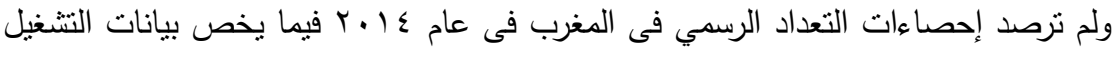

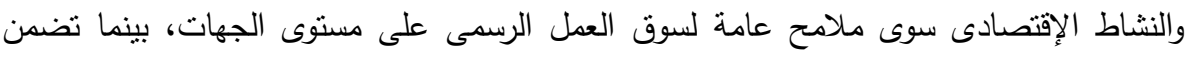

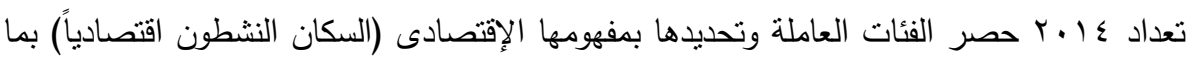
فوق 0اسنة حتى •ج سنة، ويشير تحليل بيانات النعداد إلى أن حجم إجمالي السكان النشطين

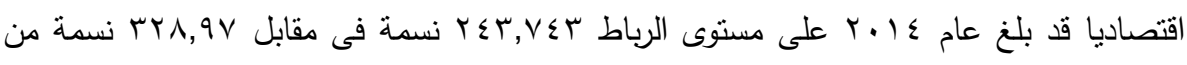

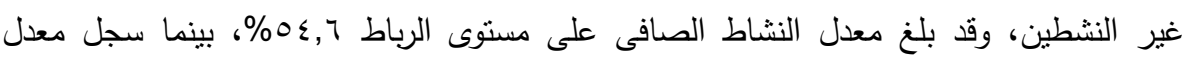

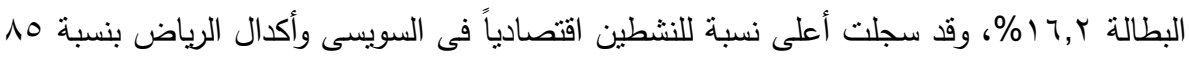

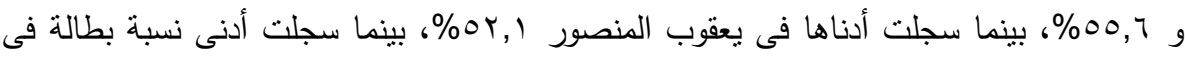

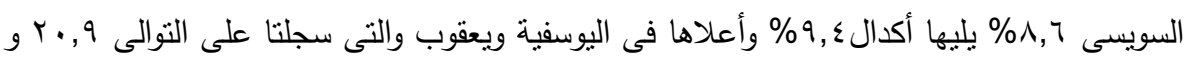

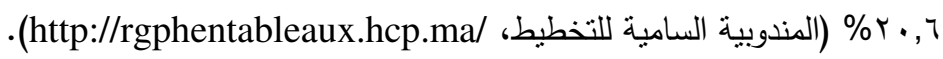

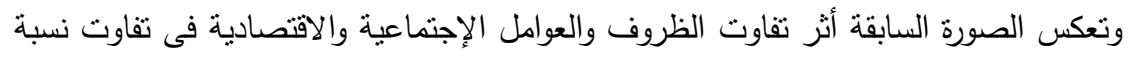
قوة العمل، وارتباط النسب المرتفعة بالمقاطعات التى يتوافر بها الخدمات الإدارية والحكومية ووظائف

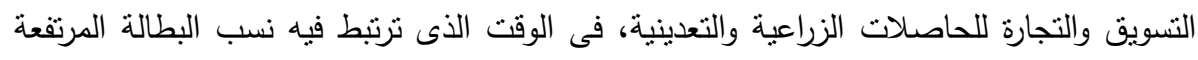
بالمناطق المنخفضة فى مسنويات التعليم العليا.

\section{أ- - توزيع السكان طبقاً لحالة العمل :}

يتوزع السكان بحسب حالة العمل على مستوى المقاطعات الرئيسية فى الرباط، وطبقاً لبيانات

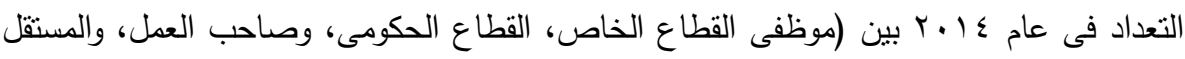
"من يعمل بنفسه وغير مستخدم لغيره"، وأخرى) كما يتضح من شكل (1) (1). 


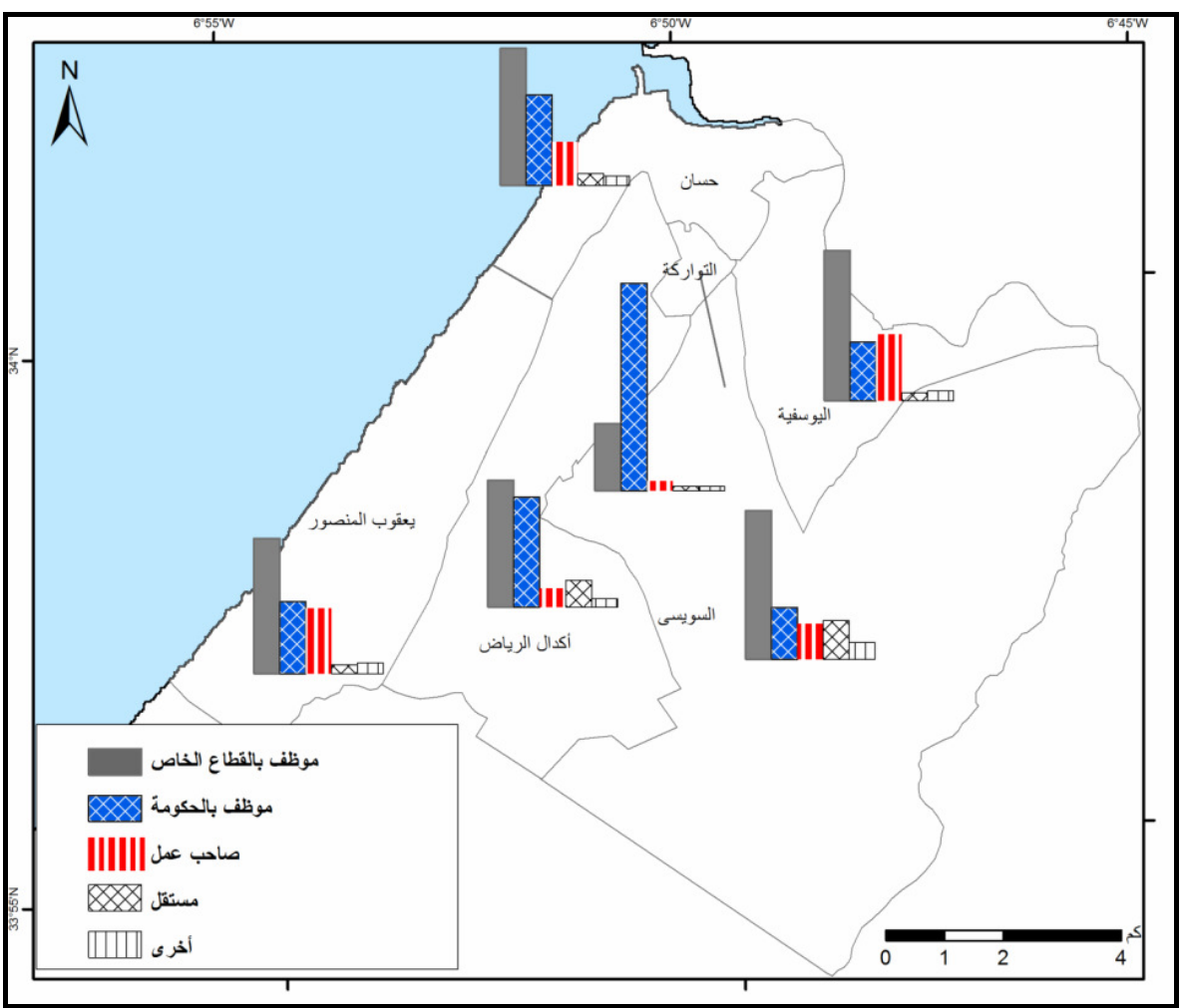

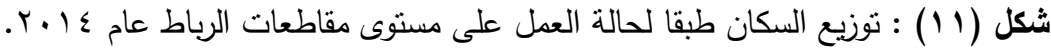
http://rgphentableaux.hcp.ma/ المصدر: النتائج التفصيلية للتعداد على موقع المندوبية السامية للتخطيط لهنيان

ويشير تحليل بيانات توزيع السكان طبقاً لحالة العمل على مستوى المدينة إلى ارتفاع نسبة

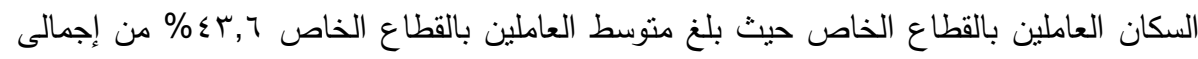

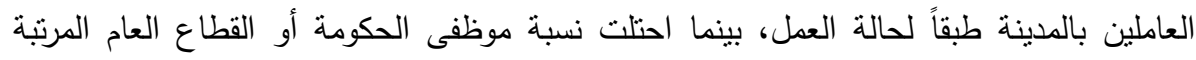

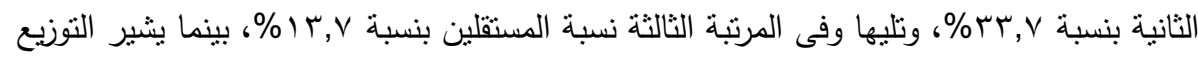

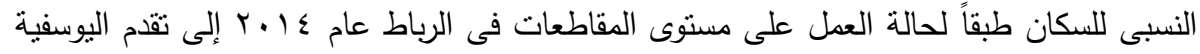

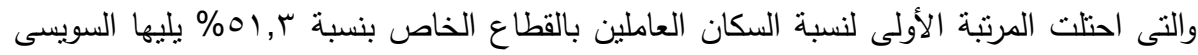

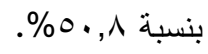

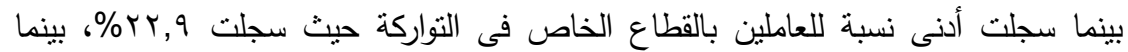

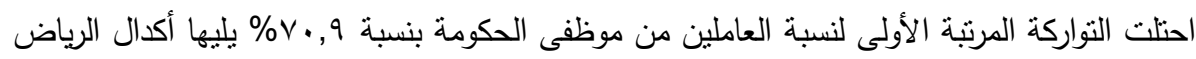

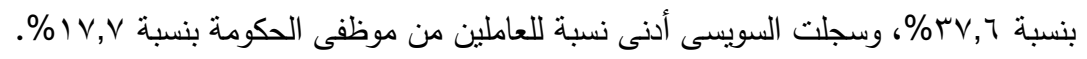
重r.V变 
وقد احتلت نسبة صاحب العمل المرتبة الثالثة طبقا لحالة العمل، وسجلت اليوسفية المرتبة

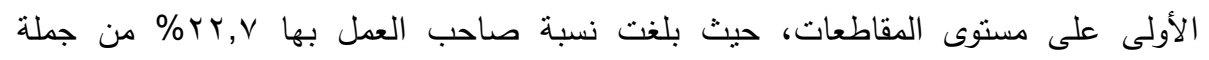

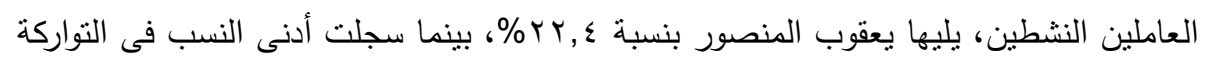

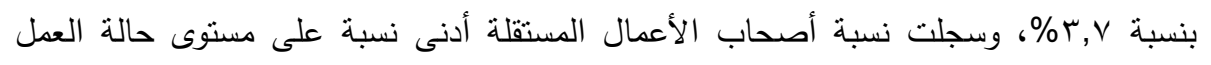

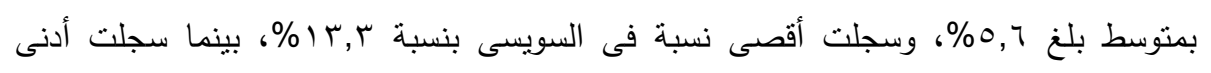

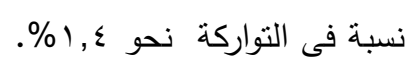

كما كثف الدراسة الميدانية تباين طبيعة نظام العمل طبقا لخصائص السكان الاجتماعية

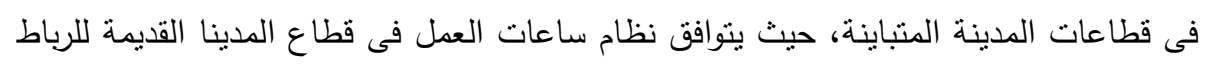

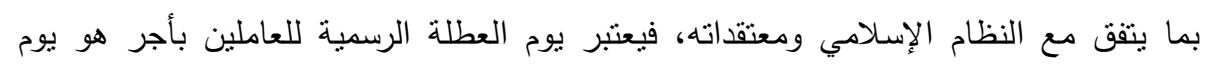

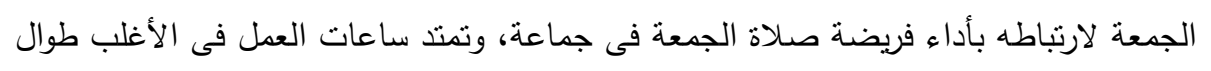

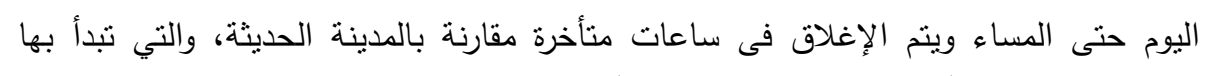

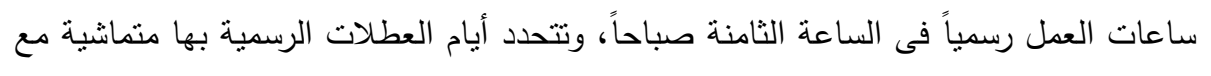

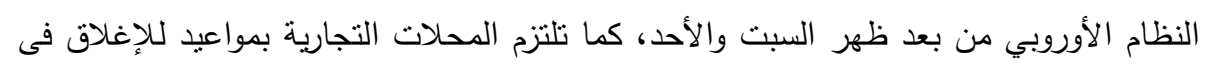

$$
\text { المساء التاسعة مساء. }
$$

\section{ب- تركيب السكان بحسب المهنة :}

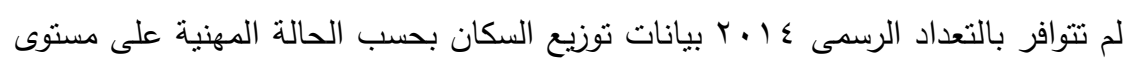
مدينه الرباط، بينما تشير الدراسات إلى اعتماد الرباط على قطاعات الأنشطة الاقتصادية

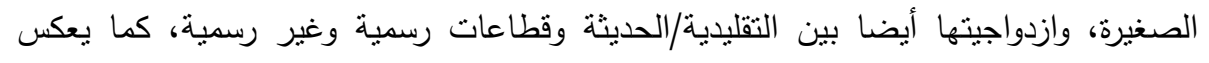

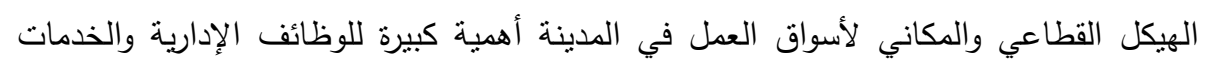

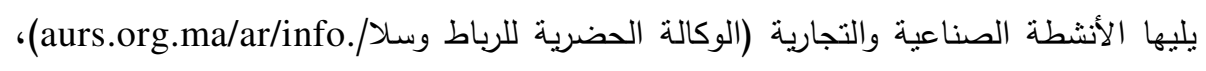

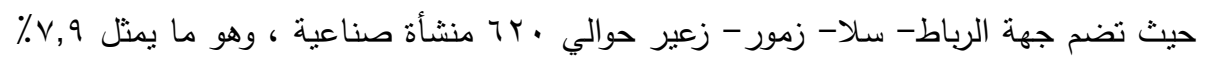

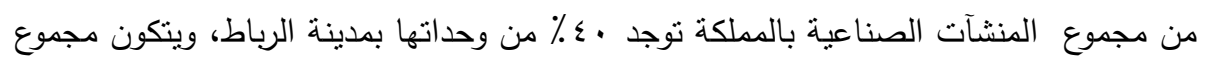

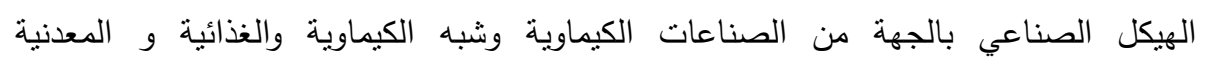

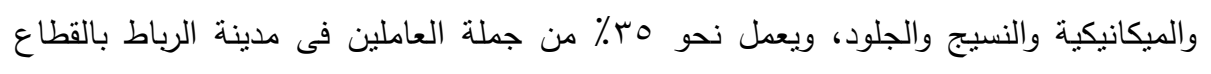

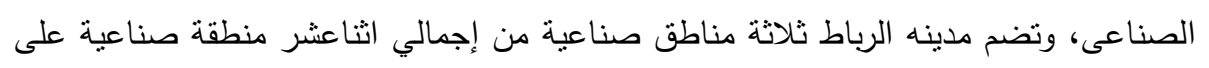

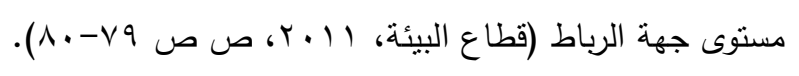

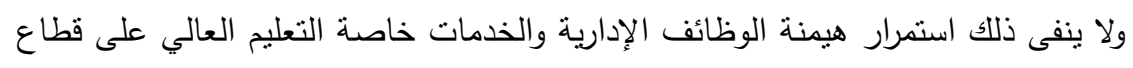

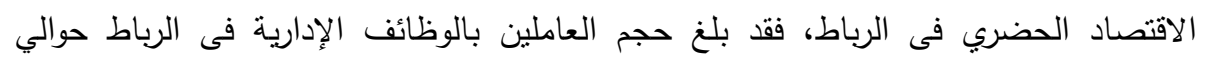




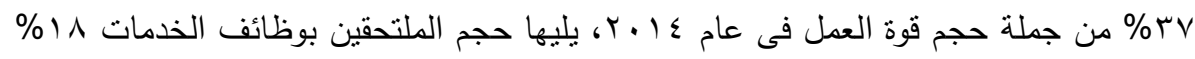
(الوكالة الحضرية للرباط وسل//aurs.org.ma/ar/info)، حيث أن بنية المنظومة الحضرية فى المغرب لا تزال تعتمد على فئتين من المدن أولهما المدن الاقتصادية التى تغذى الموارد

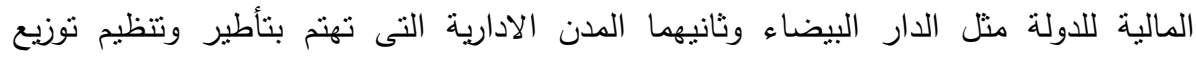

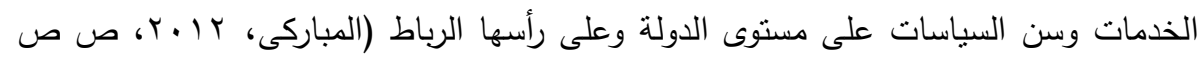

$(V Y-V)$

ويلتحق أغلب العاملين من السكان فى أحياء المنطقة الوسطى فى المدينة الحديثة فى

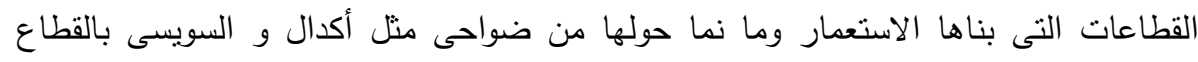

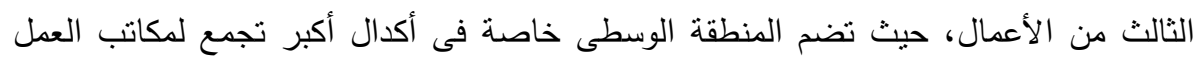

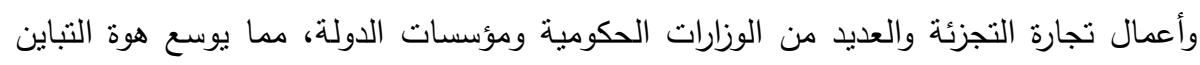

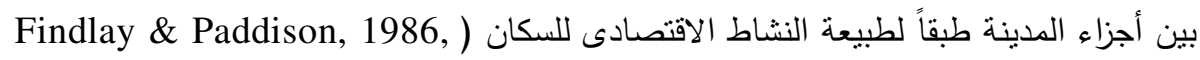

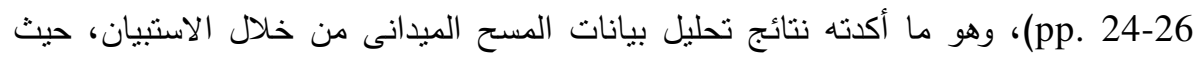

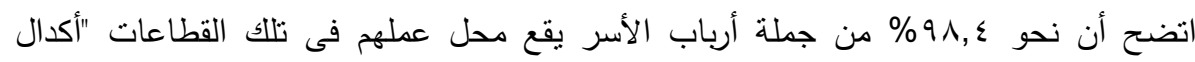

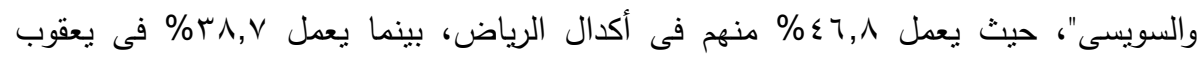

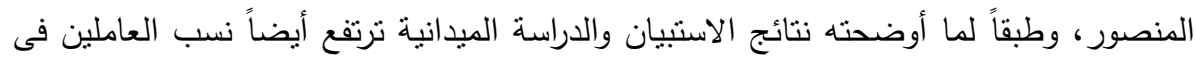
الاقتصاد الحضري غير الرسمى إلى ال1\% من حجم العينة فى الاستبيان، خاصة من الفئئات

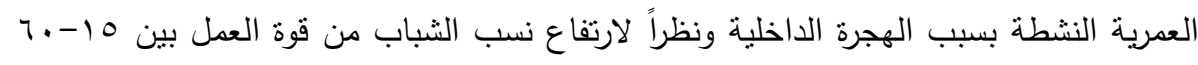

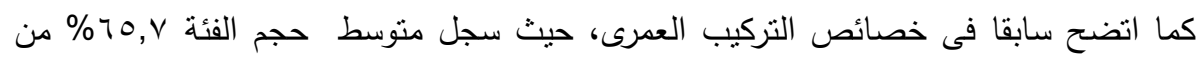

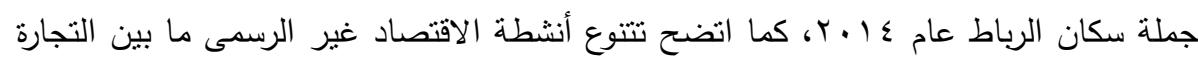

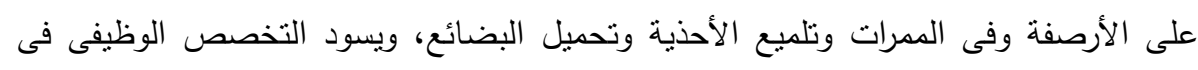

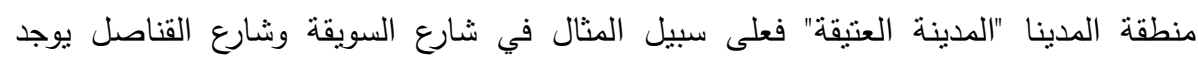

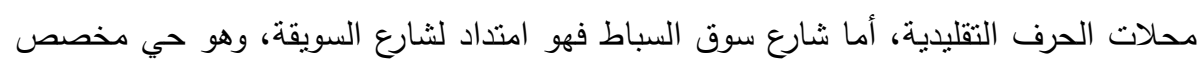

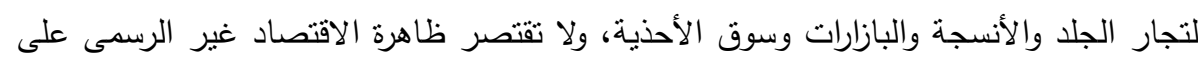

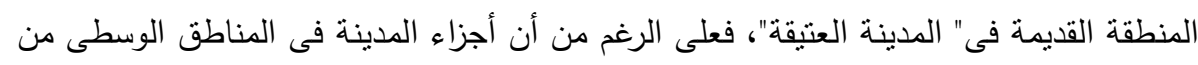

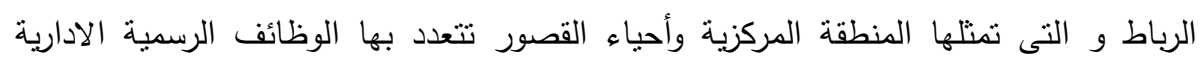

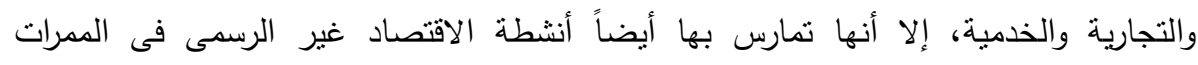

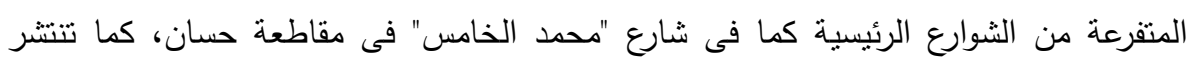

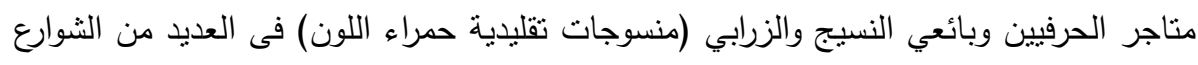
الرئيسية فى قطاعات المدينه. 
غابت بيانات منوسط الدخل الثهرى للفرد على مستوى المدينة عن البيانات الرسمية للتعداد، بينما أظهر فحص نتائج العينة من خلال الاستبيان، تباين واتساع الددى بين مستويات

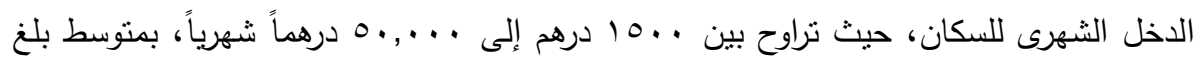

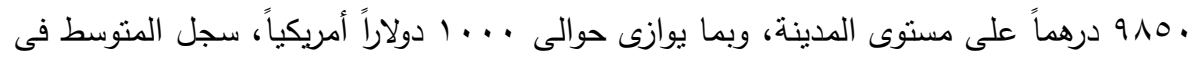

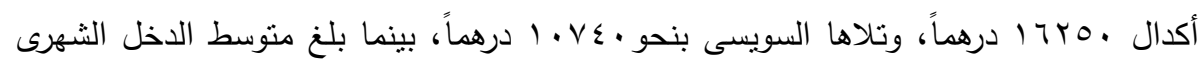

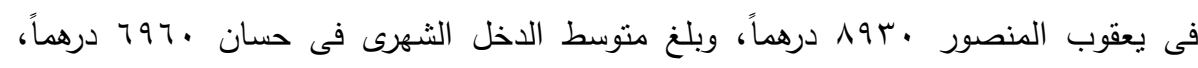

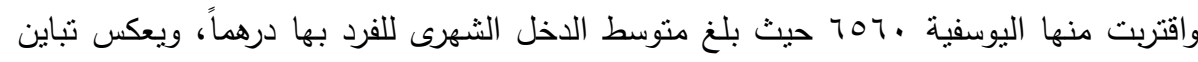

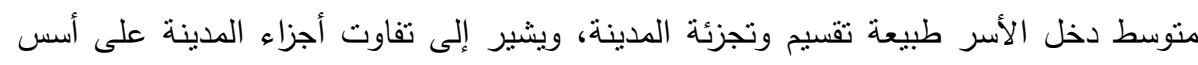

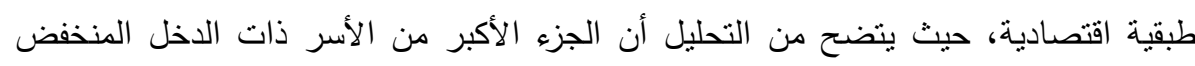

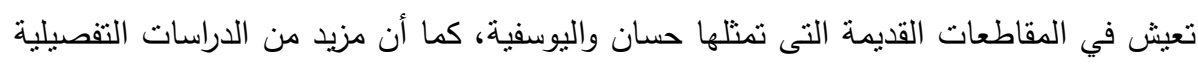
التى قد تجرى على الأحياء الفقيرة فى المدينة سوف تعكس مزيداً التفاوت واتساع الهوة.

\section{ثالثاً - تعليل التباين الأحادي لذصائص التركيب الإجتهماعى والاقتصادى والعمرانى}

\section{لمدينة الرباط :}

تسعى الدراسة لاستخدام تحليل التباين الأحادي للكثف عن تباين الخصائص الاقتصادية

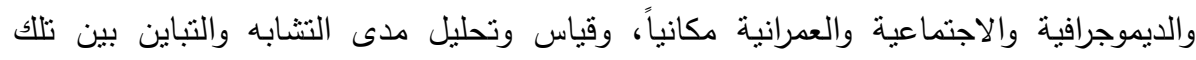

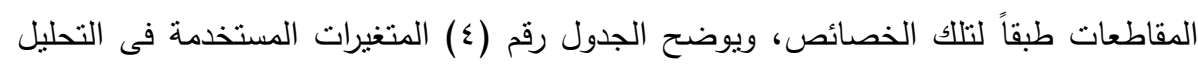
وتوصيفها فى برنامج SPSS. وقد تم اعتبار المقاطعات كمتغيرات مستقلة يتبع تغيرها تغير

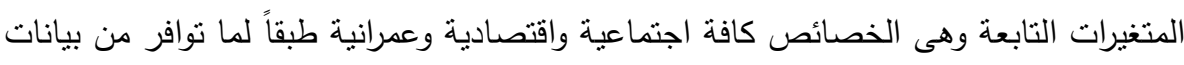

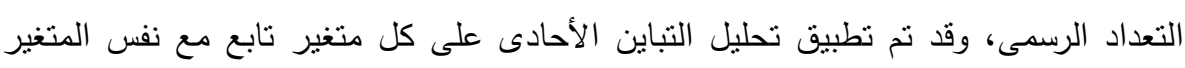

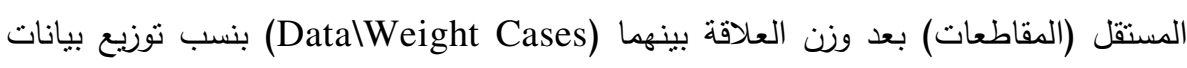

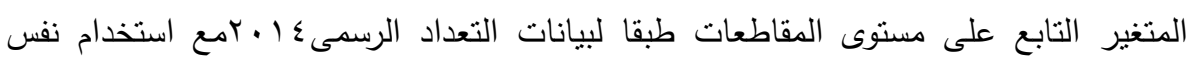
اختيارات التحليل (Model, Post Hoc, and Options) فى كل مرة، ثم تم تجميع نتائج

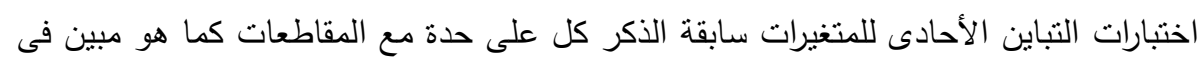
الجدول رقم (0) والذى يوضح نتائج اختبار between subject test. ويشير تحليل بيانات الجدول رقم (0) إلى وجود فروف فروف معنوية واضحة بين المقاطعات

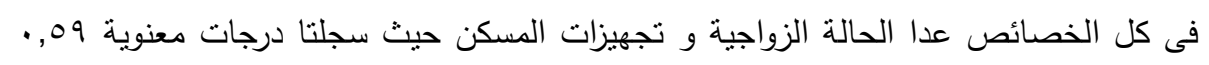
و ^ז, • على الترتيب، فيما حققت باقى الخصائص درجات معنوية أقل من ه. ., • مما يشير 
إلى وجود فروق معنوية بين المقاطعات فى هذه الخصائص وإن اختلف حجم تأثير كل منها، وهو ما يشير إلى مدى التفاوت بين المقاطعات فى كل خاصية على حدة، ولا تعنى تللك

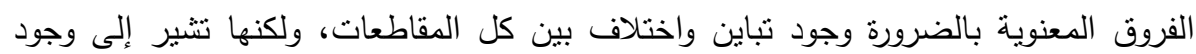
تباين بين اثثين من المقاطعات على الأقل ولتحديد مصادر الاختلاف أو المقاطعات المختلفة يمكن استخدام أسلوب المقارنات المتعدد والذى يعرف بالاختبارات البعدية (post Hoc) (أمين،

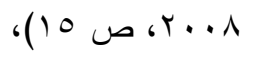

جلول ( ؛) : المتغيرات المستخدمة فى التحليل وتوصيفها فى برنامج SPSS.

\begin{tabular}{|c|c|c|c|}
\hline النوع & الكود & البيانات & المتغير \\
\hline \multirow{5}{*}{$\begin{array}{l}\text { Nominal } \\
\text { منغير تابع }\end{array}$} & 1 & فيلا & \multirow{5}{*}{ المسكن } \\
\hline & $r$ & منزل مستقل & \\
\hline & $r$ & شقة في مبنى & \\
\hline & $\varepsilon$ & إسكان جماعى & \\
\hline & 0 & أخرى & \\
\hline \multirow{3}{*}{$\begin{array}{l}\text { Nominal } \\
\text { متغبر تابع }\end{array}$} & 1 & مالك & \multirow{3}{*}{ الحيازة } \\
\hline & r & مستأجر & \\
\hline & $r$ & أخرى & \\
\hline \multirow{4}{*}{$\begin{array}{l}\text { Nominal } \\
\text { منغير تابع }\end{array}$} & 1 & أقل من · ا سنوات & \multirow{4}{*}{ المسكن } \\
\hline & $r$ & من · ا إلى . r سنة & \\
\hline & r & من ·. إلى .0 سنة & \\
\hline & $\varepsilon$ & أكثر من ·0 سنة & \\
\hline \multirow{3}{*}{$\begin{array}{l}\text { Nominal } \\
\text { متغبر تابع }\end{array}$} & 1 & المطبخ & \multirow{3}{*}{ تجهيزات } \\
\hline & $r$ & مرحاض & \\
\hline & $r$ & حمام أو دش & \\
\hline \multirow{7}{*}{$\begin{array}{l}\text { Nominal } \\
\text { متغير تابع }\end{array}$} & 1 & مياه جارية & \multirow{7}{*}{ العبكات } \\
\hline & r & الصرف الصحي & \\
\hline & r & غاز البيوتان & \\
\hline & $\varepsilon$ & كهرباء & \\
\hline & $\circ$ & الهاتف المنزلى & \\
\hline & \multirow{2}{*}{1} & الثاحنات العامة & \\
\hline & & للتخلص من النفايات & \\
\hline
\end{tabular}

\begin{tabular}{|c|c|c|c|}
\hline النوع & الكود & البيانات & المتفير \\
\hline \multirow{6}{*}{$\begin{array}{c}\text { Nominal } \\
\text { متغير مسنقل }\end{array}$} & 1 & أكدال الرياض & \multirow{6}{*}{ المقاطعة } \\
\hline & r & اليوسفية & \\
\hline & $r$ & حسان & \\
\hline & $\varepsilon$ & السويسي & \\
\hline & 0 & التواركة & \\
\hline & 1 & يعقوب المنصور & \\
\hline \multirow{4}{*}{$\begin{array}{l}\text { Nominal } \\
\text { متير تابع }\end{array}$} & 1 & عازب & \multirow{4}{*}{ الزواجية } \\
\hline & r & منزوج & \\
\hline & $r$ & مطلق & \\
\hline & $\varepsilon$ & أرمل & \\
\hline \multirow{6}{*}{$\begin{array}{l}\text { Nominal } \\
\text { ثنغير تابع }\end{array}$} & 1 & فراغ & \multirow{6}{*}{ التطليمبة } \\
\hline & r & رياض أطفال & \\
\hline & r & ابتدائي & \\
\hline & $\varepsilon$ & إعدادى & \\
\hline & 。 & ثنانوى & \\
\hline & 7 & جامعى & \\
\hline \multirow{5}{*}{$\begin{array}{l}\text { Nominal } \\
\text { مثغير تابع }\end{array}$} & 1 & موظف في القطاع الخاص & \multirow{5}{*}{ حالة العمل } \\
\hline & r & موظف في القطاع العام & \\
\hline & $r$ & صاحب عمل & \\
\hline & $\varepsilon$ & مستقل & \\
\hline & 0 & أخرى & \\
\hline \multirow{2}{*}{$\begin{array}{l}\text { Nominal } \\
\text { ثتغير تابع }\end{array}$} & 1 & السكان النشطون & \multirow{2}{*}{ الاقتصادي النشاط } \\
\hline & r & الغير نشطين & \\
\hline
\end{tabular}


جدول (•) : نتائج اختبار between subject test.

\begin{tabular}{|c|c|c|c|c|}
\hline مدى وضوح التأثير & حجم التأثير & P-Value & قيمة F المحسوية & المتغير \\
\hline$\cdot, 9 \cdot 9$ & $\cdot, \cdots 9$ &.,$\ldots$ & r, & الفئات العمرية \\
\hline$\cdot, Y V_{1}$ & $\cdot, \cdots r$ & $\cdot, 091$ & $\cdot, v \leq r$ & الحالة الزواجية \\
\hline $1, \ldots$ & $\cdot, \cdot \leq 0$ & $\cdot, \cdots$ & $1 \mathrm{~V}, .01$ & الحالة التعليمية \\
\hline 1 & $\cdot, 1 \leq 0$ & $\cdot, \ldots$ & $\varepsilon \cdot, \leqslant 99$ & حالة العمل \\
\hline$\cdot, 9 \wedge r$ & $\cdot, \cdot 1 \pi$ & $\cdot, \cdots$ & $\varepsilon, 190$ & حالة النشاط الاقتصادى \\
\hline $1, \ldots$ & $\cdot, 11 \pi$ & $\cdot, \cdots$ & $10,1 \pi$. & نمط المسكن \\
\hline $1, \ldots$ & $\cdot, \mid M$ & $\cdot, \cdots$ & $1 \mathrm{~V}, 90 \mathrm{~V}$ & نمط الحيازة \\
\hline $1, \ldots$ & $\cdot$, ro. & $\cdot, \cdots$ & $r 9,9.9$ & عمر المسكن \\
\hline • rN & $\cdot, \ldots r$ & • rAT & $1, .01$ & تجهيزات المسكن \\
\hline$\cdot, 99 \wedge$ & ., & $\cdot, \cdots$ & $7, V \Gamma V$ & شبكات المرافق العامة \\
\hline
\end{tabular}

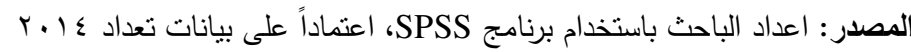
(المندوبية السامية للتخطيط http://rgphentableaux.hcp.ma/Default1)

لتجيب الدراسة على تساؤل ما هى المقاطعات التى تختلف فيما بينها طبقاً لكل متغير

(ديموجرافى واجتماعى واقتصادى وعمرانى)، وكما يتضح من تحليل بيانات جدول (T) وما توضحه نتائج اختبار pair wise test للكثف عن إذا ما كان هناك فرق معنوى فى متغير معين من المتغيرات التابعة ما بين المقاطعات وبعضها عن طريق استيضاح العلاقة بين كل مقاطعة وأخرى على حده. وقد تم ادخال البيانات للاختبار واستخراج قيمة الفروق المتوسطات وقيم "F" المحسوبة ودرجة المعنوية ”P-Value" لكافة المتغيرات على مستوى المقاطعات طبقاً للاختبار ، وتمثل ه.,. • القيمة القياسية لدرجة المعنوية وما فوقها يعنى نطابق المتغيرات وعدم وجود تباين فى مئى مقابل الانخفاض عن القيمة القياسية فإنه يشير إلى التباين، ويشير تحليل بيانات جدول (†) وجود فروق فى سلوك المتغيرات ما بين كل مقاطعة وأخرى. وقد أظهر التحليل تبايناً فيما بين المقاطعات فى بعض المتغيرات مثل الفئة العمرية، والذى سجل درجات معنوية أقل من هـ هـ ـ. فيما بين مقاطعة اليوسفية وكل من حسان والسويسى والتواركة، مما يعنى تفاوتاً بين اليوسفية

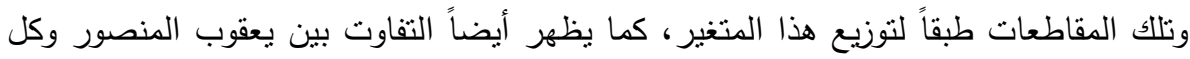
من السويسى والتواركة فى نفس المتغير إذ سجل التحليل درجات معنوية أقل من ه ه., . . 


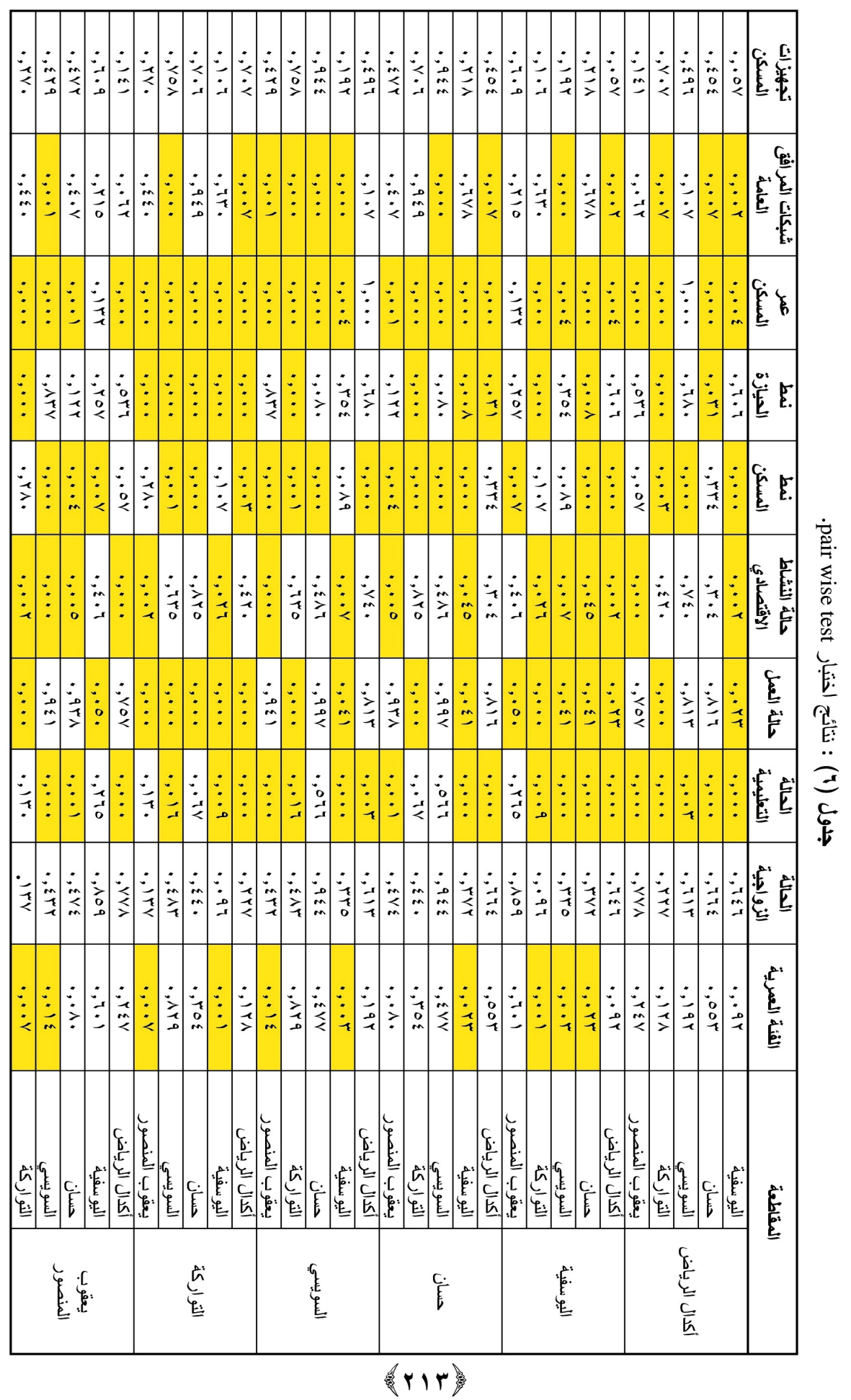


كما أظهر التحليل لمتغير الحالة التعليمية تبايناً بين معظم المقاطعات إذ لم بسجل التحليل قيماً لدرجات المعنوية أكبر ه.., • سوى فى حسان مع كل من السويسى والتواركة، وكذا بين يعقوب المنصور وكل من اليوسفية والتواركة، وهى المقاطعات التى أظهر التحليل عدم وجود فروق معنوية بينها طبقاً للحالة التعليمية.

بينما أظهر فحص مدى تباين المقاطعات طبقاً لمتغير حالة العمل نباين مقاطعتى اليوسفية والتواركة مع كافة المقاطعات، بينما تثابهت كل من أكدال الرياض وحسان والسويسى لئى وبعقوب المنصور طبقاً لحالة العمل حيث سجلت قيم معنوية أكبر من 0 ., .

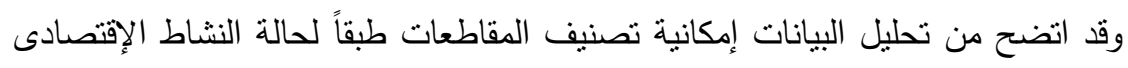
إلى فئتين متباينتين، تضم الفئة الأولى مجموعة مقاطعات اليوسفية ويعقوب والتى حققتا درجة معنوية بلغت ع , • بينهما، فى الوقت الذى تباينتا فيه مع كافة المقاطعات الأخرى محققة درجات

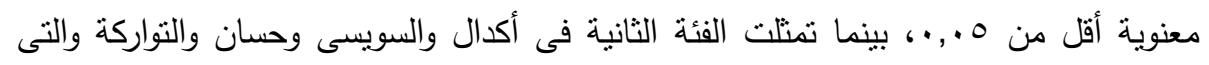
سجلت درجات معنوية تراوحت بين ז, • و ^, • فيما بينهم، فى الوقت الذى سجلت فيه درجات معنوية أقل من 0 . . • مع اليوسفية ويعقوب. ويشير فحص تباين المقاطعات طبقاً للمتغيرات العمرانية، أن المتغير الأول وهو نمط هن المسكن قد دل تحليل بياناته على تشابه مقاطعة أكدال الرياض مع كل من مقاطعتى حسان ويعقوب المنصور حيث سجلت درجة معنوية فوق ه.., •، وقد جاءت على التوالى مع حسان

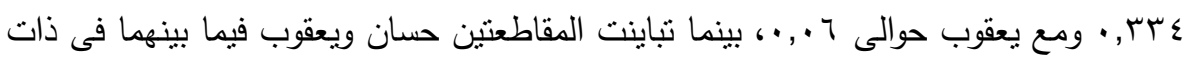
الوقت بدرجة معنوية بلغت 0 . ., . ، كما تشابهت اليوسفية مع كل من السويسى والتواركة حيث سجلت درجة معنوية 9 .,. . مع السويسى و ا ,. مع التواركة، بينما ثناينت السويسى والتواركة فيما بينهما فى ذات الوقت حيث سجلت ا +.,.، وفى المقابل تشابهت مقاطعتى يعقوب والتواركة بدرجة معنوية بلغت ^ ب, •. بينما أظهر تحليل بيانات نمط الحيازة تباين التواركة عن باقى المقاطعات حيث حققت قيم

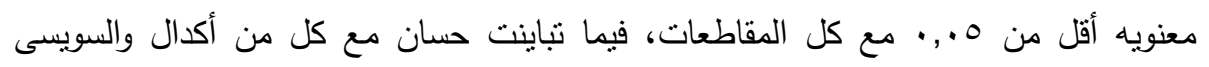

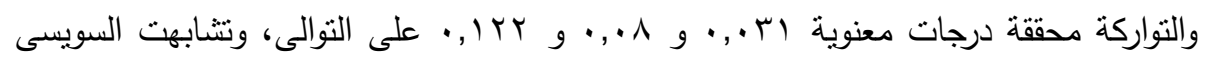
ويعقوب المنصور مع باقى المقاطعات كل على حده ما عدا النواركة. 
وبالنسبة لعمر المسكن فقد اتضح من تحليل البيانات تثابه أكدال مع السويسى حيث سجلت فيما بينها درجة معنوية .,1، وتباينت كل منهما فى ذات الوقت مع بقية المقاطعات حيث سجلت كل منهما قيماً لدرجات المعنوية أقل من ه. ., • مع باقى المقاطعات، كما تثابهت اليوسفية مع يعقوب المنصور حيث سجلتا درجة معنوية بr., ,· وتباينت كل منهما مع بقية

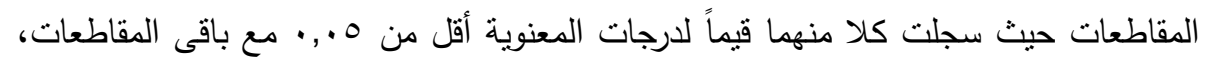
كما تباينت حسان والنواركة عن كل المقاطعات.

وقد اتضح من تحليل تباين المقاطعات طبقاً للإدماد بشبكات المرافق العامة إمكانية تصنيف المقاطعات إلى فئتنين متباينتين، تضم الفئة الأولى مقاطعات أكدال الرياض لهن

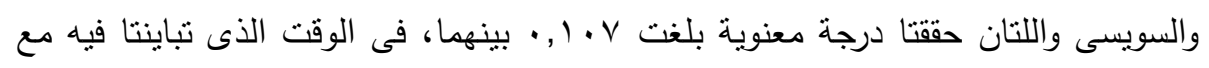

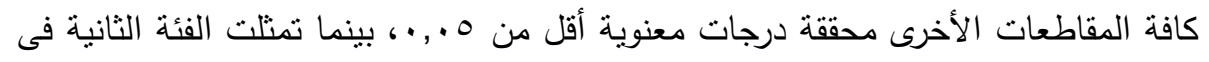
مقاطعات اليوسفية ويعقوب المنصور وحسان والتواركة والتى سجلت درجات معنوية أكبر

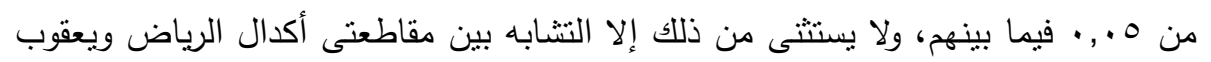
المنصور بدرجة معنوية 7 •,.,

وبشكل عام يبرز التشابه بين مقاطعتى أكدال الرياض والسويسى، فكما يتضح من البيانات

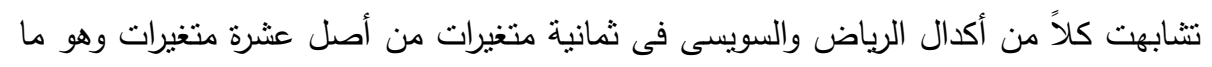
يعكس تقارب خصائصها، كما هو الحال فى النتابه بين مقاطعتى يعقوب المنصور واليوسفية واللتان تثابهتا فى ثمانية متغيرات أيضاً وهو ما يعكس تقارب خصائصهما، في ذات ذات الوقت الذى سجلت فيه أقصى درجة تباين بين حسان واليوسفية فقد اقتصر التشابه على ثلاثة متغيرات فقط وهى متغيرات (الحالة الزواجية وتجهيزات المسكن)، حيث تشابهت فى كل المقاطعات بالإضافة إلى متغير "تثبكات المرافق العامة" والذى سجل درجة معنوية TV^, · بمعنى انساع درجة التباين بين حسان واليوسفية. بينما جاء فى المرتبة الثانية من ناحية التباين مقاطعة اليوسفية وكل من أكدال

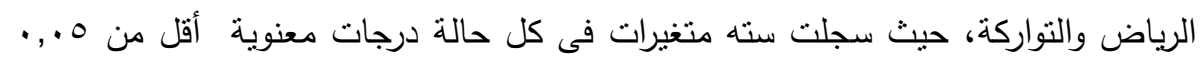

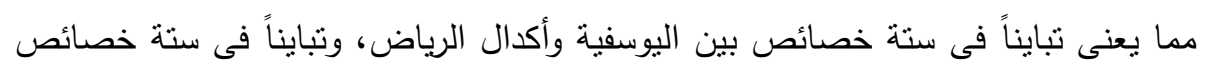

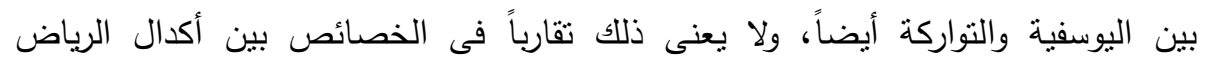
والتواركة، إذ سجل التحليل تبايناً فى خمسة خصائص حققت درجات معنوبة أقل من ه هـ ـ. . ، طبقاً لما أظهرته نتائج التحليل السابق. 


\section{رابعاً - تحليل التباين المتعدد لذصائص التركيب الإجتهاعى والاقتصادى والعهرانى}

لمدينة الرباط :

تسعى دراسة نحليل التباين المتعدد إلى الكثف عن مدى تأثير الخصائص

الاجتماعية والاقتصادية على خصائص البيئة الحضرية العمرانية، اعتماداً على بيانات

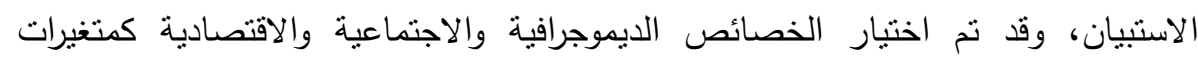

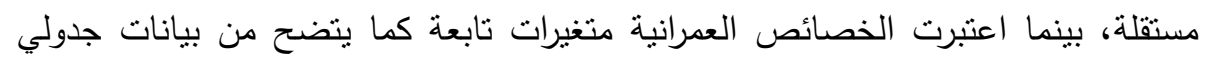

$$
\text { . }\left(\varphi^{-\gamma}\right) ،(\mid-\gamma)
$$

$$
\text { (الخصائص الديموجرافية والاجتماعية والاقتصادية). : المتخيرات المستلة المستخمة فلتيل }
$$

\begin{tabular}{|c|c|c|c|}
\hline النوع & الكود & البيانات & المتفيز \\
\hline \multirow{7}{*}{ Ordinal } & 1 & غير هتعلم & \multirow{7}{*}{ مسنوى التعليم } \\
\hline & r & يقرأ ويكتب & \\
\hline & $r$ & ابتدائى & \\
\hline & $\varepsilon$ & اعدادى & \\
\hline & o & ثانوى & \\
\hline & 7 & جامعى & \\
\hline & v & فوف الجامعى & \\
\hline \multirow{4}{*}{ Ordinal } & 1 & العربية & \multirow{4}{*}{ اللغات } \\
\hline & r & الفرنسية & \\
\hline & $r$ & الإنجليزية & \\
\hline & $\varepsilon$ & لغات أخرى & \\
\hline \multirow{5}{*}{ Ordinal } & 1 & موظف حكومى & \multirow{5}{*}{ طبيعة } \\
\hline & r & موظف بالقطاع الخاص & \\
\hline & $r$ & صاحب عمل & \\
\hline & $\varepsilon$ & تدبير منزلى & \\
\hline & o & أخرى & \\
\hline Scale & & & حجم الأسرة \\
\hline
\end{tabular}

\begin{tabular}{|c|c|c|c|}
\hline النوع & الكود & البيانات & المتغير \\
\hline \multirow{2}{*}{ Ordinal } & 1 & ذكر & \multirow{2}{*}{ النوع } \\
\hline & r & انثى & \\
\hline \multirow{2}{*}{ Ordinal } & 1 & الرباط & \multirow{2}{*}{ محل الميلاد } \\
\hline & r & مدينة أخرى & \\
\hline \multirow{4}{*}{ Ordinal } & 1 & أعزب & \multirow{4}{*}{ الزواجية } \\
\hline & r & منزوج & \\
\hline & $r$ & مطلق & \\
\hline & $\varepsilon$ & 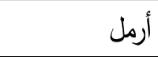 & \\
\hline \multirow{7}{*}{ Ordinal } & 1 & أكدال الرياض & \multirow{7}{*}{ الإقامة } \\
\hline & r & اليوسفية & \\
\hline & $r$ & حسان & \\
\hline & $\varepsilon$ & السويسى & \\
\hline & 0 & الثواركة & \\
\hline & 7 & يعقوب المنصور & \\
\hline & $\mathrm{v}$ & مدينة أخرى & \\
\hline \multicolumn{3}{|c|}{ منل منغير محل الإقامة } & محل العمل \\
\hline Scale & & & الدخل \\
\hline
\end{tabular}


جدول (V-ب) : المتغيرات التابعة المستخدمة فى التحليل (الخصائص العدرانية).

\begin{tabular}{|c|c|c|c|c|c|c|c|}
\hline النوع & الكود & البيانات & المتغير & النوع & الكود & البيانات & المتغير \\
\hline \multirow{6}{*}{ Ordinal } & 1 & مدرسة إبتدائى & \multirow{6}{*}{ تعليمة } & \multirow{3}{*}{ Ordinal } & 1 & تمليك & \multirow{3}{*}{ طبيزة } \\
\hline & r & مدرسة إعدادى & & & r & إيجار & \\
\hline & $r$ & مدرسة ثانوى & & & $r$ & أخرى & \\
\hline & $\varepsilon$ & كلية & & \multirow{5}{*}{ Ordinal } & 1 & فيلا & \multirow{5}{*}{ السكن } \\
\hline & 0 & أكثر من خدمة & & & r & منزل مستقل & \\
\hline & 7 & أخرى & & & $r$ & شقة في مبنى & \\
\hline Scale & \multicolumn{3}{|c|}{ المسافة من اقرب خدمة تعليمية } & & $\varepsilon$ & إسكان جماعى & \\
\hline \multirow{6}{*}{ Ordinal } & 1 & وحدة صحية & \multirow{6}{*}{ حدمة } & & 。 & أخرى & \\
\hline & r & مستشفى حكومى & & \multirow{2}{*}{ 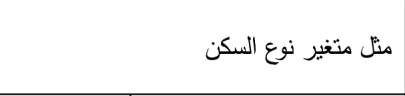 } & \multirow{2}{*}{\multicolumn{2}{|c|}{ مثل متغير نوع السكن }} & \multirow{2}{*}{ فلى الحى الثائع } \\
\hline & r & مستشفى خاصة & & & & & \\
\hline & $\varepsilon$ & عيادة & & Scale & & & عدد الغرف \\
\hline & 0 & أكثر من خدمة & & Scale & & & عدد الطوابق \\
\hline & 7 & أخرى & & \multirow{4}{*}{ Ordinal } & 1 & سكنى & \multirow{4}{*}{ الطابق الارضى } \\
\hline Scale & \multicolumn{3}{|c|}{ المسافة من اقرب خدمة صحية } & & r & تجارى & \\
\hline \multirow{7}{*}{ Ordinal } & 1 & سوق يومى & \multirow{7}{*}{$\begin{array}{l}\text { ألقراع الأسواق } \\
\text { التجارية }\end{array}$} & & $r$ & جراج أو مخزن & \\
\hline & $r$ & سوق اسبوعى & & & $\varepsilon$ & أخرى & \\
\hline & $r$ & مول تجارى & & \multirow{4}{*}{ Ordinal } & 1 & رخام & \multirow{4}{*}{ واجهة } \\
\hline & $\varepsilon$ & سوبر ماركت & & & $r$ & جرانيت & \\
\hline & $\circ$ & محل صغير & & & $r$ & صباغة & \\
\hline & 7 & أكثر من خدمة & & & $\varepsilon$ & أخرى & \\
\hline & v & أخرى & & Scale & & & مساحة المنزل \\
\hline \multirow{5}{*}{ Ordinal } & 1 & أنوبيس نقل عام & \multirow{5}{*}{ للإهمل } & Scale & & نطقة السكن & سعر المتر فى \\
\hline & $r$ & الترام الكهربائى & & \multirow{4}{*}{ Ordinal } & 1 & أقل من · ا سنوات & \multirow{4}{*}{ المبنى عمر } \\
\hline & $r$ & سيارة أجرة & & & r & من ·1 - . r سنة & \\
\hline & $\varepsilon$ & سيارة خاصة & & & $r$ & من ·r - .0.0 سنة & \\
\hline & 0 & أخرى & & & $\varepsilon$ & أكثر من •0 سنة & \\
\hline \multirow{3}{*}{ Ordinal } & 1 & أقل من ·r دقيقة & \multirow{3}{*}{ اللوصن } & \multirow{3}{*}{ Ordinal } & 1 & الخرسانة & 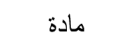 \\
\hline & r & من ·r-r. & & & r & الخشب & بناء \\
\hline & $r$ & أكثر من • ד دقيقة & & & $r$ & أخرى & الحوائط \\
\hline
\end{tabular}

Multivariate ويوضح الجدول رقم (^) نتائج اختبار المعنوية الكلية للمتغيرات المستقلة

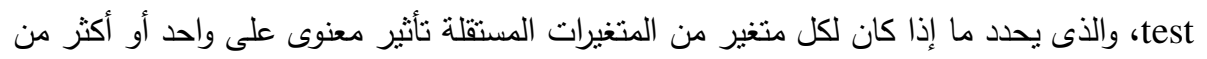

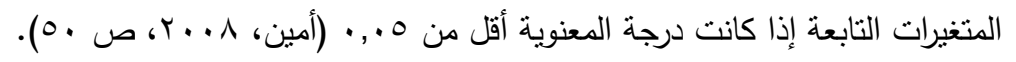


جدول (^) : اختبار Multivariate test.

\begin{tabular}{|c|c|c|c|c|}
\hline مدى وضوح التأثير & حجم التأثير & P-Value & قيمة F المحسوية & المتغيز \\
\hline., 119 &., 99. & $\cdot, Y 9 V$ & $7,7 \leq$ & النوع \\
\hline$\cdot, \varepsilon \wedge \wedge$ & $\cdot, 999$ & $\cdot, \cdot \vee V 7$ & $1 \cdot \varepsilon, 9 \cdot 1$ & محل الميلاد \\
\hline $1, \ldots$ & $\cdot, 991$ & $\cdot, \cdots 1$ & וזי,תם & الحالة الزواجية \\
\hline$\cdot, 971$ &., 910 & $\cdot, .11$ & $r, \wedge \wedge$. & محل الاقامة \\
\hline$\cdot, \wedge \cdot 1$ & $\cdot, 9 \wedge r$ & $\cdot,+4 q$ & $V, V \leq r$ & محل العمل \\
\hline $1, \ldots$ & $1, \ldots$ & ., . r & $r \wedge v, \cdot \varepsilon q$ & مستوى التعليم \\
\hline $1, \ldots$ & $\cdot, 999$ & $\cdot, \cdots$ & 114,970 & اللغات \\
\hline$\cdot, \wedge r \leq$ & $1, \ldots$ & $\cdot, \cdot r V$ & $\varepsilon \varepsilon q, 1 \vee V$ & طبيعة العمل \\
\hline$\cdot, 9 \curlyvee 9$ & $\cdot, 90 \leqslant$ & $\cdot, \cdot 1 \leq$ & $\varepsilon, 11 V$ & متوسط حجم الاسرة \\
\hline $1, \ldots$ & $\cdot, 9 \cdot 7$ & ת משי, & $\varepsilon, r q q$ & 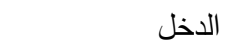 \\
\hline
\end{tabular}

وقد أظهر فحص وتحليل البيانات فى جدول (^) أن درجة المعنوية قد سجلت أقل من ه.,.

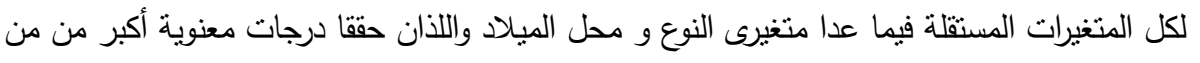

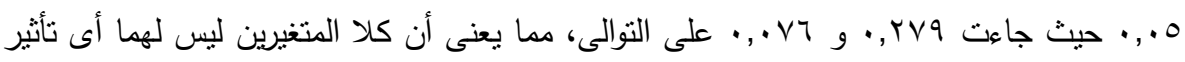

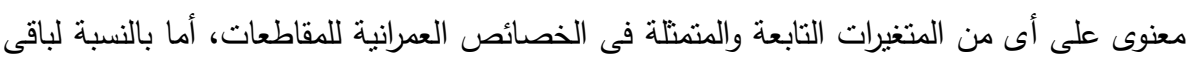

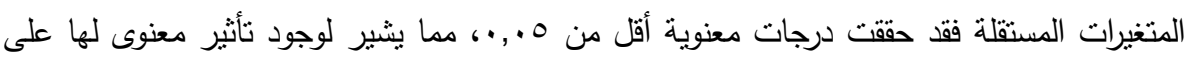

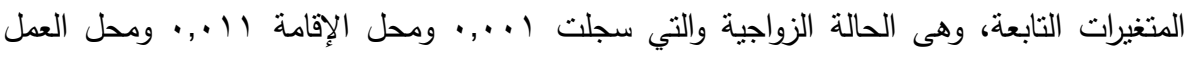

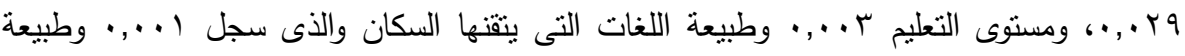

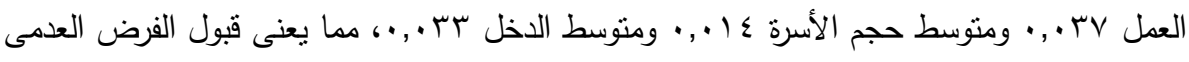

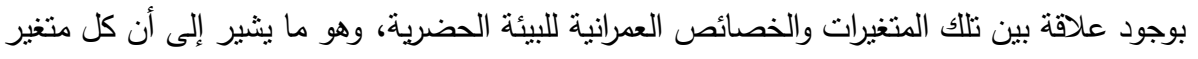

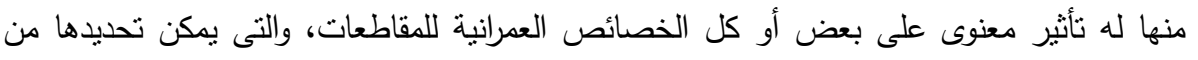
خلال تحليل التباين والذى يبين أى من المتغيرات التابعة يتأثر بأى من المتغيرات المستئلة.

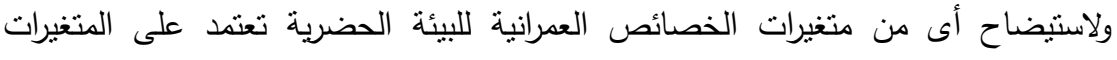

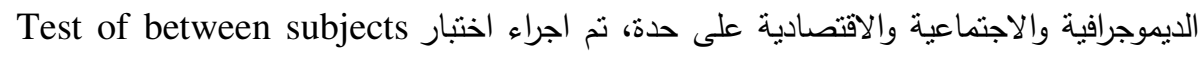
effects

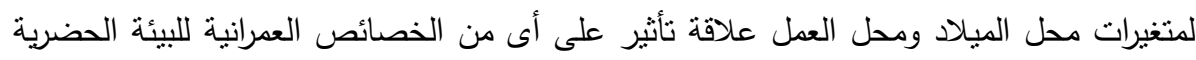

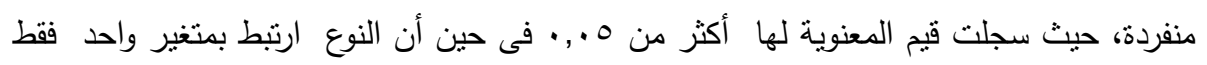
هو عدد الطوابق فى المبنى حيث سجل قيم معنوية 17 ه ., . 


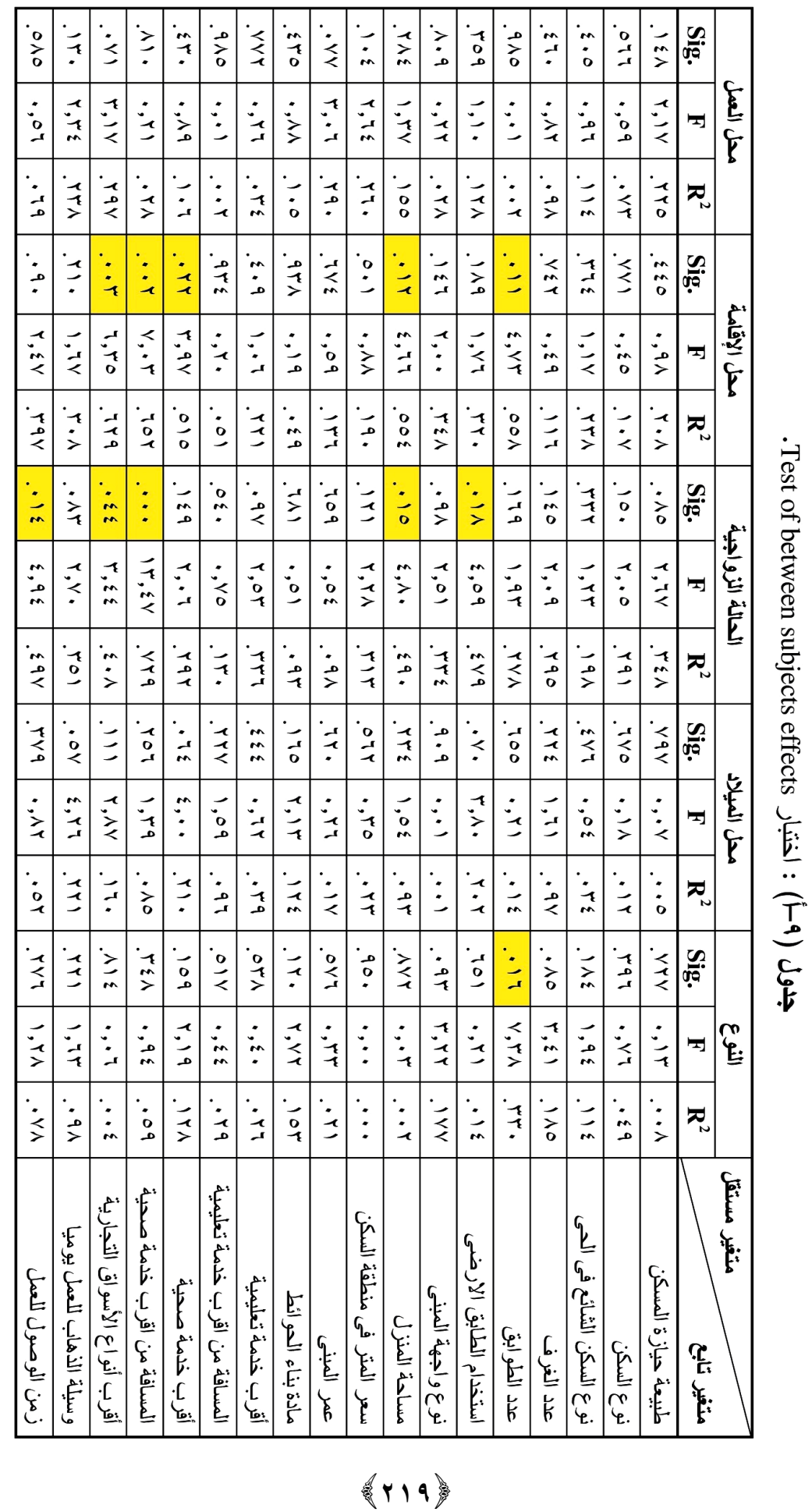


وقد أظهر تحليل البيانات ارتباط متغير الحالة الزواجية بخمس خصائص عمرانية هى مساحة

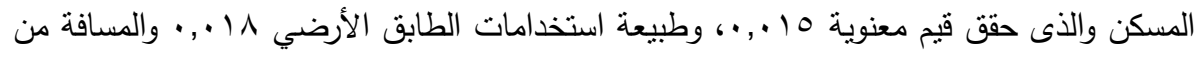

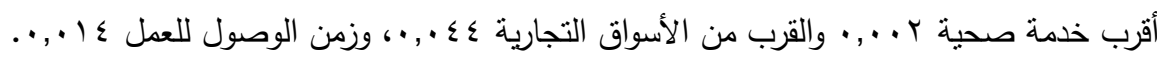

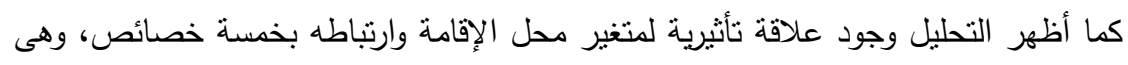

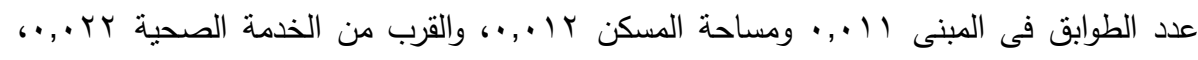

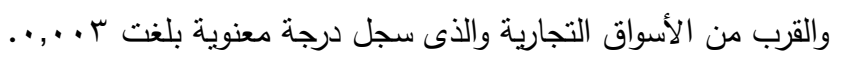

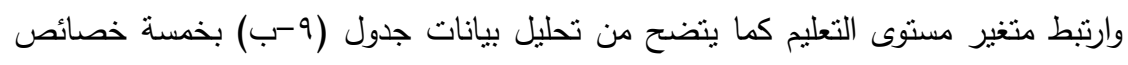

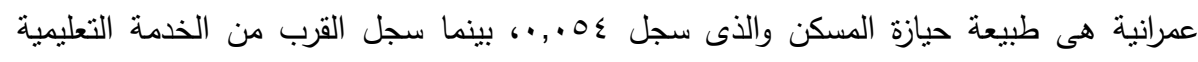

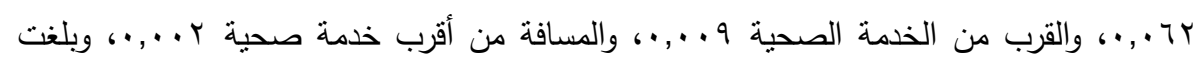

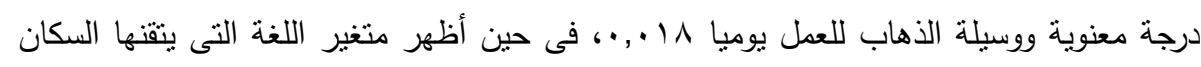

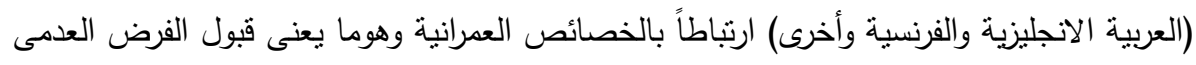

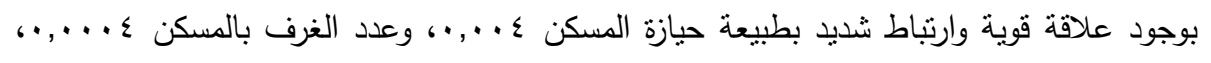

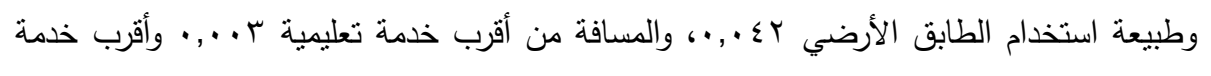

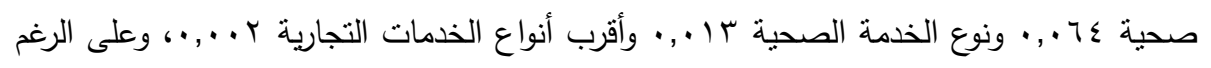

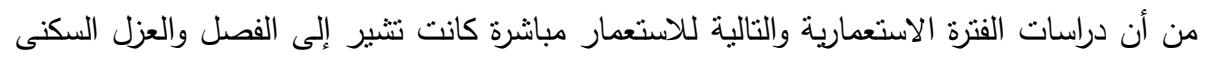

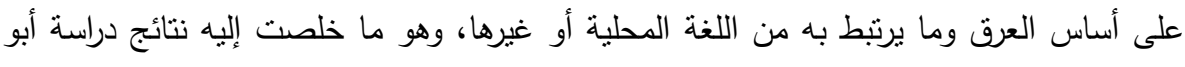
لغد فى (·A1) حيث انتهت إلى أن ممارسات الفصل العرقي والعنصري داخل المدينة المغربية

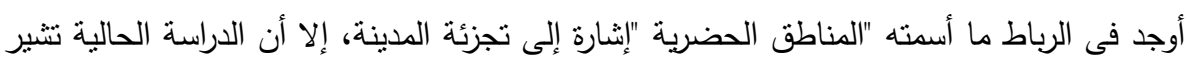

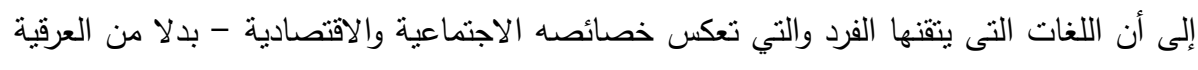

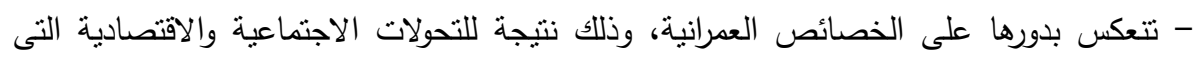

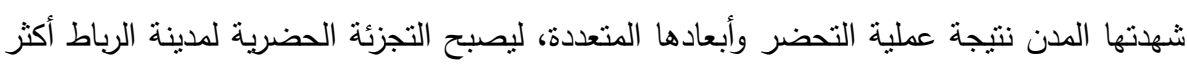
ارتباطاً بالطبقية الاقتصادية ومفرداتها.

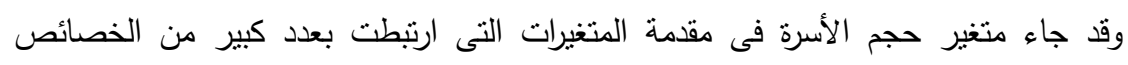

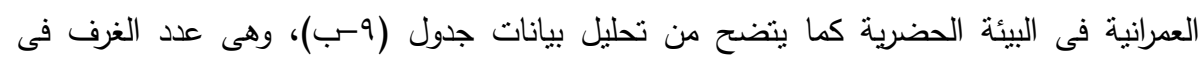

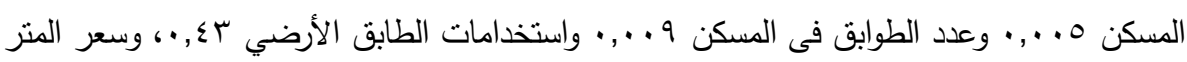

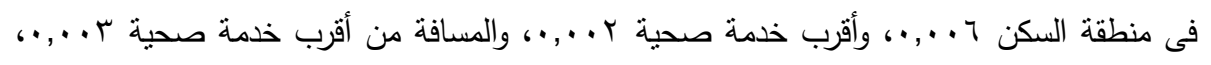

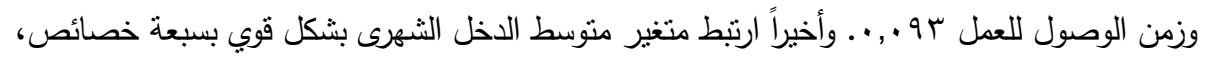

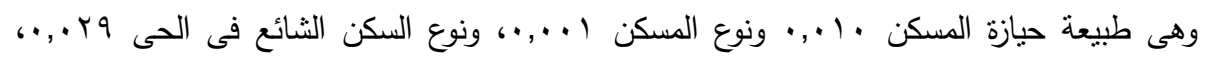

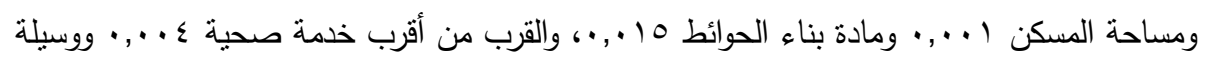




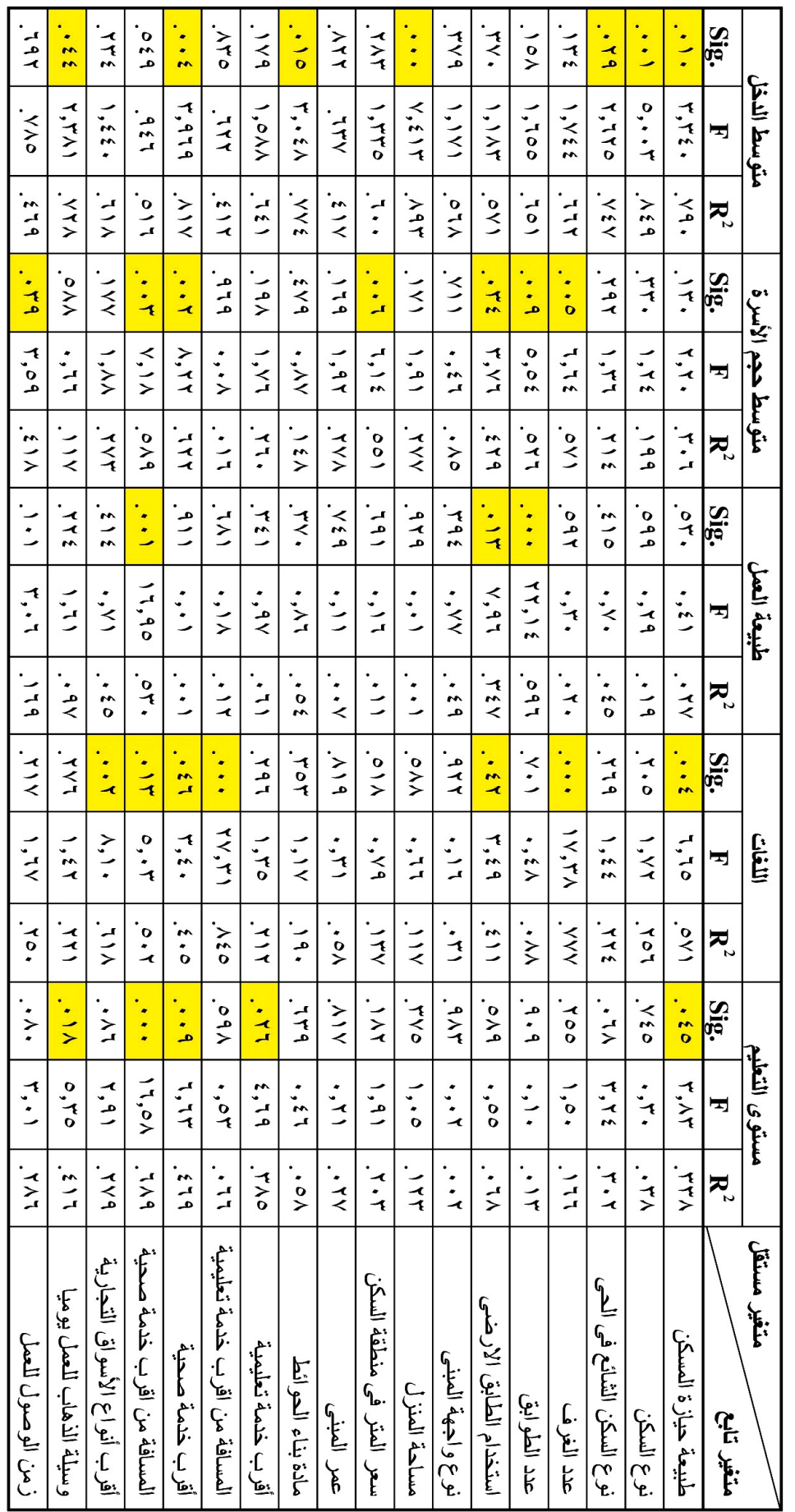


الذهاب إلى العمل ع . ., . وبذلك يحدد دخل الأسرة بشكل متزايد طبيعة تقسيم المدينة فى نمط أنثبه

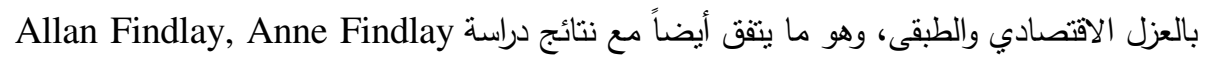

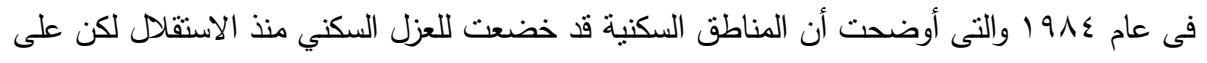
أساس الدخل بدلاً من العرق (Findlay \& Paddison, 1984, p. 51). ويتضح من تحليل نتائج الاختبارات السابقة أن أكثر المنغيرات المستقلة (الديموجرافية والاقتصادية والاجتماعية) تأثيراً فى متغيرات التركيب العمرانى تنثلت فى متغيرات (محل الاقامة -

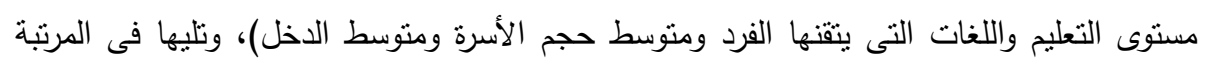

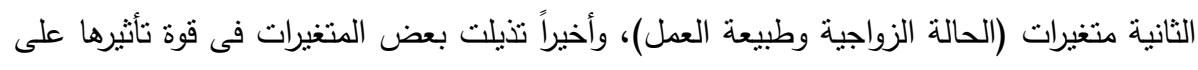

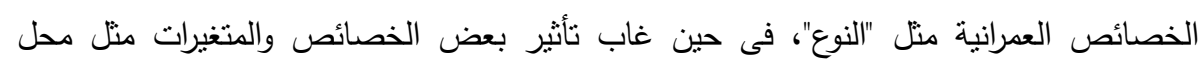

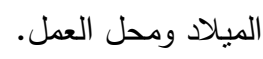

وتباين فى المقابل تأثز المتغيرات التابعة و التى تمنلها خصائص التركيب العمرانى، حيث جاءت فى المرتبة الأولى متغيرات (القرب من الخدمات الصحية وطبيعتها، عدد الطوابق، وطبيعة استخدام الطابق الأرضى) وتلاها فى المرتبة الثانية (طبيعة حبازة والقرب من الأسواق التجارية)،

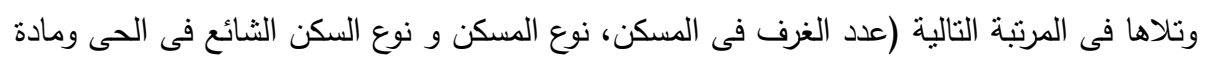
بناء الحوائط)، وتذيلت متغيرات (سعر المتر فى منطقة السكن والقرب من خدمة نعليمية) فى نأثرها

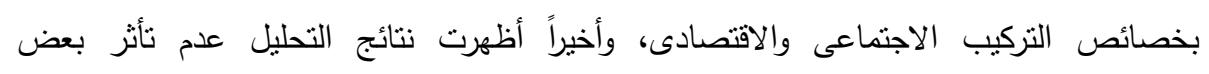
الخصائص العمرانية بالخصائص الاقتصادية والاجتماعية وهى (طبيعة الطرق فى الحى و مادة بناء

$$
\text { الأسقف ونوع واجه المبنى وعمر المبنى). }
$$

وتعد التفاوتات المكانية وتجزئة المدن لمناطق حضرية منمايزة هى سمة لصنئ لصيقة بالمدن خاصة دول

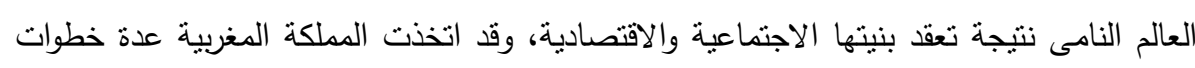

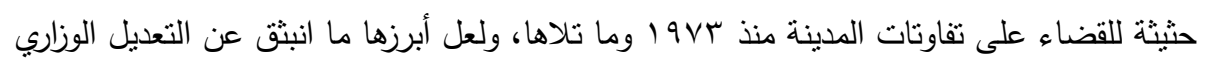

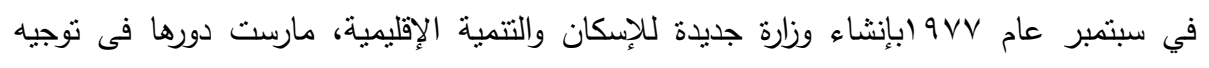

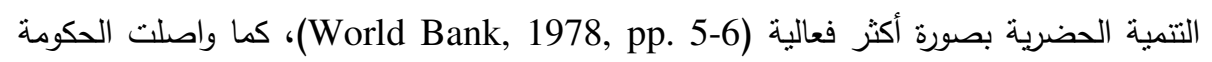

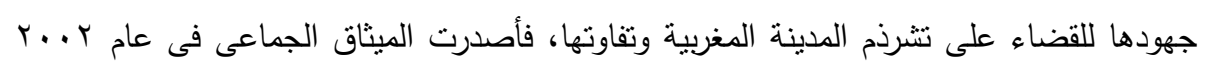

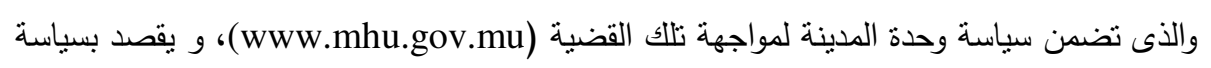

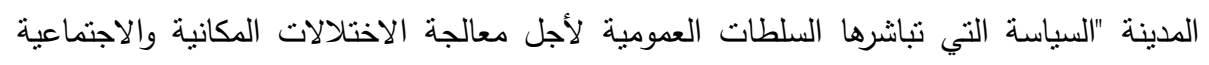

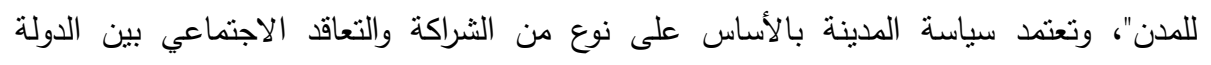
بقطاعاتها المختلفة والجماعات المحلية والقطاع الخاص والمجنمع المدني فى تنفيذ مشارئ مناريع محددة

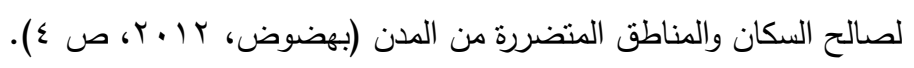


وقد تم فى إطار المبادرة الوطنية للتتمية البشرية، إنجاز آب مشروعاً على مستوى مدينة الرباط

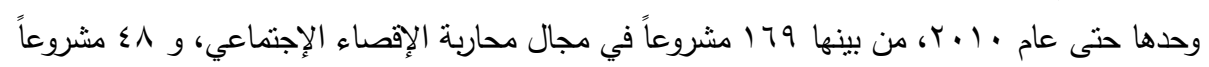

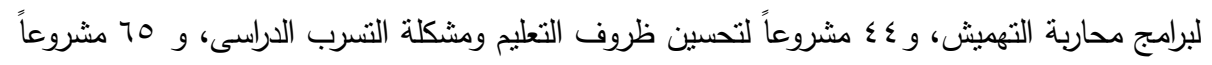

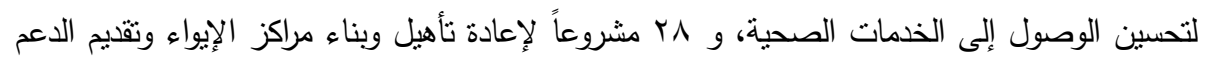

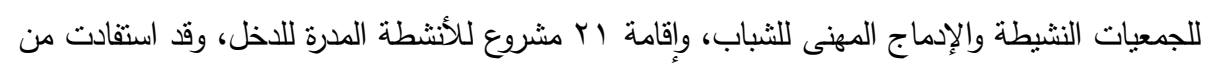

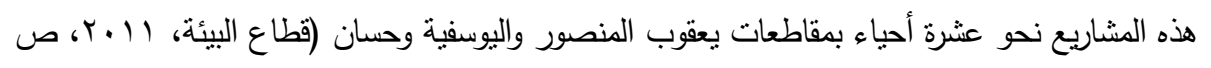
r.r.r)، وعلى الرغم من ذلك افقد اقتصر اهتمام سياسة المدينة في البداية بمناطق أو أحياء محددة،

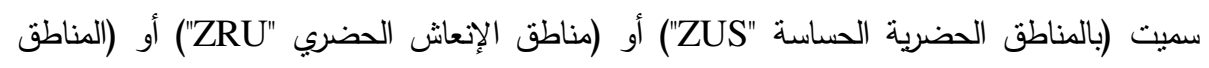

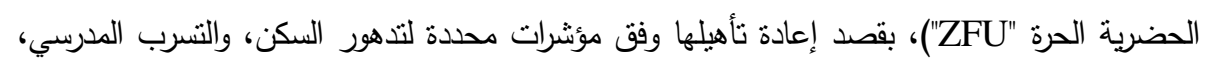

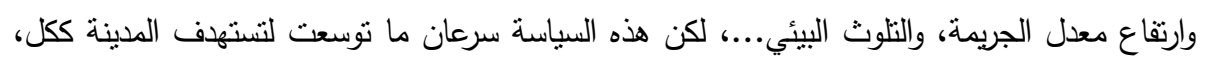

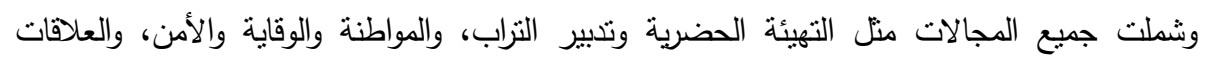

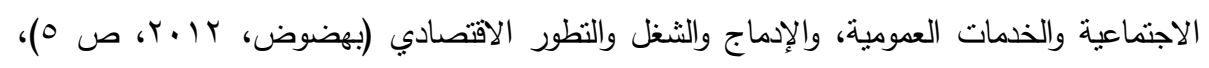

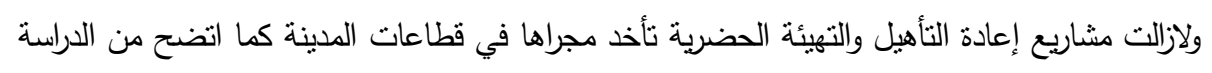

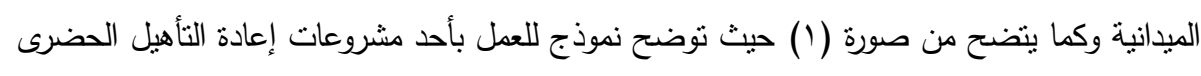
لأحد المؤسسات النعليمية والثقافية وهو "مركز التقتح النقافى والفنى" فى حئ حئ المحيط بمقاطعة حسان.
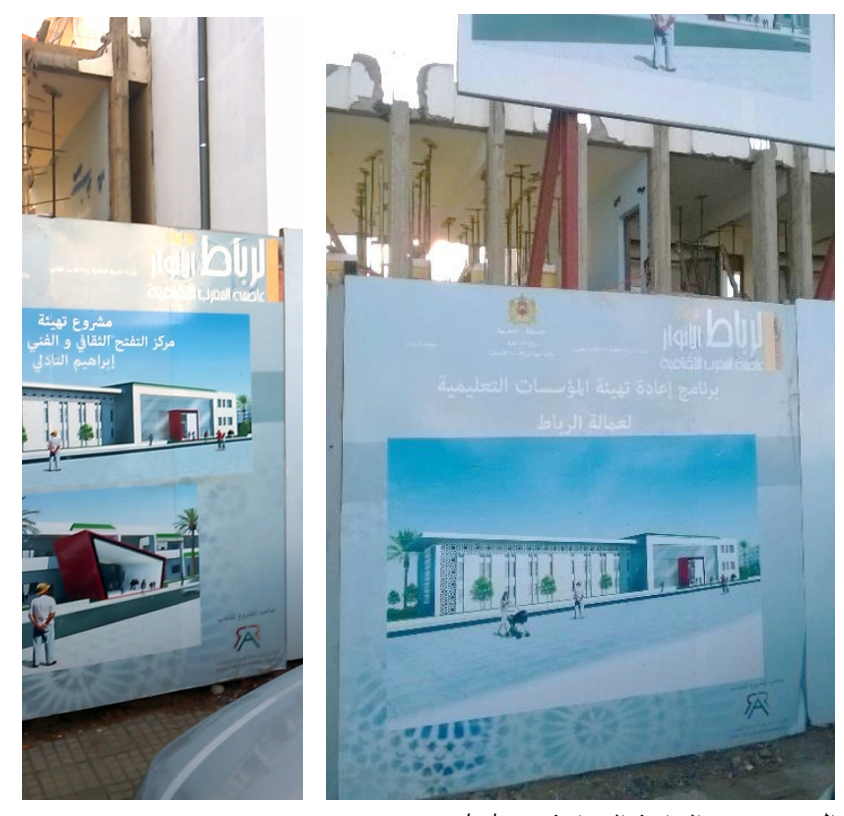

المصدر: من الدراسة الميدانية - 10/0/ •r.

صورة (1) : نموذج لمشاريع إعادة التأهيل والتهيئة الحضرية فى حى المى المحيط بمقاطعة حسان.

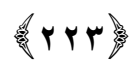


وبالرغم من أن نلك السياسات الحضرية المتبعة فى المغرب منذ بداية العشرية الأولى للألفية

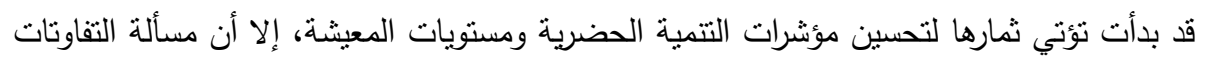

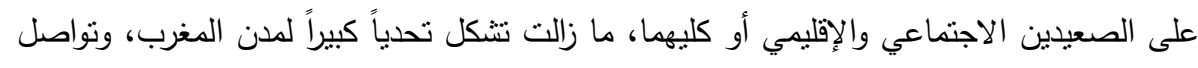

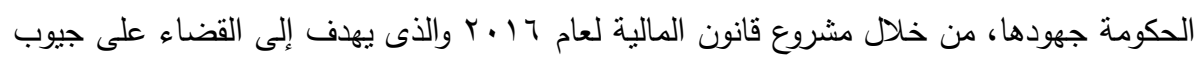

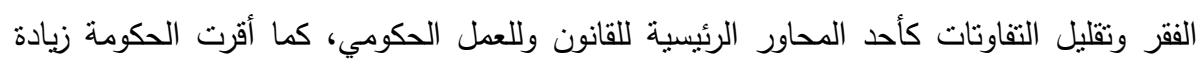

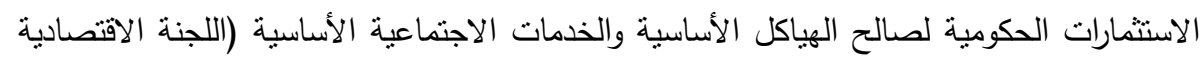

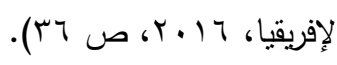

\section{خاهساً - النتائج والتوصيات :}

* أظهرت الدراسة أنه على الرغم من الاتصال المكانى بين قطاعات المدينة إلا أنه يوجد بينها

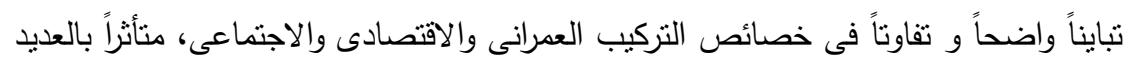

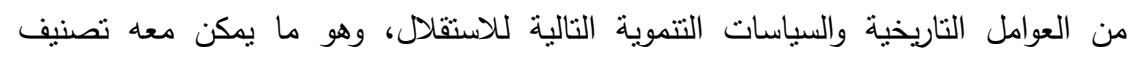
مقاطعات المدينة إلى فئتين أو أكثر طبقاً لمدى تقارب أو تجانس وتتافر الخصائص لتصن كلها.

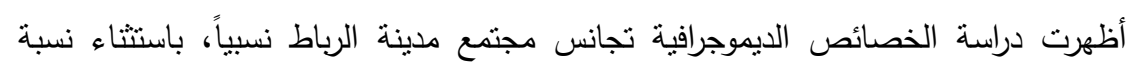
التركيب العمرى ومعدلات الخصوبة التى أظهرت اختلافاً طفيفاً بين مقاطعات المدينة. * أظهرت دراسة الخصائص الاقتصادية والاجتماعية عدم تجانس مجتمع مدينة الرباط نسبياً،

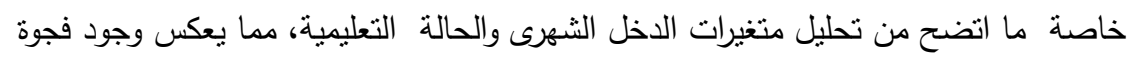
في المستوى الاقتصادى والاجتماعى.

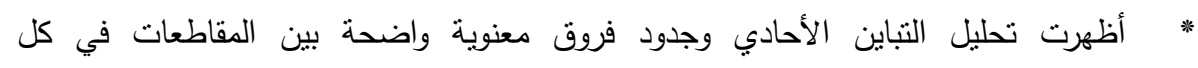

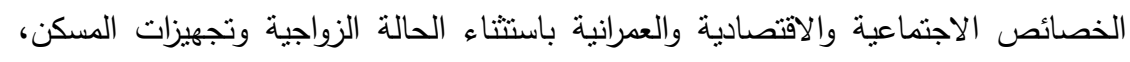

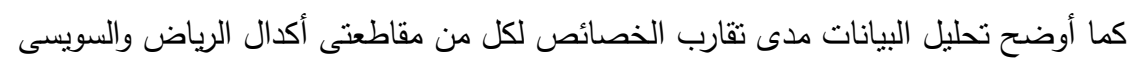
في مقابل تقارب الخصائص بين مقاطعتى البوسفية ويعقوب المنصور بشكل أساسى.

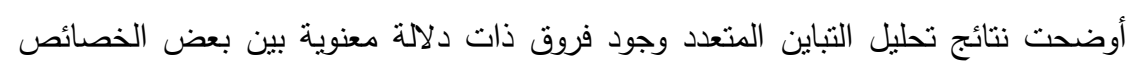

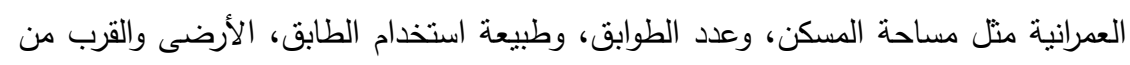

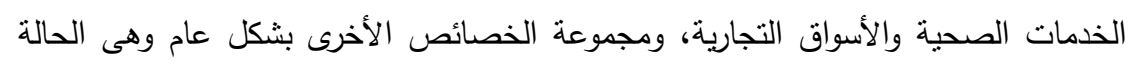

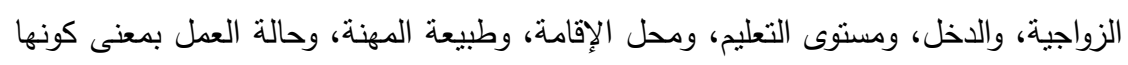

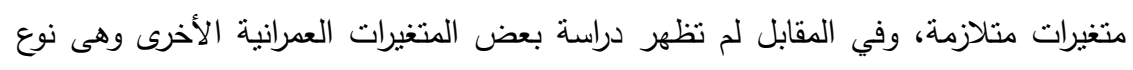

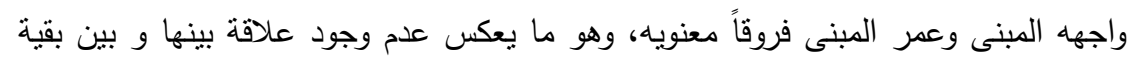
المتغيرات بمعنى كونها متغيرات تتسم بالاستقلالية. 
اتضح من الدراسة وجود علاقة مباشرة بين الخصائص العمرانية والاجتماعية والاقتصادية

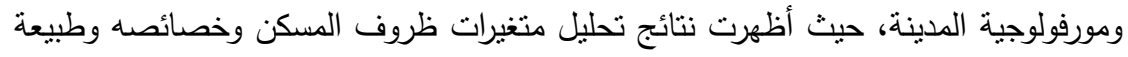
المهنة والعمل، وجود علاقة مباثرة لها مع مورفولوجية الددينة وتطورها التاريخى. خلصت الدراسة إلى أن وجود علاقة تأثير متبادل بين بعض جوانب التركيب العمرانى والاقتصادى والاجتماعى نتج عن تفاعلها إضفاء سمات وملامح تركيبية عمرانية واجتماعية لقطاعات المدينة نتج عنها تجزئتها مكانياً لوحدات حضرية منباينة، وهو ما يؤكد نتائج تحليل التباين الأحادى بما أوضحته من نباين ببين المقاطعات.

من خلال ما سبق تبين أن مدينة الرباط تتمتع بخصائص عمرانية وديموجرافية واقتصادية

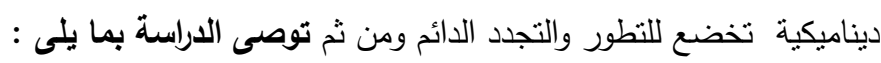

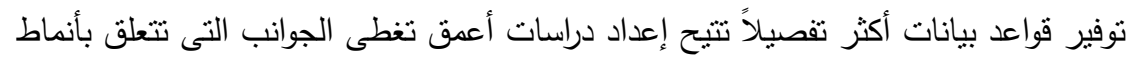

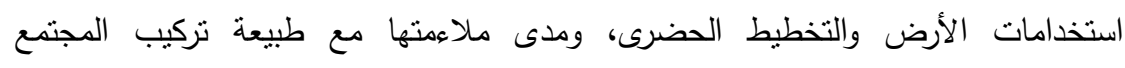
وخصائصده، والتوزيع الجغرافي والتحليل المكانى للمرافق والخدمات وعلاقتها بتحولات النسيج الحضري الاجتماعي. قدمت الدراسة الحالية صورة أولية عن تفاوت مقاطعات المدينة، ويتعين طبقاً لما خلصت إليه من نتائج تدخل الدوائر الرسمية المسؤولة عن التخطيط والإدارة الحضرية بقدر ما يتوافر من فئن بيانات رسمية وميدانية.

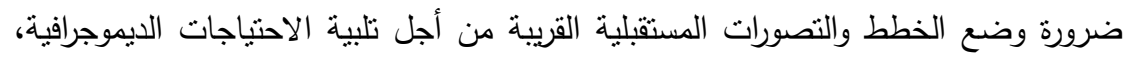

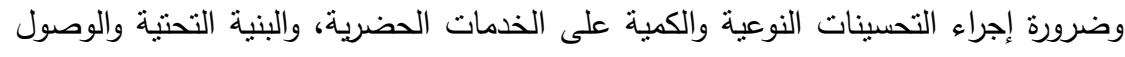

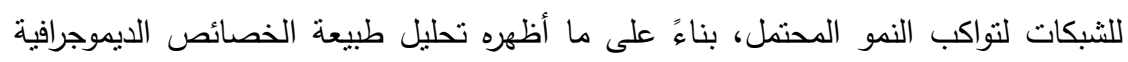
والاجتماعية والاقتصادية مجتمعة. تفعيل العمل بسياسة وحدة المدينة التى صدرت مع الميثاق الجماعى لسنة ب . . r، وهدفت

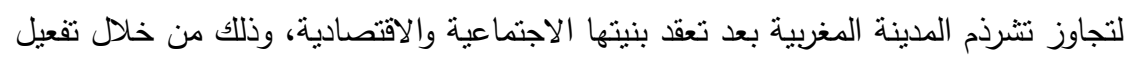
اللامركزية وتفعيل المشاركة المحلية في التخطيط الحضري، من أجل تحقيق هدف المدينة المدمجة المتجانسة أو غير المجزأة، فكما أن الددن مجالات لانتشار ظواهر الإلفيط الإقصاء وانعدام المساواة، هى أيضاً مواقع استراتيجية للتغيير والتتمية. 


\section{ملحق (1)}

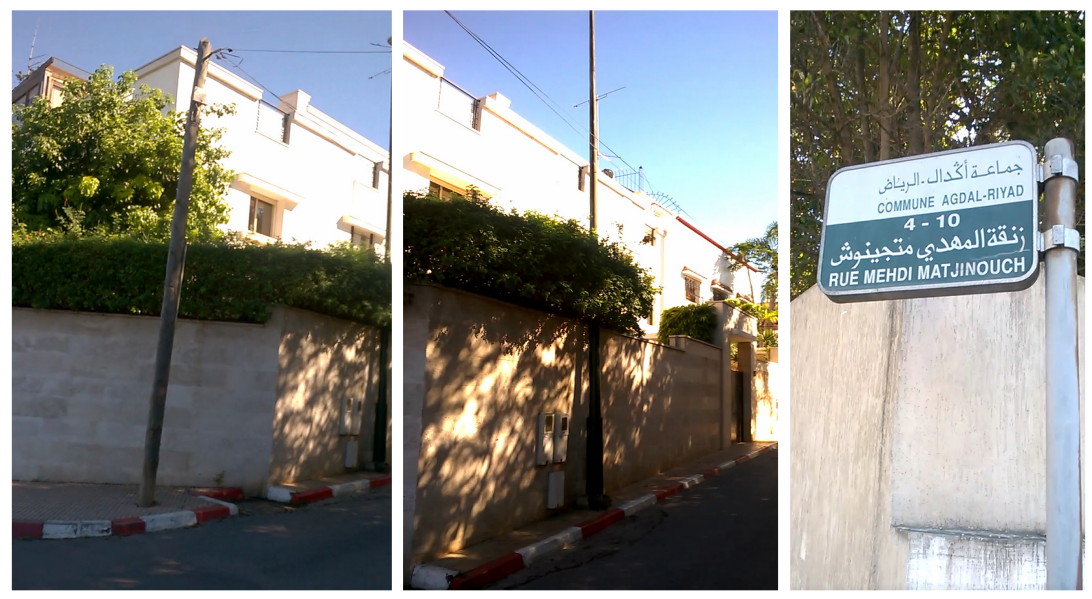

(أ ) بانوراما نمط الإسكان "الفيلات" بمقاطعة أكدال الرياض.
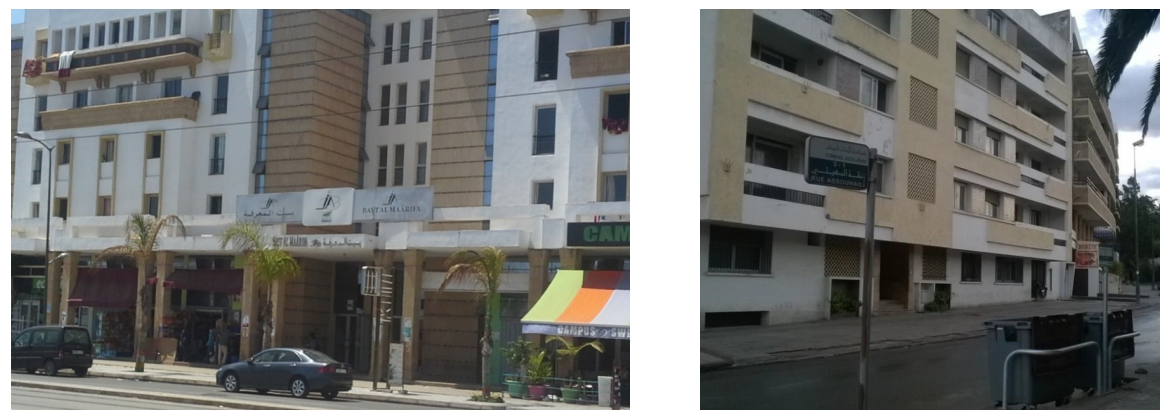

$$
\text { (ج) نموذج الاسكان الجماعى (بيت المعرفة) }
$$$$
\text { (ب) نمط مسكن الثقق فى أكدال الرياض }
$$

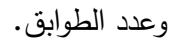

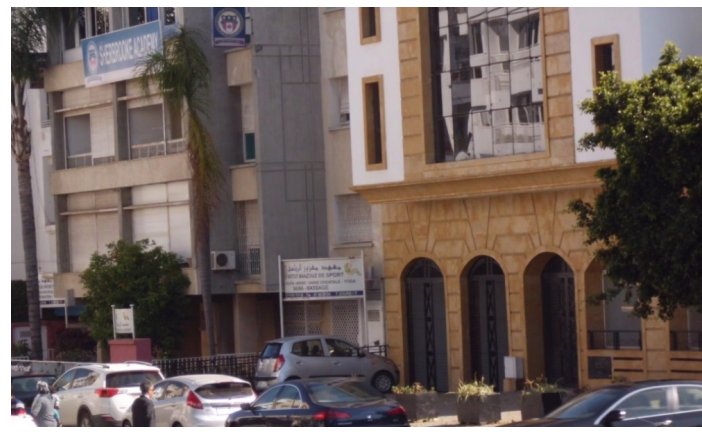

$$
\begin{aligned}
& \text { (د) نمط واجهات الجرانيت فى يعقوب المنصور • } \\
& \text { المصدر: من الباحثة، الدراسة الميدانية خلال الفترة ابريل VY-Y مايو } 10 \text { ـr. } \\
& \text { 鼻Yry }
\end{aligned}
$$




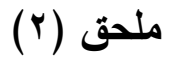
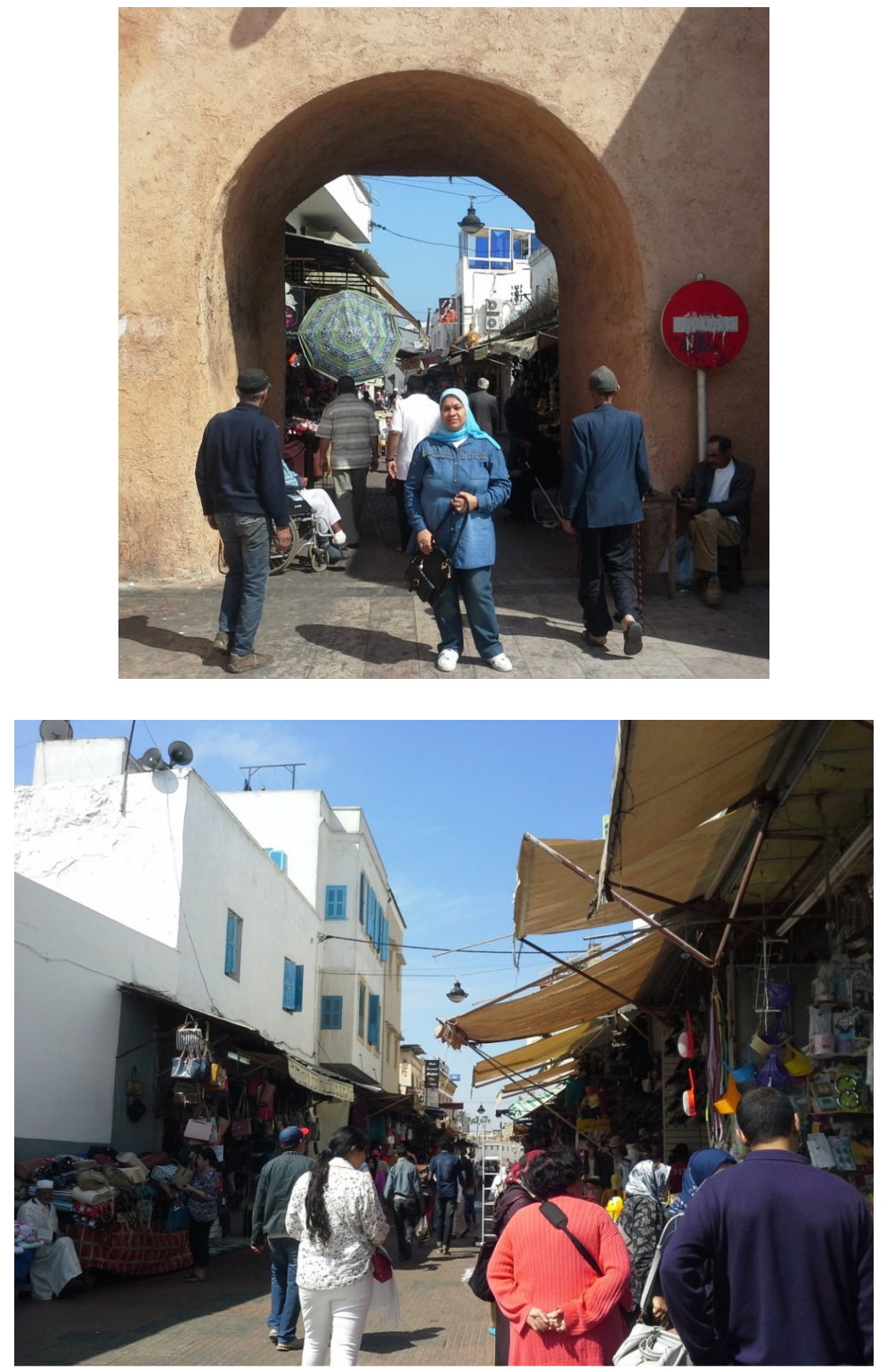

بعض عناصر مورفولوجية المدينة القديمة (السور ، الثوارع الضيقة / المساكن)،

عدد الطوابق ونوع واجهات الصباغة فى المدينة العتيقة (ثنارع السويقة)

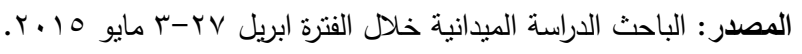

受rrV管 


\section{ملحق (ץ) : استمارة استبيان}

مدينة الرياط - دراسة تحليلية لبعض خصائص التركيب العمرانى والسكانى

وهى للبحث العلمى فقط

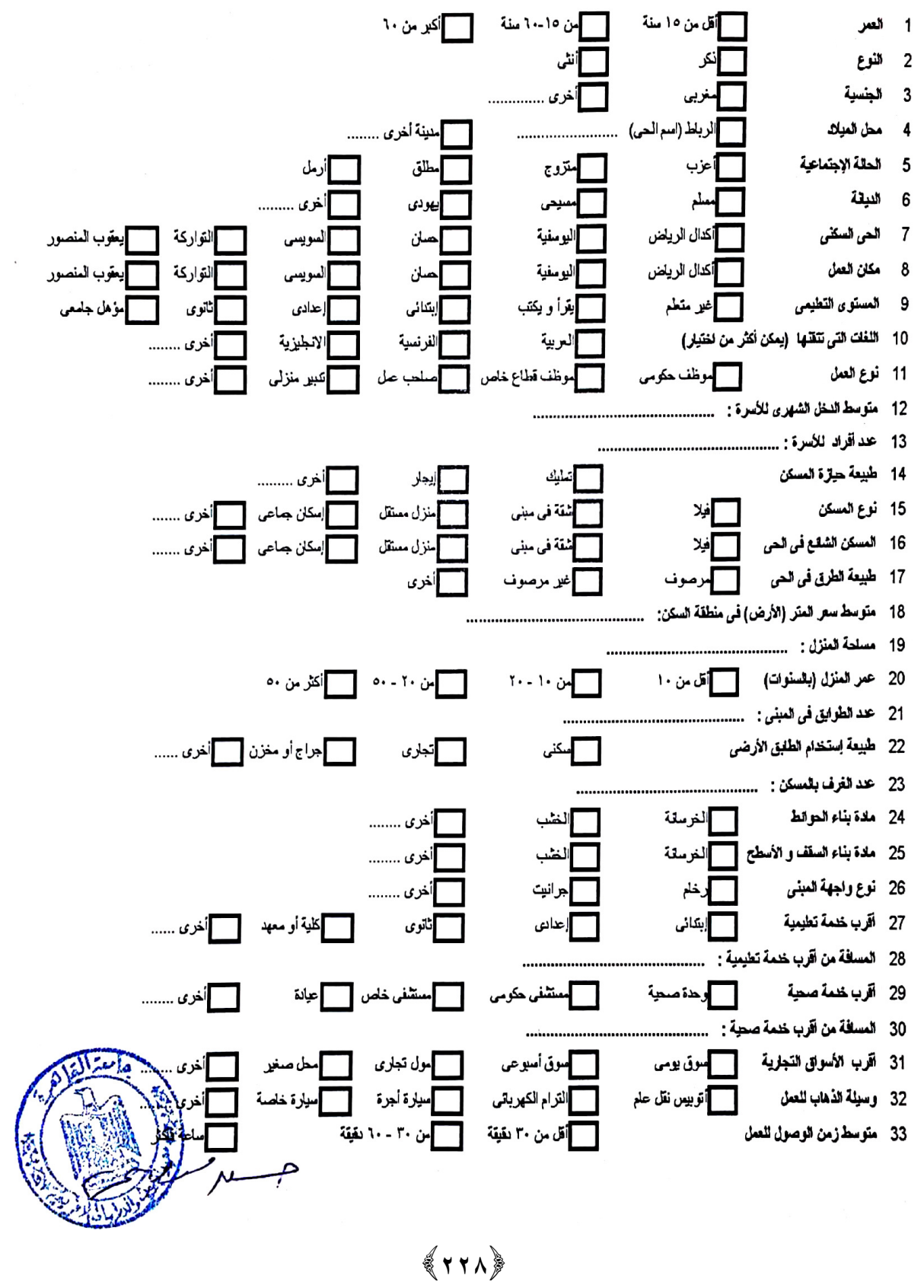




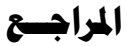

أولاً : المراجع العربية.

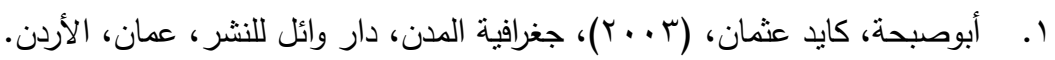

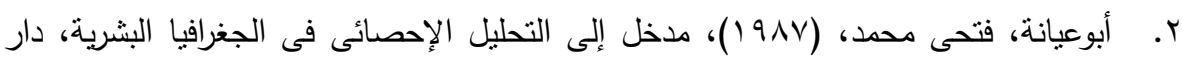
المعرفة الجامعية، الإسكندرية.

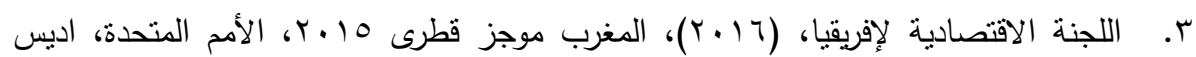
أبابا، اثيوبيا.

ع. أمين، أسامة ربيع، (1 . . ب)، التحليل الإحصائى للمتغيرات المتعددة باستخدام برنامج SPSS، .https://www.kutub.info/library/book/5776

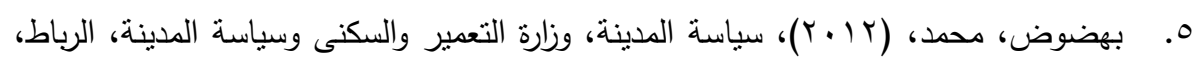

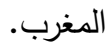

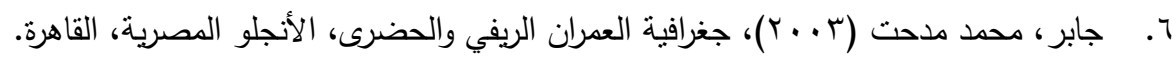

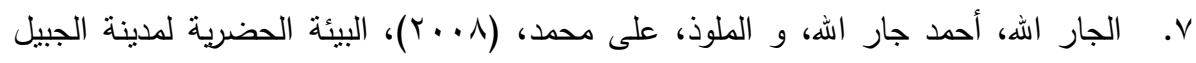

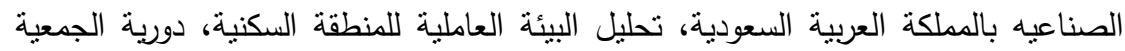
الجغرافية الكويتية، العدد، بسا، الكويت.

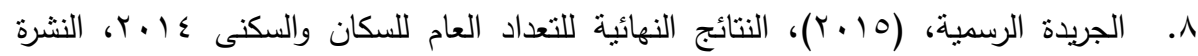

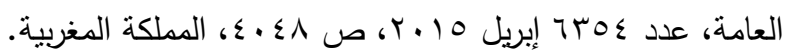

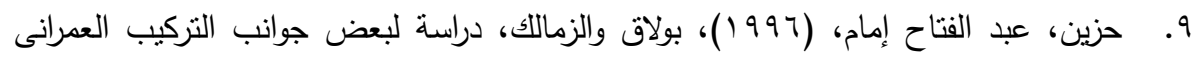

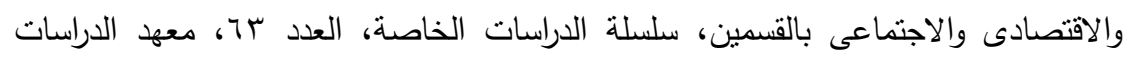
العربية، القاهرة.

• (ا. حمدان، جمال، (991 (1)، القاهرة، الهيئة المصرية العامة للكتاب، القاهرة.

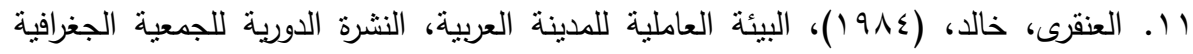

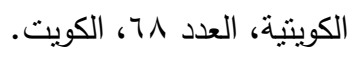

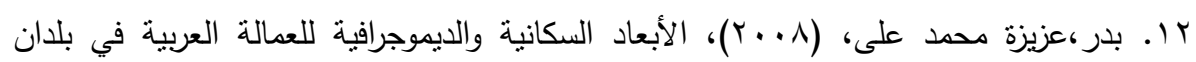

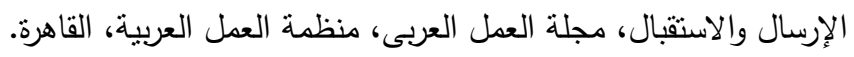

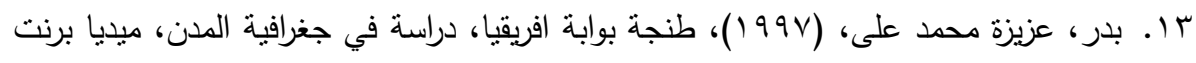
الصفوة للطباعة، القاهرة. ع ا. غلاب، محمد السيد، و يسرى الجوهرى، (9VY)، جغرافية الحضر، منشأة المعارف، الاسكندرية. 


$$
\begin{aligned}
& \text { 10. قطاع البيئة، (1) (Y)، تقرير حول الحالة البيئية لجهة الرباط - سلا - زمور - زعير، وزارة } \\
& \text { الطاقة والمعادن والمباه والبيئة، الرباط، المملكة المغربية. }
\end{aligned}
$$

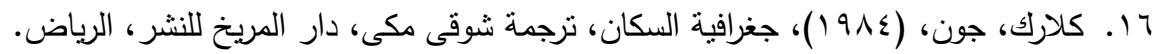

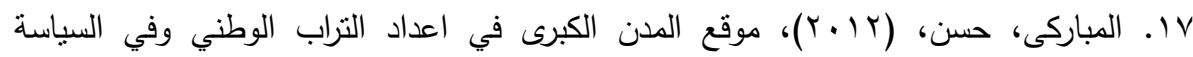

$$
\begin{aligned}
& \text { الجهوية بالدغرب، مجلة كلية الآداب والعلوم الإنسانية، جامعة القاضي عياض، مراكث. }
\end{aligned}
$$

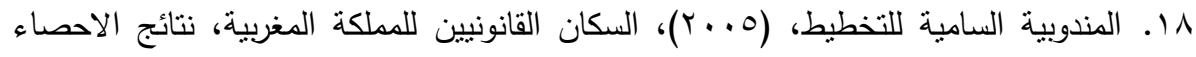

$$
\begin{aligned}
& \text { العام للسكان والسكنى ع . . بـ، المملكة المغربية. } \\
& 9 \text { 1. المندوبية السامية للتخطيط، (ع (ب)، الاحصاء العام للسكان والسكنى، النتائج الأولية }
\end{aligned}
$$

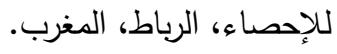

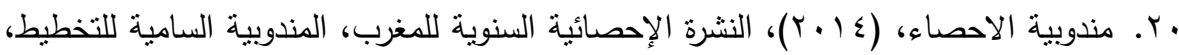

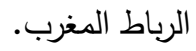

http://rgphentableaux.hcp.ma/Default1 الr المندوبية السامية للتخطيط

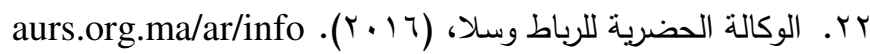

\section{ثانياً : المراجع غير العربية.}

23. Abdel-Azeem, H.S. (2013), Wadi Elnatroun Town, A Geostatistical Analysis of Urban and Sociodemographic Characteristics, Bulletin of the Egyptian Geographical Society, Vol. 86.

24. Abu-Lughod, J. (1975), The Legitimacy of Comparisons in Comparative Urban Studies, A Theoretical Position and an Application to North African Cities. Urban Affairs Quarterly, Vol. 11, No. 1.

25. Balbo, M., \& Bouchanine, F.N. (1995), Urban Fragmentation as a Research Hypothesis: Rabat-Sale Case Study, Habitat Intl. Vol. 19, No. 4.

26. Balbo, M. (1993), Urban Planning and the fragmented city of Developing Countries, Third World Planning Review, 15(1).

27. Boateng, S., et al., (2016), Comparative Analysis of Households Solid Waste Management in Rural and Urban Ghana, Journal of Environmental and Public Health, Article ID 5780258.

28. Chatterjee, L. (1989), Third World cities, In N.T. Richard Peet, New Models in Geography, The Political Economy Perspective, London, Taylor \& Francis Group.

29. Findlay, A.M., \& Paddison, R. (1986), Planning the Arab City The Cases of Tunis and Rabat, Progress in Planning, Vol. 26, pp. 1-82.

30. Findlay, A.M., \& Paddison, R. (1984), Maintaining the Status Quo: An Analysis of Social Space in Post-Colonial Rabat, Urban Studies 21, 41-51.

$$
\text { 叠rr.危 }
$$


31. Gomeaz, B., \& Gones, P. (2010), Research Methods in Geography, A Critical Introduction, First Edition, Wiley, USA.

32. Johnson, J.H. (1972), Urban Geography, An Introductory Analysis, Second Edition, Library of Congress, New York.

33. Sabina, M., \& Ruiz, L. (2016), Analysing Relationships Between Urban Land Use Fragmentation Metrics And Socio-Economic Variables, The International Archives of the Photogrammetry, Remote Sensing and Spatial Information Sciences, ISPRS Congress.

34. Urry, J. (1989), Sociology and geography, In N.T. Richard Peet, New Models in Geography The Political-Economy Perspective (p. 295), Taylor \& Francis Group, London.

35. World Bank, (1978), Kingdom of Morocco, Rabat Urban Development Project. 


\title{
Rabat City \\ An Analytical Study of Some Urban and Population Structural Characteristics
}

\begin{abstract}
The study of urban space and the analysis of its components seek to identify planning determinants to achieve homogeneity among city divisions, and to reduce the structural urban dualism in all its aspects, not only morphological, but the disparities of access to services and variations in population socioeconomic characteristics. This helps in eliminating city fragmentation, to reach the highest level of homogeneity in the cities and the creation of a sustainable urban environment.

The study aims to investigate urban fragmentations and inequalities by testing the similarities and differences among the major administrative divisions of "Rabat" the capital of Morocco, in terms of social, economic, and urban characteristics according to the 2014 population and housing census of results. This is achieved by applying the geostatistical comparative Analysis of variance "ANOVA" to check wither there are significant differences among the six communes of the city in the mentioned characteristics. Furthermore, the relation between socioeconomic and urban space characteristics is examined by applying Multivariate Analysis of Variance "MANOVA" to identify which of the socioeconomic characteristics affect significantly one or more of urban space characteristics. MANOVA technique is applied on a field survey that systematically sampled houses from which 400 households and respondents were randomly selected to fill the shortcomings in the available census results. The IBM SPSS statistics 23 is used for applying either ANOVA or MANOVA techniques.

It is found that, there exist spatial disparities among the city communes in terms of socioeconomic and urban space characteristics. Moreover, the city communes can be classified into heterogeneous groups that are similar within each group. On the other hand the majority of socioeconomic characteristics are found to have significant effect on urban space characteristics among the city communes. Thus the study recommends keeping on supporting less developed parts of the city to reach the spatial homogeneity adopted by Morocco since independence.
\end{abstract}

Key Words: Urban socioeconomic characteristics, ANOVA, MANOVA, urban fragmentation.

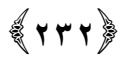

